\title{
Atmospheric pollution over the eastern Mediterranean during summer - a review
}

\author{
Uri Dayan $^{1}$, Philippe Ricaud ${ }^{2}$, Régina Zbinden ${ }^{2}$, and François Dulac ${ }^{3}$ \\ ${ }^{1}$ Department of Geography, The Hebrew University of Jerusalem, Jerusalem, Israel \\ ${ }^{2}$ CNRM, Météo-France, CNRS UMR3589, Toulouse, France \\ ${ }^{3}$ Laboratoire des Sciences du Climat et de l'Environnement (IPSL-LSCE), CEA-CNRS-UVSQ, Univ. Paris-Saclay, \\ Gif-sur-Yvette, France
}

Correspondence to: Uri Dayan (msudayan@mscc.huji.ac.il)

Received: 29 January 2017 - Discussion started: 30 March 2017

Revised: 27 September 2017 - Accepted: 1 October 2017 - Published: 8 November 2017

\begin{abstract}
The eastern Mediterranean (EM) is one of the regions in the world where elevated concentrations of primary and secondary gaseous air pollutants have been reported frequently, mainly in summer. This review discusses published studies of the atmospheric dispersion and transport conditions characterizing this region during the summer, followed by a description of some essential studies dealing with the corresponding concentrations of air pollutants such as ozone, carbon monoxide, total reactive nitrogen, methane, and sulfate aerosols observed there.

The interlaced relationship between the downward motion of the subsiding air aloft induced by global circulation systems affecting the EM and the depth of the Persian Trough, a low-pressure trough that extends from the Asian monsoon at the surface controlling the spatiotemporal distribution of the mixed boundary layer during summer, is discussed. The strength of the wind flow within the mixed layer and its depth affect much the amount of pollutants transported and determine the potential of the atmosphere to disperse contaminants off their origins in the EM. The reduced mixed layer and the accompanying weak westerlies, characterizing the summer in this region, led to reduced ventilation rates, preventing an effective dilution of the contaminants. Several studies pointing at specific local (e.g., ventilation rates) and regional peculiarities (long-range transport) enhancing the build-up of air pollutant concentrations are presented.

Tropospheric ozone $\left(\mathrm{O}_{3}\right)$ concentrations observed in the summer over the EM are among the highest over the Northern Hemisphere. The three essential processes controlling its formation (i.e., long-range transport of polluted
\end{abstract}

air masses, dynamic subsidence at mid-tropospheric levels, and stratosphere-to-troposphere exchange) are reviewed. Airborne campaigns and satellite-borne initiatives have indicated that the concentration values of reactive nitrogen identified as precursors in the formation of $\mathrm{O}_{3}$ over the EM were found to be 2 to 10 times higher than in the hemispheric background troposphere. Several factors favor sulfate particulate abundance over the EM. Models, aircraft measurements, and satellite-derived data have clearly shown that sulfate has a maximum during spring and summer over the EM. The carbon monoxide (CO) seasonal cycle, as obtained from global background monitoring sites in the EM, is mostly controlled by the tropospheric concentration of the hydroxyl radical $(\mathrm{OH})$ and therefore demonstrates high concentrations over winter months and the lowest concentrations during summer when photochemistry is active. Modeling studies have shown that the diurnal variations in $\mathrm{CO}$ concentration during the summer result from long-range $\mathrm{CO}$ transport from European anthropogenic sources, contributing 60 to $80 \%$ of the boundary-layer $\mathrm{CO}$ over the EM. The values retrieved from satellite data enable us to derive the spatial distribution of methane $\left(\mathrm{CH}_{4}\right)$, identifying August as the month with the highest levels over the EM. The outcomes of a recent extensive examination of the distribution of methane over the tropospheric Mediterranean Basin, as part of the ChemistryAerosol Mediterranean Experiment (ChArMEx) program, using model simulations and satellite measurements, are coherent with other previous studies. Moreover, this methane study provides some insight into the role of the Asian monsoon anticyclone in controlling the variability of $\mathrm{CH}_{4}$ pollu- 
tant within mid-to-upper tropospheric levels above the EM in summer.

\section{Introduction}

The relationship between atmospheric air pollutant concentrations and large-scale atmospheric circulation systems has been examined over the past decades (e.g., Davis and Kalkstein, 1990; Dayan et al., 2008). This strong relationship and its issuing dispersion condition at several scales, and climatically related variables such as air pollutants, is presented in this work as part of the Chemistry-Aerosol Mediterranean Experiment (ChArMEx; http://charmex.lsce.ipsl.fr).

However, a first major drawback in attributing air pollutant concentrations to variations in large-scale atmospheric circulation arises from the fact that changes in removal processes and upwind emissions are not necessarily concurrent with variations in circulation. Some efforts were undertaken, mainly through coupled chemistry-climate models, to treat and analyze at the same time the changes in general circulation and atmospheric chemistry (Hein et al., 2001; Dastoor and Larocque, 2004). Moreover, secondary pollutants such as tropospheric ozone $\left(\mathrm{O}_{3}\right)$ result basically from photochemical reactions among precursors and, as such, are controlled by air mass characteristics such as temperature, humidity, and cloud cover/solar radiation. Accordingly, changes in trace gases' concentrations are modified with respect to exposure of the differing air masses driven by changes in atmospheric circulation.

A second substantial shortcoming in trying to associate changes in pollutant concentration to variation in circulation patterns is their different life span and distribution. For example, durable greenhouse gases (GHGs) such as methane $\left(\mathrm{CH}_{4}\right)$ and carbon dioxide $\left(\mathrm{CO}_{2}\right)$ are characterized by long lifetimes of years as compared to nitrogen oxides and aerosols which are most relevant for short spatial and temporal scales (Andreae, 2001; Voulgarakis et al., 2010). Radiative forcing of aerosols is of much higher spatial variability than GHG forcings due to the relatively short aerosol lifetime (daily-weekly scale) compared to that of GHGs (monthlyyearly scale).

Both natural and man-made factors converge over the EM, favoring the accumulation of pollutant concentration during summer. This region is in the crossroad of both largescale convective motions: Hadley and Walker cells leading to subsidence. This process results in a reduced mixing depth, which inhibits an efficient dispersion of the pollutants. Moreover, the EM is a hotspot of high solar radiation driving the photochemistry of the atmosphere. In addition, the prevailing summer westerlies at shallow tropospheric layers favor the transport of pollutant-enriched air masses from central and eastern Europe to the eastern Mediterranean (EM). Based on the above key factors, this review focuses explicitly on sum- mertime. Lelieveld et al. (2002) studied air pollutant transport over the EM in summertime. They report that the synoptic flow is controlled by the strong east-west pressure difference between the Azores high and the Asian monsoon low, with additional influence in the upper troposphere from the Tibetan anticyclone. This yields a contrasted situation in the tropospheric column with European influence in the lowermost troposphere, a much longer-range transport from Asia and North America at mid-tropospheric levels, and a major impact from Asia in the upper troposphere and lower stratosphere.

Desert dust is abundant over the EM, transported from two major source regions: the north African Sahara and the Arabian deserts. However, in general and predominantly, mineral dust affects the EM during all seasons except summer (e.g., Dayan et al., 1991; Moulin et al., 1998; Sciare et al., 2003), which is the reason why mineral dust is not in the scope of this study which is focused on summer conditions.

In this review, we first describe the atmospheric dynamic conditions favoring the build-up of tropospheric air pollutant concentrations. Secondly, we propose a synthesis of the essential studies on air pollutant concentrations including $\mathrm{O}_{3}$, sulfate $\left(\mathrm{SO}_{4}\right)$ aerosols, total reactive nitrogen $\left(\mathrm{NO}_{y}\right)$, carbon monoxide (CO), and $\mathrm{CH}_{4}$. The sources of the data reported include in situ observations, balloon-sounding, aircraft, and space-borne observations as well as model data, the results of which, in terms of dynamics, are mostly updated over 19482016 based on availability.

\section{Summer atmospheric dynamic conditions favoring the build-up of tropospheric pollutants concentrations}

Different spatial and temporal scales of motion affect pollutant transport and dispersion: the microscale, mesoscale, synoptic scale, and macroscale, or global scale. At the scale of a few months, the planetary boundary layer is relatively well mixed. However, on shorter timescales and near the Earth's surface (where pollutants are emitted), transport and dispersion are often limited by atmospheric conditions. In this section, we will focus on the global- and synoptic-scale processes that favor a potential accumulation of pollutants in the EM troposphere.

\subsection{Global and synoptic scales inducing subsiding conditions over the eastern Mediterranean}

In general, the atmospheric conditions over the EM are persistent during the summer and subject to two essential processes. The first is the cool advection at shallow tropospheric layers caused by the strong, dry north Etesian winds generated by the east-west pressure gradient manifested by largescale circulation features, low pressures over the EM as an extension of the Persian Trough (PT), and the high pressure 


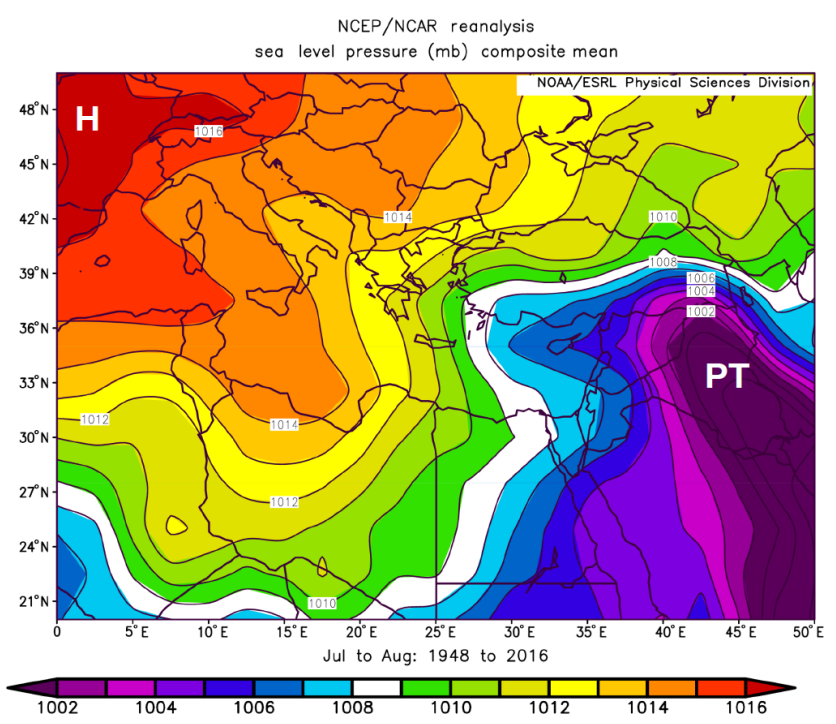

Figure 1. Composite long-term mean sea-level pressure $(\mathrm{hPa})$ for July-August over 1948-2016. "PT" indicates the Persian Trough position. "H" indicates the anticyclone position. NCEP reanalysis data are provided by the NOAA/OAR/ESRL PSD, Boulder, Colorado, USA; http://www.esrl.noaa.gov/psd/.

over central and southeastern Europe (Tyrlis and Lelieveld, 2013). This surface low-pressure trough extends from the Asian monsoon through the Persian Gulf and further along southern Turkey to the Aegean Sea (Figs. 1 and 2). The second is the dynamic subsidence generated by several globalscale processes: the African monsoon as part of the subtropical descending branch of the Hadley cell (Fig. 3a), the Asian monsoon as part of the Walker cell (Fig. 3b) and subsidence caused by the negative relative vorticity characterizing this region, during summer, as explained further on.

Rodwell and Hoskins (1996) used a hydrostatic primitive equation model initialized by a 6-year June to August climatology derived from European Center for Medium Range Weather Forecasts (ECMWF) analyses to investigate the monsoon desert mechanism enhancing summertime descent in the Mediterranean subtropics. They argued that the subsidence center in the EM is governed by the Asian monsoon rather than by the Hadley circulation and explained it by diabatic heating in the Asian monsoon region that induces a Rossby wave to its west, which generates air masses' descent. This adiabatic descent balances the horizontal advection on the southern flank of the midlatitude westerlies. Among the summertime descent regions, the strongest is located over the EM. Initiation of the descent over the EM coincides with the northward movement of heating during the onset of the monsoon. The anticyclonic center over northwest Africa and the monsoon result in an adiabatic warming that reduces the specific humidity and consequently enhances further the descent due to diabatic radiative cooling under cloudless sky conditions. Moreover, trajectory calcu-

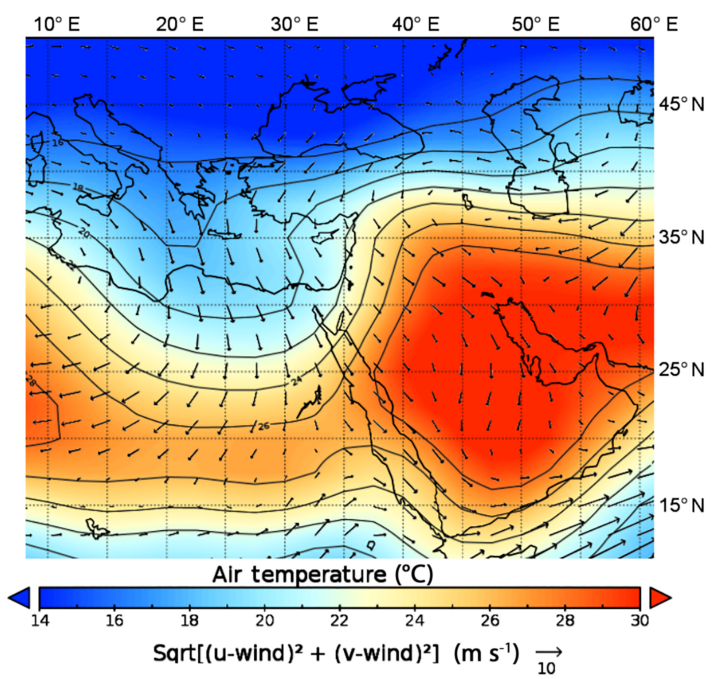

Figure 2. NCEP/NCAR reanalysis composite long-term mean temperature at $850 \mathrm{hPa}(\sim 1500 \mathrm{ma}$ a.s.l. $)$ with wind vectors, averaged over 1948-2016, for July-August. Note the southward penetration of the European cold air over the Mediterranean Basin. This cold air mass is transported at shallow tropospheric layers towards the eastern Mediterranean by the Etesian northwesterlies characterizing the Persian Trough. NCEP reanalysis data are provided by the NOAA/OAR/ESRL PSD, Boulder, Colorado, USA; http: //www.esrl.noaa.gov/psd/.

lations performed by Rodwell and Hoskins (1996) revealed that the bulk of the sinking air masses originate from midlatitude regions rather than over the intense monsoon convection areas over northern India. This is consistent with Tyrlis et al. (2013), who analyzed the thermodynamic state over the EM and calculated the temperature changes caused by horizontal advection by using ECMWF forecasts for diabatic heating over this region. They found that subsidence at middle and lower levels is primarily driven by the midlatitude westerly flow. Furthermore, Tyrlis et al. (2013) pointed at the steep slopes of the isentropes in the free troposphere caused by the westward migration of the mid- and upperlevel warming of the atmosphere away from the diabatic heating sources, which further enhance subsidence over the EM.

However, subsidence is neither restricted to midtropospheric levels nor solely associated with the descending branch of both of these general circulation cells. In summer, at higher atmospheric layers, air masses converge and subside over the EM as contributed by an anticyclonic curvature caused by anticyclonic centers formed over the Balkans. Such centers cannot be considered as extensions of the Azores high since they exhibit typical warm-core high structures from the surface up to mid-tropospheric levels (Anagnostopoulou et al., 2014). Tyrlis and Lelieveld (2013) point at wave disturbances originating over the North Atlantic that activate intense ridges over the Balkans. These ridges are further amplified by anticyclonic vorticity advec- 

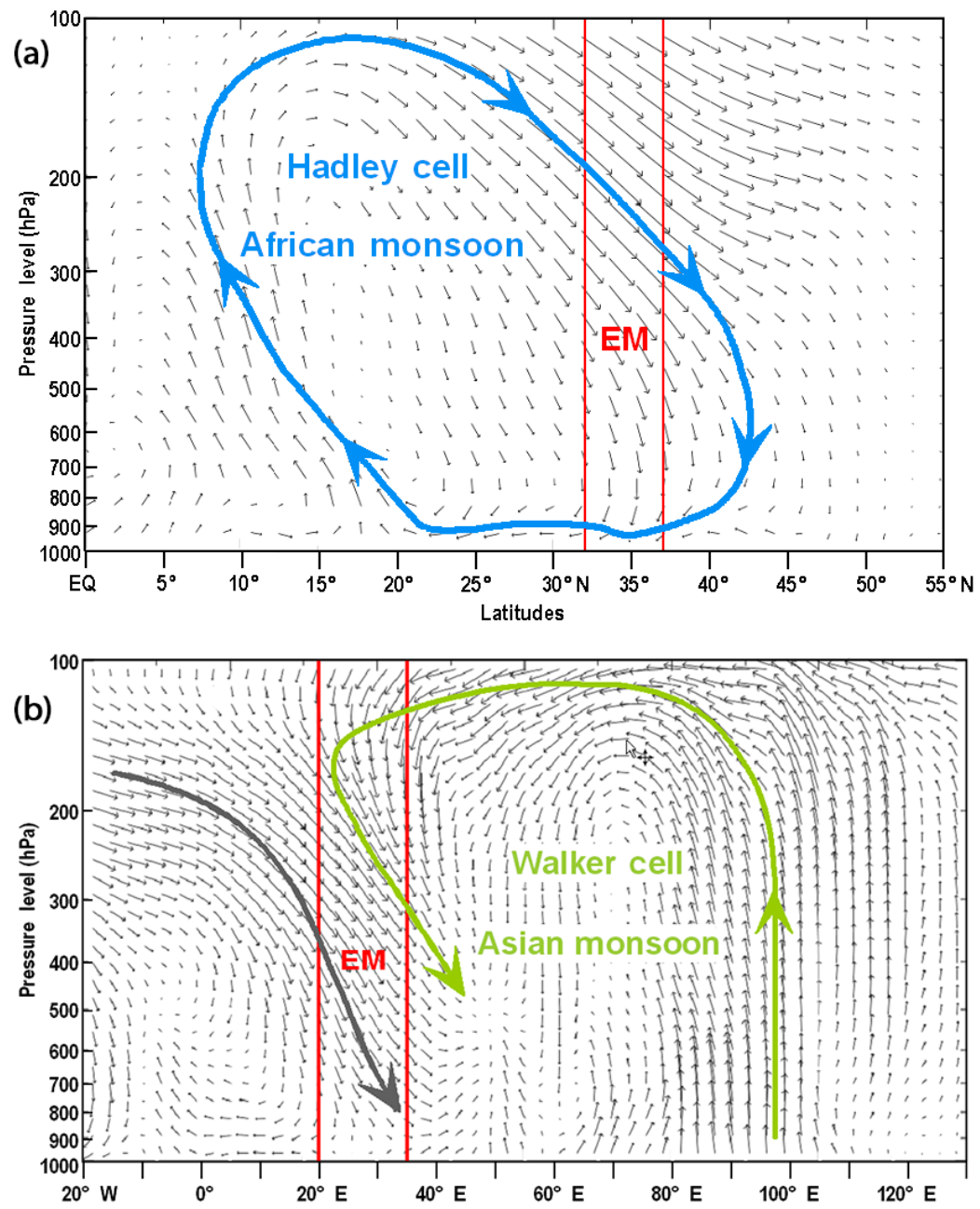

Figure 3. (a) Closed Hadley cell circulation of the African monsoon depicted by the vertical cross section of wind vectors for July-August, averaged over the $30-40^{\circ} \mathrm{E}$ longitudinal band. (b) Closed Walker cell circulation of the Asian monsoon depicted by the vertical cross section of wind vectors for July-August, averaged over the $20-35^{\circ} \mathrm{N}$ latitudinal band. The two figures are based on the NCEP/NCAR long-term averages (1948-2016) with the position of the eastern Mediterranean (EM) in red. NCEP reanalysis data are provided by the NOAA/OAR/ESRL PSD, Boulder, Colorado, USA; http://www.esrl.noaa.gov/psd/.

tion from northwestern Africa and, in tandem with diabatic cooling under clear skies, form such centers over central and southeastern Europe. The second dynamic factor inducing subsidence is an anticyclonic wind shear as related to the position of the subtropical jet. Under these circumstances, the southeastern part of the EM is exposed to the southern flank of the jet and therefore prone to negative shear vorticity. Although shear vorticity is an order of magnitude smaller than planetary vorticity, the nearby jet streak makes this relative vorticity component significant due to the strong change in wind speeds across the jet. Contribution of both components enhances negative vorticity, resulting in a total long-term mean negative vorticity of -1 to $-3 \times 10^{-5} \mathrm{~s}^{-1}$ at $200 \mathrm{hPa}(\sim 12 \mathrm{~km}$ a.s.l.) featuring the summer season over the EM (Fig. 4).
The contribution of the above-mentioned dynamic subsidence generated by all processes results in positive omega values, defined as the Lagrangian rate of change in pressure with time, indicating a downward air motion over the whole EM with its highest core of maximum subsidence over Crete, as depicted over mid-tropospheric levels $(500 \mathrm{hPa}$ geopotential height) (Fig. 5).

Following the subsidence caused by the large-scale downward motion, the warming and drying up are manifested by the delimiting sharp decrease in relative humidity over the EM basin (Fig. 6).

Based on National Centers for Environmental Prediction/National Center for Atmospheric Research (NCEP/NCAR) reanalysis for 2000-2012, Lensky and Dayan (2015) have recently shown that the coincidence of negative vorticity advection aloft accompanied by cold 


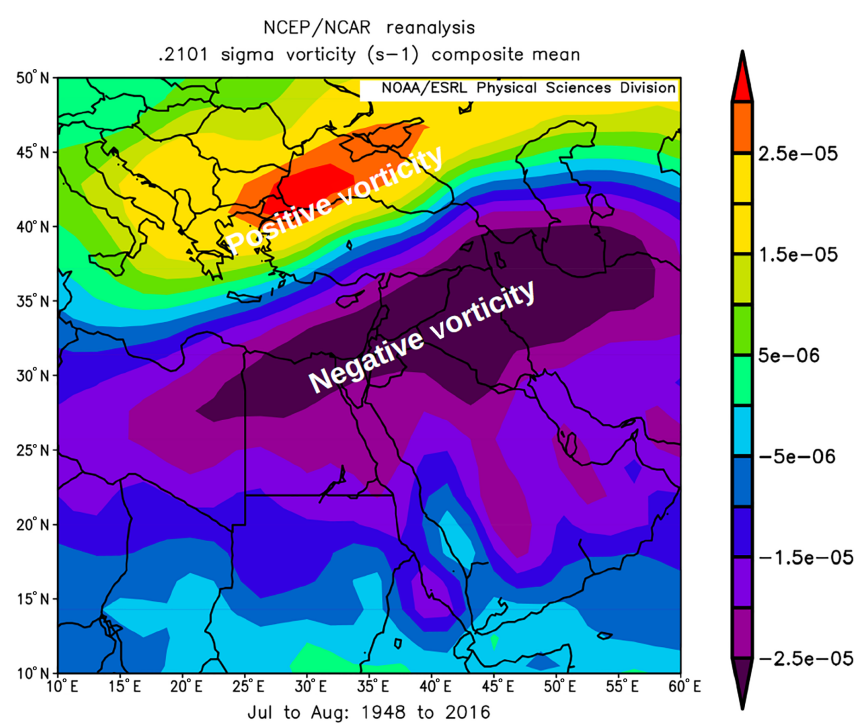

Figure 4. NCEP/NCAR reanalysis long-term averages (19482016) of the relative vorticity at $200 \mathrm{hPa}(\sim 12 \mathrm{kma}$.s.1.) for JulyAugust. The relative vorticity vector is generally perpendicular to the ground, positive when the vector points upward, and negative when it points downward. Note the negative relative vorticity region located over the southeastern Mediterranean as a result from both shear and curvature negative relative vorticity. Relative vorticity units are $10^{-5} \mathrm{~s}^{-1}$. NCEP reanalysis data are provided by the NOAA/OAR/ESRL PSD, Boulder, Colorado, USA; http://www.esrl.noaa.gov/psd/.

horizontal advection, at lower tropospheric levels, featuring the EM during PT synoptic conditions, drive the wind flow out of the thermal wind balance inducing a vertical downward motion (Figs. 2 and 7).

Ziv et al. (2004) found that the cool advection associated with the PT (Fig. 2) and the subsidence related to both descending branches of the African and Asian monsoons (Fig. 3) are interrelated and tend to balance each other. They suggest that this compensation mechanism explains the reduced day-to-day temperature variations over the EM in summer (Fig. 8).

However, this monotonic regime is interrupted by the occurrence of hot-day events resulting from an expansion of the subtropical high from north Africa towards the EM, which are prone to elevated concentration of air pollutants. Harpaz et al. (2014) found that such episodes are confined to the lower $4 \mathrm{~km}$ and controlled by the intensity of the negative temperature advection rather than by the prevailing subsidence.

\subsection{Atmospheric dispersion conditions over the eastern Mediterranean}

The vertical velocity involved in the mixing process within the turbulent layer near the surface and specifically its depth are important parameters in determining air pollutant con-

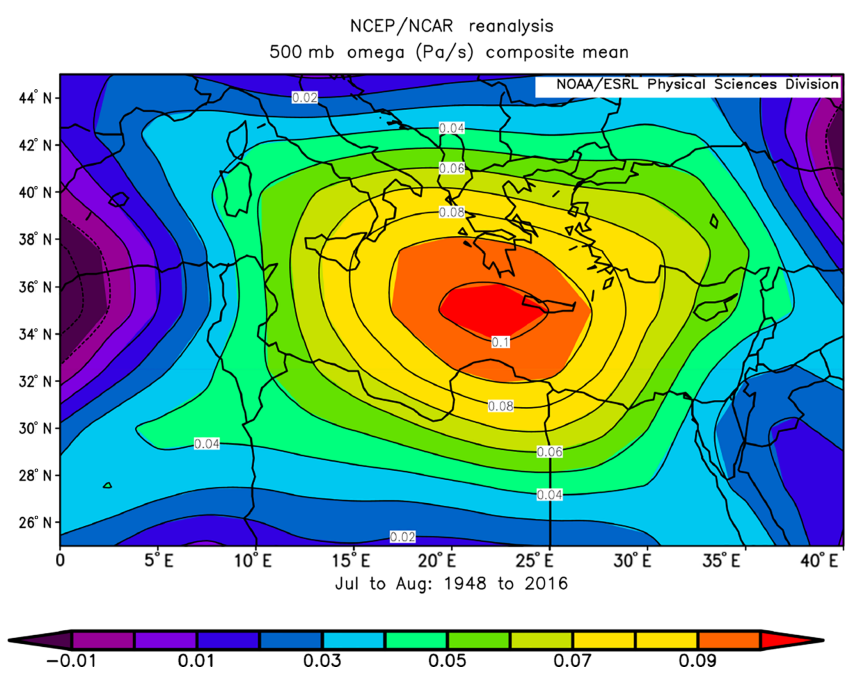

Figure 5. NCEP/NCAR reanalysis long-term averages of omega $\left(\mathrm{Pa} \mathrm{s}^{-1}\right)$ at $500 \mathrm{hPa}(\sim 5.5 \mathrm{~km}$ a.s.l. $)$ designating vertical motion for July-August 1948-2016. The maximum subsidence of $0.1 \mathrm{Pas}^{-1}$ is equivalent to a downward air motion of $\sim 1.5 \mathrm{~cm} \mathrm{~s}^{-1}$. NCEP reanalysis data are provided by the NOAA/OAR/ESRL PSD, Boulder, Colorado, USA; http://www.esrl.noaa.gov/psd/.

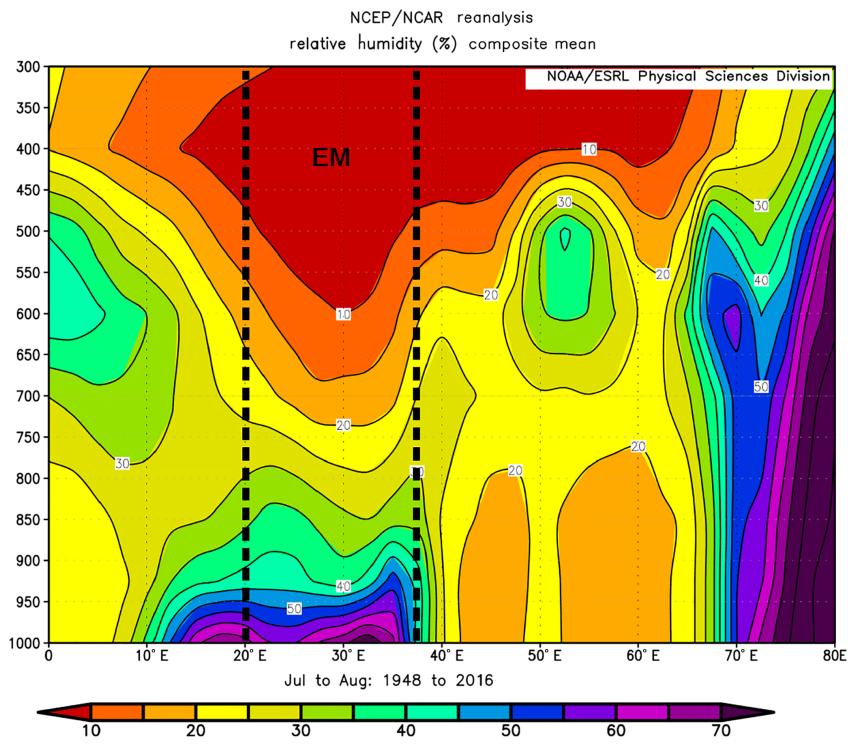

Figure 6. Long-term mean vertical cross section of relative humidity, averaged over the $31-36^{\circ} \mathrm{N}$ latitudinal band for JulyAugust 1948-2016 with the eastern Mediterranean position, in dashed black lines. NCEP reanalysis data are provided by the NOAA/OAR/ESRL PSD, Boulder, Colorado, USA; http://www. esrl.noaa.gov/psd/.

centrations at shallow tropospheric levels (Zhang and Rao, 1999). The changes in the mixing layer depth (MLD, i.e., the height of the convective atmospheric boundary layer marked by the base of a thermal inversion) is governed by several factors: surface heating (Holtslag and Van Ulden, 1983), 

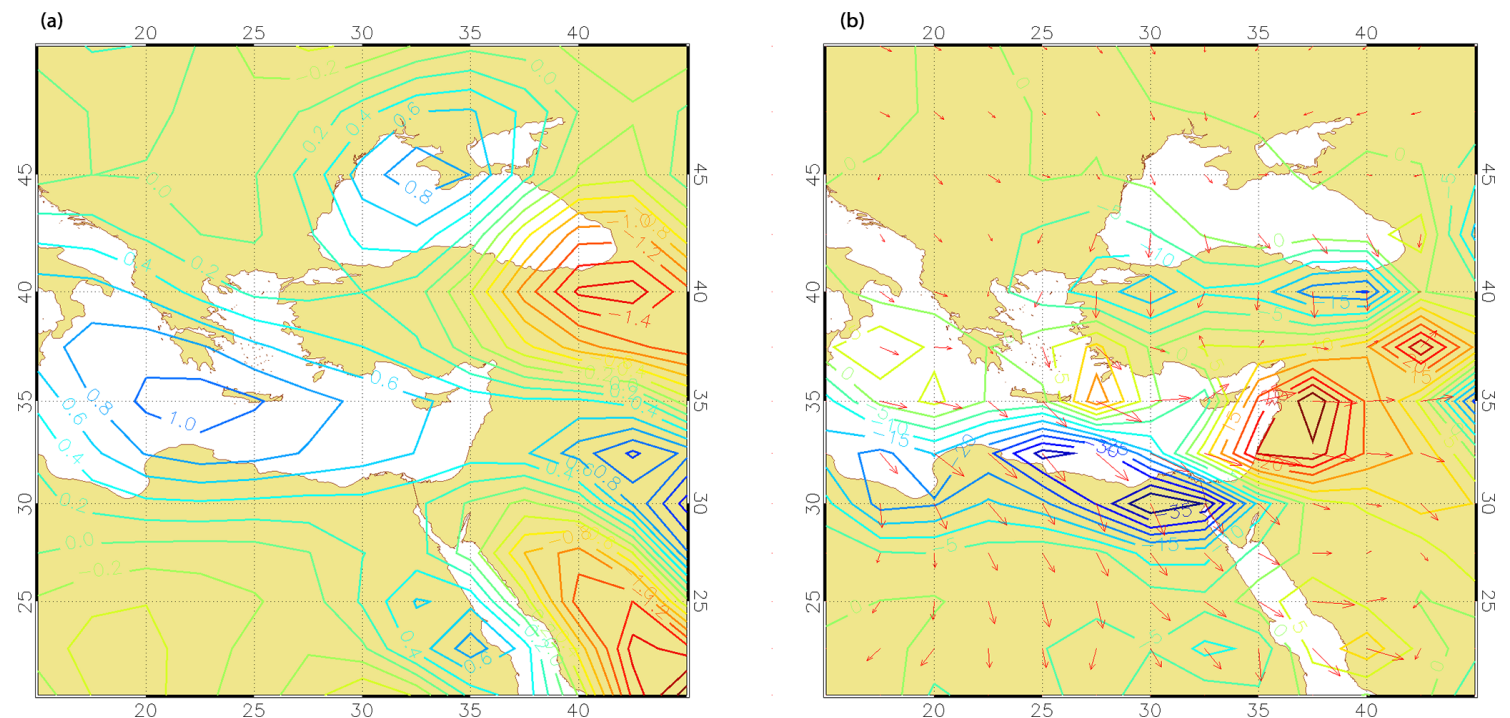

Figure 7. (a) Blue contours display positive omega values $\left(\mathrm{cm} \mathrm{s}^{-1}\right)$ representing the vertical descending air motion at a mid-tropospheric level $(700 \mathrm{hPa})\left(\sim 3 \mathrm{~km}\right.$ a.s.1.) pointing at a core of $1 \mathrm{~cm} \mathrm{~s}^{-1}$ located over Crete. Red contours are negative omega values. (b) Blue contours display cold advection calculated as multiplication of the horizontal thermal gradient by the wind vector. Red contours indicate warm advection, both at $995 \mathrm{hPa}$ level, equivalent to about $140 \mathrm{~m}$ a.s.l. at 12:00 UTC during Persian Trough summer synoptic conditions. NCEP reanalysis data for 2000-2012 are provided by the NOAA/OAR/ESRL PSD, Boulder, Colorado, USA; http://www.esrl.noaa.gov/psd/.

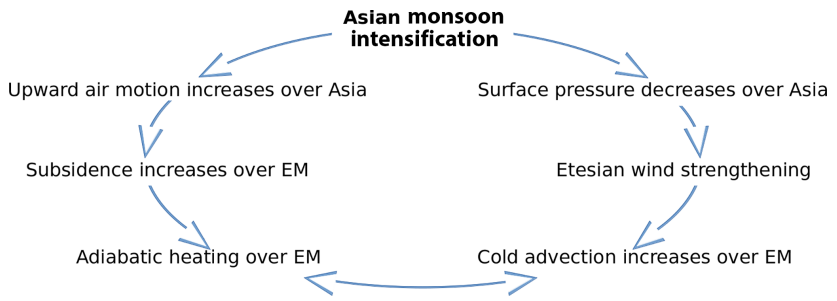

Figure 8. Schematic of the proposed mechanism during intensification of the Asian monsoon (reproduced from Ziv et al., 2004).

horizontal advection determined by the intensity of the sea breeze in coastal areas (McElroy and Smith, 1991; Lensky and Dayan, 2012), local terrain over the continent (Kalthoff et al., 1998), and the strength of the subsiding atmospheric air mass capping the mixed layer, defined by the temperature profile within this stable layer and synoptic-scale vertical motion (Dayan et al., 1988). Beside these factors, the MLD is controlled also by thermal advection associated with synoptic weather systems and therefore develops under strong forcing by synoptic-scale circulations (Businger and Charnock, 1983; Holt and Raman, 1990; Sinclair et al., 2010). Consequently, both the surface synoptic systems and their associated upper tropospheric conditions should be taken into consideration for understanding the behavior of the MLD over the EM basin and its adjacent coastal region.

Within the EM, numerous studies on the relationship between synoptic circulation and the structure of the MLD over the continental EM were conducted in Israel, the southeast-

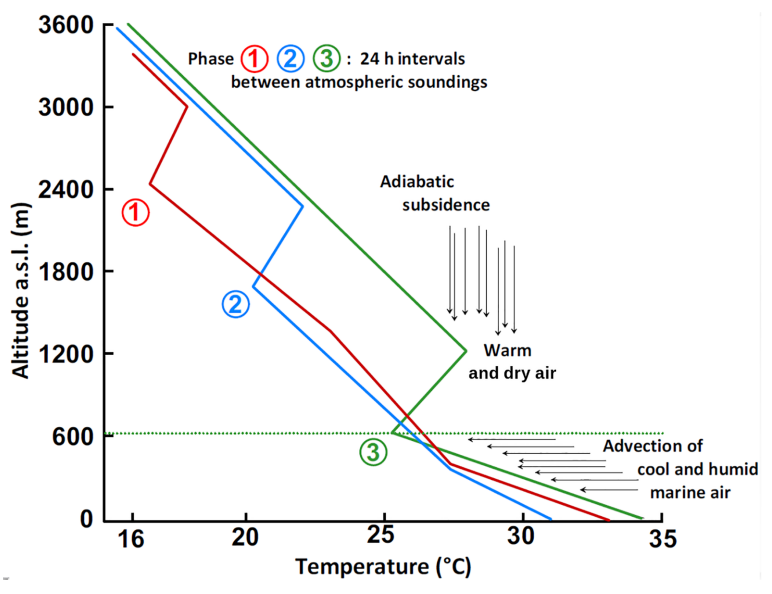

Figure 9. Successive schematic sounding thermal profiles indicating the downward motion of adiabatic subsidence accompanied by a weakening of the Persian Trough, which restricts the mixing layer depth to shallow layer of the atmosphere (phases $1-3$ are $24 \mathrm{~h}$ intervals between each sounding at Beit Dagan, Israel) (from Dayan et al., 1988; (CAmerican Meteorological Society; used with permission).

ern part of the basin. In particular, several studies were undertaken to characterize the spatial and temporal behavior of the MLD (Neumann, 1952; Halevy and Steinberger, 1974; Rindsberger, 1974, 1976; Dayan et al., 1988, 1996, 2002; Glaser et al., 1993; Lieman and Alpert, 1993; Dayan and Rodnizki, 1999; Ziv et al., 2004) using sounding measurements at the Israel Meteorological Service permanent site in 

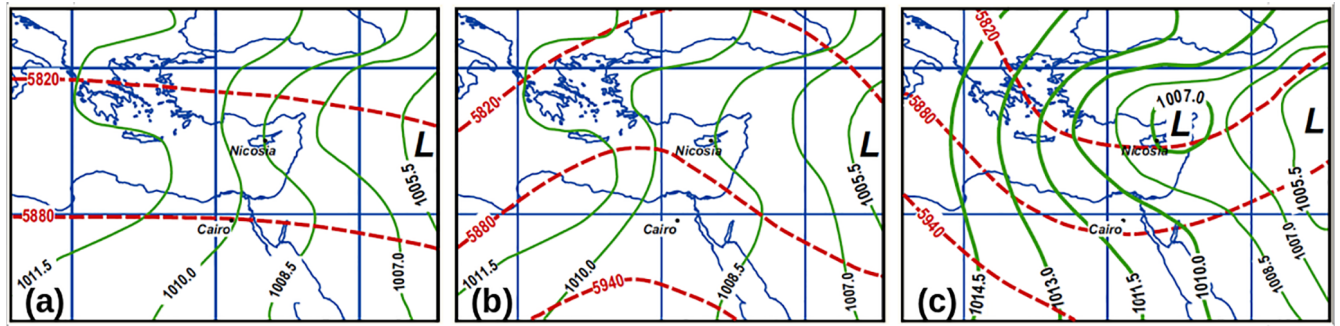

Figure 10. Typical synoptic charts showing the three modes: (a) moderate, (b) shallow, and (c) deep modes of the Persian Trough as defined by the surface-pressure differences between Nicosia (Cyprus) and Cairo (Egypt), and their associated upper-level conditions. Solid lines are isobars of sea-level pressure with $1.5 \mathrm{hPa}$ intervals. Dashed lines are contours at $500 \mathrm{hPa}$ level with $60 \mathrm{~m}$ intervals (from Dayan et al., 2002 ; (C)American Meteorological Society; used with permission).

Beit Dagan $\left(31.99^{\circ} \mathrm{N}, 34.82^{\circ} \mathrm{E} ; 39\right.$ ma.s.1.), $8 \mathrm{~km}$ southeast of Tel Aviv and at other sporadic sounding sites.

The atmospheric noon-time mixed layer during the summer over the EM region is indicated by a persistent elevated inversion base formed by a clear boundary line separating two differing air masses, a cool and humid mass above ground capped by much warmer and subsiding dry air. The MLD is controlled by the interlaced relationship between the downward motion of the subsiding air aloft and the depth of the PT at the surface (Fig. 9).

Due to the existing correlation between the MLD featuring the PT and air pollution episodes over the EM evidenced in previous studies (Dayan and Graber, 1981; Dayan et al., 1988; Koch and Dayan, 1992), this barometric system was classified into three essential types (Fig. 10) defined by the surface-pressure difference between Nicosia $\left(35.16^{\circ} \mathrm{N}\right.$, $33.36^{\circ} \mathrm{E} ; 149 \mathrm{~m}$ a.s.l.) in Cyprus and Cairo $\left(30.1^{\circ} \mathrm{N}, 31.4^{\circ} \mathrm{E}\right.$; $75 \mathrm{ma}$ a.s.1.) in Egypt, and the temperature at $850 \mathrm{hPa}$ in Beit Dagan (Israel): moderate PT, shallow PT, and deep PT (for details, see Dayan et al., 2002).

Analyses of upper-air measurements carried out regularly at Beit Dagan, in the central coastal plain of Israel, point at significant differences in the MLD for the several modes of the PT. The overall summer mean noon-time mixing depth values for 1981-1984 is $764 \pm 320 \mathrm{~m}$ (Dayan et al., 1988). A classification with respect to the modes defined above resulted in mean and SD values of $428 \pm 144 \mathrm{~m}$ and $1010 \pm 214 \mathrm{~m}$ for the shallow and deep PT modes, respectively (Koch and Dayan, 1992). The spatial distribution of the mixing depth is rather homogeneous under deep PT conditions over the central coastal plain of Israel as compared to the shallow mode where its value is kept almost uniform above sea level while penetrating inland. Due to the important implication of this behavior on the built-up concentration of air pollutants, the lateral variance of the mixing depth was tested for part of the upper-air measurements performed at four sites concurrently during the 1981-1984 campaign (Dayan et al., 1988). These sites on a west-east transect were Nizanim $\left(31.7^{\circ} \mathrm{N}, 34.63^{\circ} \mathrm{E} ; 10 \mathrm{~m}\right.$ a.s.l. $)$ on the southern coastal shore of Israel; Beit Dagan $\left(31.99^{\circ} \mathrm{N}, 34.82^{\circ} \mathrm{E}\right.$;
39 ma.s.l.) on the coastal plain; Ruhama $\left(31.5^{\circ} \mathrm{N}, 34.7^{\circ} \mathrm{E}\right.$; 210 ma.s.l.) $\sim 20 \mathrm{~km}$ inland in the northern Negev Desert; and Jerusalem $\left(31.77^{\circ} \mathrm{N}, 35.21^{\circ} \mathrm{E} ; 786 \mathrm{~m}\right.$ a.s.1.). The average thickness of the mixed layer when moving from the coast inland is reduced by $350 \mathrm{~m}$ while reaching Jerusalem (Fig. 11). The longitudinal variance of the MLD northsouth vertical cross section on 21 summer noon-time upperair measurements performed simultaneously at three sites $\sim 60 \mathrm{~km}$ apart along the Israeli coast revealed that the MLD decreases gradually from north to south (Dayan et al., 1988). This finding is explained by the greater distance of the southern sites from the cyclonic core of the PT (which persists in summer to the northeast of Israel) as well as the decreased distance from the anticyclonic center of the north African subtropical high (which persists during all seasons to the southwest of Israel). This lateral and longitudinal variance indicates that the most reduced summer MLDs are expected over the southeastern coast of the EM.

Most of the boundary-layer studies from other coastal regions in the EM were conducted over the Greek peninsula and the Aegean Sea. Kassomenos et al. (1995) analyzed the seasonal distribution of the MLD over the greater Athens area as obtained from the upper-air station of the Greek Meteorological Service at the Hellinikon airport for the period 1974-1990. They point at a noticeable annual variability in the afternoon MLD with maximum values $(\sim 800$ 1100 ma.s.l.) being observed by the end of July. They explain these high values observed during summer and the elevated inversion formed by the higher incoming solar radiation characterizing this season, which is efficiently converted into sensible heat flux, favoring the development of a deep mixing layer and the horizontal transport of warm air masses. Nevertheless, few summer days with stably stratified atmosphere and very low MLDs ( 300 ma.s.l. $)$ inducing high surface pollution levels in the Athens basin (Greece) were identified as well. This is consistent with Svensson (1996) who analyzed such a summer day over the Athens basin by applying a three-dimensional coupled mesoscale meteorological and photochemical model. Tombrou et al. (2015) mapped the MLD as part of the Aegean-GAME (Aegean Pol- 


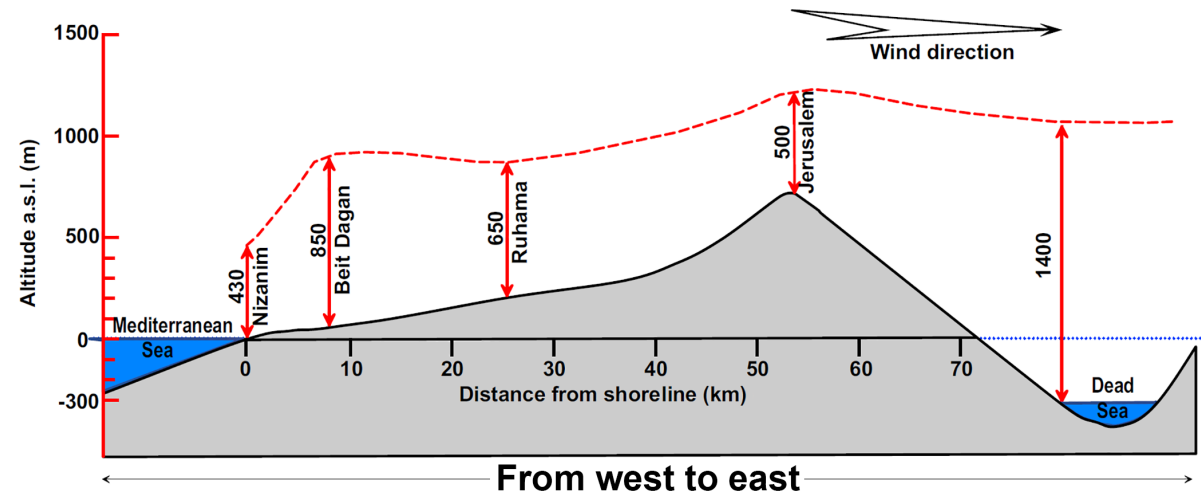

Figure 11. Schematic description of the lateral variation of the mixing layer depth (ma.s.l.) from the Mediterranean Sea to the Dead Sea (from Dayan et al., 1988; @American Meteorological Society; used with permission).

lution: Gaseous and Aerosol airborne Measurements) for two summer days under Etesian flow conditions over the Aegean Sea. The thermal profiles they analyzed demonstrate a wellinflated MLD of 700 to $1000 \mathrm{~m}$ a.s.l. during noon time over Crete as compared to the shallow marine boundary layer ( 400-500 ma.s.1.) observed over both the east and west Aegean marine regions.

Characterizing the structure of the MLD spatial variation offshore over the EM basin is important for getting better insight into the processes which control the dispersion of contaminants over the sea. A few investigators, including Gamo et al. (1982) and Kuwagata et al. (1990) for Japan, Stunder and Sethuraman (1985) for the United States, and Gryning (1985) for Denmark, have analyzed the spatial variations of the atmospheric mixing layer in coastal areas. Similar studies as related to the EM basin are quite limited and deal also mainly with the conditions not directly located over the open sea but rather at sites distant from the coastline.

In a 2006-2011 study based on a remote sensing tool, the ECMWF model, and radiosonde observations launched at Thessaloniki airport (Greece, $40.6^{\circ} \mathrm{N}, 22.9^{\circ} \mathrm{E} ; 10 \mathrm{~m}$ a.s.l.) $\sim 1 \mathrm{~km}$ from the coastline, Leventidu et al. (2013) found the MLD seasonal cycles peak with a summer maximum of 1400, 1800, and 2100 ma.s.l. in June, July, and August, respectively.

Much earlier in the unique study of this type that we are aware of, Dayan et al. (1996) evaluated the spatial and seasonal distribution of the MLD over the whole Mediterranean Basin. Based on $~ 65000$ air measurements from 45 radiosonde stations within and surrounding the basin from spring 1986 through winter 1988, the MLD was derived from the potential temperature gradient measured within the boundary layer and the capping stable layer above it. As expected, the summer values proved to be generally higher over land and minimum over the most eastern and western limits of the Mediterranean Basin (Fig. 12). They concluded that the distance from the coastline and topography are the main factors influencing the spatial distribution of the MLD. The

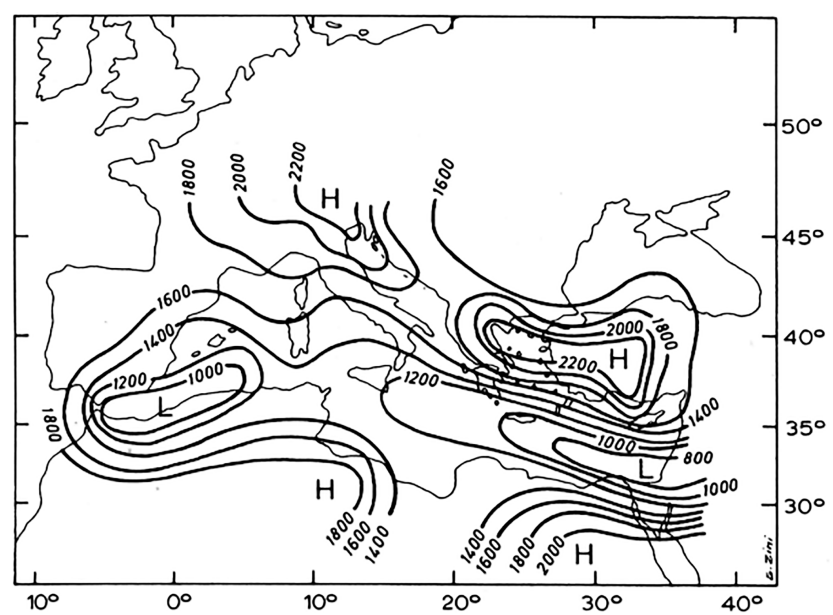

Figure 12. Seasonal map of the mixing layer depth (m) for the summer (June, July, August) of 1987 over the Mediterranean region at 12:00 UTC (from Dayan et al., 1996; used with permission from Kluwer Academic Publishers).

steep gradient in MLD values observed moving onshore is consistent with the elevated summer values in Thessaloniki (Greece) reported by Leventidu et al. (2013).

Dayan et al. (1996) found that the most striking temporal effect on MLD distribution over the basin is caused by synoptic weather systems and the intensity of the sea breeze along the coast. The diminishing of the MLD over the Mediterranean Basin moving from its center eastwards toward the EM coast that they have observed is consistent with the unique series of measurements of the temperature profiles performed during the summer of 1987 near the Port of Ashdod $\left(31.82^{\circ} \mathrm{N}, 34.65^{\circ} \mathrm{E}\right)$, some $40 \mathrm{~km}$ south of Tel Aviv (Israel) at 2 to $22 \mathrm{~km}$ from shore using a tethered balloon where prominent inversion bases of 350 to $600 \mathrm{~m}$ a.s.l. were observed (Barkan and Feliks, 1993). Moreover, such limited MLD values over the sea were obtained in the airborne Gradient in Longitude of Atmospheric constituents 
above the Mediterranean Basin (GLAM) campaign in August 2014 (Zbinden et al., 2016): the MLD over the sea measured in the period 6-10 August 2014 was approximately $800 \mathrm{~m}$ a.s.1. over Crete, diminishing to about 400-500 m a.s.1. over Cyprus.

The diurnal behavior of the MLD is assessed in the Israeli coastal plain based on routine radiosonde ascents that are, unfortunately, of coarse temporal resolution. The hourly maximum MLD is between 23:00 and 05:00 UTC for all seasons and decreases gradually toward its minimal value at 18:00 UTC (Dayan and Rodnizki, 1999).

However, since this cycle is governed mainly by synoptic weather systems, and the strength of the sea breeze, this behavior would be more significant for the summer. During this season, the variation of the mixed-layer height due to diurnal variations of solar radiation and local terrain effects is not obstructed by large-scale variations caused by frequent transitions between different synoptic configurations, as indicated by other seasons. Consequently, MLD variation is most evident during the summer, mainly controlled by the daily sea breeze cycle and heat fluxes that are most intensive at this time. The layer minimal depth of $760 \mathrm{~m}$ a.s.1. along the coast is usually observed during late afternoon hours when heat fluxes dissipate rapidly and the wind speed of the cool sea breeze reaches its minimal rate. This process results in a decrease of the marine turbulent boundary-layer depth (Dayan and Rodnizki, 1999). These MLDs are less developed as compared to the mean MLDs of 850 ma.s.l. observed over the Athens basin by Kassomenos et al. (1995).

Assessing the atmospheric dispersion conditions is commonly derived from the ventilation rates' calculation. This term is the MLD multiplied by the mean wind speed in the mixed layer, representing the potential of the atmosphere to dilute and transport contaminants away from a source region. Matvev et al. (2002) have calculated over 1948-1999 the mean and SD of the mixing depth, wind speed, and longterm range of ventilation rates at the Israel Meteorological Service sounding site in Beit Dagan (Israel) for the summer. A criterion usually adopted is that if the ventilation coefficient is less than $6000 \mathrm{~m}^{2} \mathrm{~s}^{-1}$, the site has limited ventilation (Dobbins, 1979; Pielke and Stocker, 1991).

Their results (Table 1) clearly show that the monthly longterm mean ventilation rates of $\sim 4500 \mathrm{~m}^{2} \mathrm{~s}^{-1}$ characterizing the EM coastal zone during summer are reduced and therefore inhibit an efficient dispersion of pollutants as compared to the summer mean values of $\sim 7000 \mathrm{~m}^{2} \mathrm{~s}^{-1}$ obtained by Kassomenos et al. (1995) over the greater Athens area.

\subsection{Air mass origins over the eastern Mediterranean}

The chemical composition of an air mass is inevitably related to its origin and pathway. Consequently, both of these terms are indispensable in explaining its composition (Fleming et al., 2012). Studies of the long-range transport (LRT) of pollution by trajectory models help us to interpret and better
Table 1. Monthly long-term means (LTMs) and Sds of the mixing layer depth (MLD), wind speed, and range of ventilation rates over Beit Dagan in the central coast of the EM. LTM and SD values for MLD include the years 1955-1968 (Rindsberger, 1974), 1981-1984 (Dayan et al., 1988), and 1987-1989 (Dayan and Rodniski, 1999). LTM and SD values for wind speeds are from the NCEP/NCAR reanalysis project (NOAA-CIRES Climate Diagnostics Center) for a 51-year data record over 1948-1999 from http://www.esrl.noaa. gov/psd/ (adapted from Matvev et al., 2002).

\begin{tabular}{lcc|rr|r}
\hline Month & \multicolumn{2}{c|}{$\begin{array}{c}\text { MLD } \\
(\mathrm{m})\end{array}$} & $\begin{array}{c}\text { Wind speed } \\
\left(\mathrm{m} \mathrm{s}^{-1}\right)\end{array}$ & $\begin{array}{r}\text { Ventilation } \\
\text { rates }\left(\mathrm{m}^{2} \mathrm{~s}^{-1}\right)\end{array}$ \\
\cline { 2 - 5 } & LTM & SD & LTM & SD & Range of LTM \\
\hline June & 810 & 470 & 5.5 & 2.25 & $1105-9920$ \\
July & 870 & 450 & 5.0 & 1.65 & $1365-8780$ \\
August & 820 & 395 & 4.5 & 1.50 & $1275-7290$ \\
\hline
\end{tabular}

define the movement and removal processes affecting atmospheric concentrations. Although changes in wind direction are observed on a diurnal and seasonal basis depending on the synoptic conditions affecting the region, the prevailing wind flows over the EM are from the west towards the east. Therefore, air pollutants emitted from upwind sources to the west of the EM will reach the EM and will be added to those emitted locally. Indeed, numerous observational and modeling studies have confirmed that the EM is affected by the long-range transport of air pollutants originating from Europe (e.g., Dayan, 1986; Luria et al., 1996; Wanger et al., 2000; Erel et al., 2002, 2007, 2013; Matvev et al., 2002; Rudich et al., 2008; Drori et al., 2012).

To get insight into the LRT over the EM, the Air Resources Laboratory's trajectory model (GAMBIT - Gridded Atmospheric Multi-Level Backward Isobaric Trajectories; Harris, 1982) was applied over 1978-1982 (Dayan, 1986). The duration of each trajectory was chosen as 5 days backward in time, enabling the tracing of air masses originating from Europe, the Mediterranean Basin, northern Africa, and the Near East close to the EM central coast of Israel (Fig. 13).

The $850 \mathrm{hPa}$ level ( $\sim 1500 \mathrm{~m}$ a.s.1.) was chosen as the most representative of the transport layer. This level is selected as the intermediary level between the surface wind regime and the regime of upper winds relatively free from local surface effects. Trajectory direction was divided into five distinctive geographical classes as shown in Fig. 13. Respective occurrences and seasonal distributions can be summarized as follows:

1. The long fetch of maritime air masses from northwest Europe crossing the Mediterranean Sea, accounting for $36 \%$, was the most frequent on average and fell evenly throughout the whole year.

2. Northeast continental flow that originated in eastern Europe, accounting for $30 \%$, was the most frequent during the summer season. 


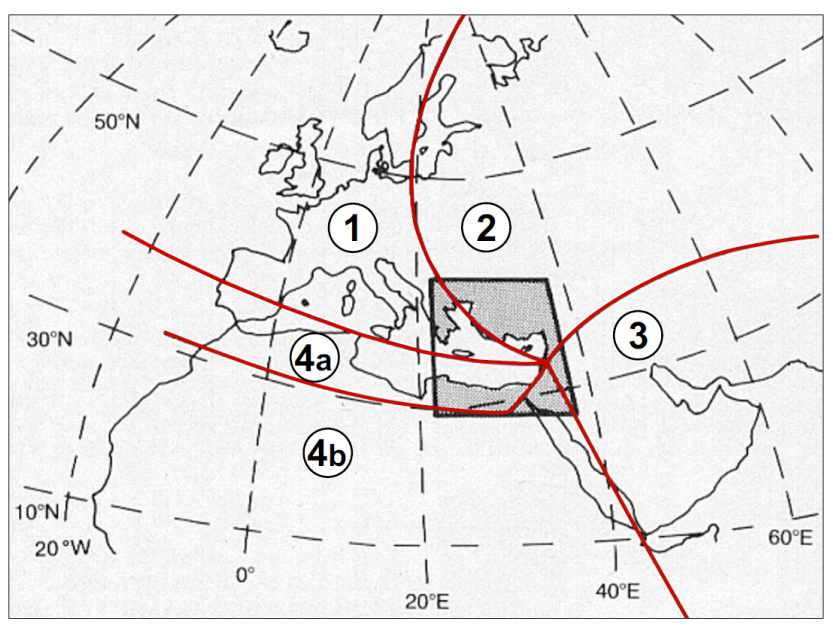

Figure 13. Trajectory typing method used to categorize 5-day back trajectories from the eastern Mediterranean region at $850 \mathrm{hPa}$ using the Air Resources Laboratory's trajectory model (GAMBIT) over the 1978-1982 period (from Dayan, 1986, CAmerican Meteorological Society; used with permission).

3. Southeast flow from the Arabian Peninsula, accounting for $5 \%$, was infrequent, occurring mainly during the autumn.

4a. Southwest flow along the north African coast, accounting for $11 \%$, was the most frequent during late winter and spring.

4b. South-southwest flow from inland north Africa accounted for $7 \%$, with a late winter and spring maximum.

Therefore, (1) and (2) trajectory types are indeed predominant with a summer maximum occurrence $(>66 \%$ ) over the EM coastal zone.

The 5-year (1983-1987) flow climatology study of back trajectories at Aliartos, Greece $\left(38.22^{\circ} \mathrm{N}, 23.00^{\circ} \mathrm{E}\right)$, revealed that about $40 \%$ of the $850 \mathrm{hPa}$ back trajectories arriving at this site during summer originate from northwest and north sectors (Katsoulis, 1999), which is consistent with the flow patterns reported by Kubilay (1996) for Mersin, Turkey. Katsoulis (1999) suggested that these predominant flow directions point at northeastern Europe and northwestern Asia as potential source regions.

These studies show that the main flow direction to the EM observed during summer lies between west and north wind sectors. This implies that the most probable source areas reaching and affecting the northern and eastern parts of this basin are the industrialized countries of eastern and central Europe located upwind of this part of the basin.

\section{Summer atmospheric air pollutant concentrations}

The EM is one of the regions in the world where elevated concentrations of primary and secondary gaseous air pollutants have been reported frequently. This region is influenced not only by local atmospheric dispersion conditions but also by the ability of the atmosphere to inherit a significant proportion of pollutants from European sources.

After reviewing the atmospheric dispersion and transport conditions characterizing the EM during the summer, a summary of the essential results published over the last decade dealing with trace gases and anthropogenic sulfate aerosol concentrations over this region is presented. These studies demonstrate how the above-described global- and synopticscale processes control the extent of transboundary transport of air pollutants and chemical composition and concentrations over the EM.

\subsection{Processes controlling $\mathrm{O}_{3}$ formation}

Most tropospheric $\mathrm{O}_{3}$ formation occurs when nitrogen oxides $\left(\mathrm{NO}_{x}\right), \mathrm{CO}$, and volatile organic compounds (VOCs) react in the atmosphere in the presence of sunlight. Due to cloud-free conditions, high incoming solar radiation characterizes the EM during summer (Lelieveld et al., 2002), which enhances the build-up of $\mathrm{O}_{3}$ concentrations.

Numerous researchers have identified the EM as a "hot spot" of summertime tropospheric ozone (e.g., Stohl et al., 2001; Roelofs et al., 2003; Zbinden et al., 2013; Zanis et al., 2014; Doche et al., 2014; Safieddine et al., 2014).

Zbinden et al. (2013) derived the climatological profiles and column contents of tropospheric $\mathrm{O}_{3}$ from the Measurement of Ozone by Airbus in-service Aircraft program (MOZAIC) over the mid-northern latitudes $\left(24\right.$ to $\left.50^{\circ} \mathrm{N}\right)$ over the 1994-2009 period. Among the 11 most visited sites by the MOZAIC aircrafts is the EM cluster, which comprises 702 profile data from the two airports in Cairo $\left(31.39^{\circ} \mathrm{E}\right.$, $30.10^{\circ} \mathrm{N}$, in Egypt) and Tel Aviv $\left(34.89^{\circ} \mathrm{E}, 32.00^{\circ} \mathrm{N}\right.$, in Israel), from which monthly means were derived. The $\mathrm{O}_{3}$ volume mixing ratio obtained were converted to Dobson units (DUs) and validated against coincident ozonesonde profiles. Considering all sites, the EM reaches the largest tropospheric $\mathrm{O}_{3}$ column concentration of $43.2 \mathrm{DU}$ in July, which is related to an extreme summer maximum within $1-5 \mathrm{~km}$, in agreement with the results derived from the space-borne Ozone Monitoring Instrument (OMI) and Microwave Limb Sounder (MLS) by Ziemke et al. (2011), pointing at the favorable photochemical conditions characterizing this region.

Zanis et al. (2014) identified a summertime pool with high $\mathrm{O}_{3}$ concentrations in the mid-troposphere over the EM over the 1998-2009 period as derived from the ERAInterim reanalysis $\mathrm{O}_{3}$ data, the Tropospheric Emission Spectrometer (TES) satellite $\mathrm{O}_{3}$ data, and simulations with the EMAC (ECHAM5-MESSy) atmospheric chemistry-climate model. They indicated that the high $\mathrm{O}_{3}$ pool over the mid- 


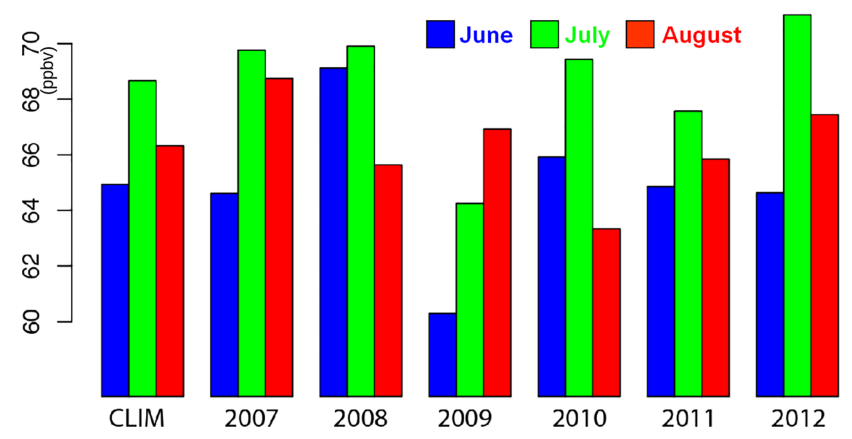

Figure 14. June, July, and August monthly means of $\mathrm{O}_{3}$ concentrations (ppbv) at $3 \mathrm{~km}$ partial column measured by IASI in summer (June, July, August) within the 2007-2012 period over the Mediterranean (IASI morning overpasses). Only the observations over the sea are considered in the averages. The monthly means referred to as "CLIM" represent the averages over the whole period (adapted from Doche et al., 2014).

troposphere is controlled by the downward transport from the upper troposphere and lower stratosphere over this part of the Mediterranean Basin (MB), which is characterized by large-scale subsidence. This subsidence is regulated by the Asian monsoon as described in Sect. 2.1. Furthermore, Zanis et al. (2014), based on previous case studies (e.g., Galani et al., 2003; Akritidis et al., 2010), climatological studies (e.g., Sprenger and Wernli, 2003; James et al., 2003), and their own results, deduced that the mechanism leading to high tropospheric $\mathrm{O}_{3}$ over the EM consists of two essential consecutive phases. In the first stage, an enrichment in stratospheric $\mathrm{O}_{3}$ occurs into the upper troposphere via a stratosphere-to-troposphere transport process. In the second stage, these $\mathrm{O}_{3}$-rich air masses are transported downward by the strong summertime subsidence characterizing this region.

Doche et al. (2014) analyzed tropospheric $\mathrm{O}_{3}$ concentrations for the 2007-2012 period as observed over the MB by the space-borne Infrared Atmospheric Sounding Interferometer (IASI). They identified an abrupt west-east $\mathrm{O}_{3}$ gradient in the lower troposphere over the Mediterranean Basin with the highest concentrations observed over its eastern part. These concentrations were observed at mid-tropospheric layers $(3 \mathrm{~km})$ caused by subsiding $\mathrm{O}_{3}$-rich air masses from the upper troposphere typifying summer. A clear and consistent seasonal variability emerges from their measurements, showing a maximum of the $3 \mathrm{~km}$ partial column $\mathrm{O}_{3}$ concentration in July (Fig. 14). This is consistent with the study of Tyrlis and Lelieveld (2013) who found that the key dynamic driving factors yielding to high $\mathrm{O}_{3}$ concentrations in late July and early August, in the middle and lower free troposphere, are maximum tropopause folding activities, i.e., stratospheric air intruding into the troposphere and the subsidence over the EM, featuring Etesian outbreaks, which are temporally well correlated with the Indian monsoon. This tropopause folding is manifested by a slightly lower tropopause in the middle and lower free troposphere observed during such outbreaks over the latitude of the Aegean, forming a narrow "transport corridor" of positive potential vorticity anomalies. Tyrlis and Lelieveld (2013) argue that such frequent subsidence of high potential vorticity illustrates the important role of stratospheric intrusions in the summer dynamic conditions over the EM. Furthermore, a climatology of tropopause folds over this region based on the ERA-Interim data spanning the period 1979-2012, identified the Anatolian plateau as a hot spot of fold development that occurs $\sim 25 \%$ of the time during July and August, and a seasonal evolution linked with the south Asian monsoon (Tyrlis et al., 2014). The contribution of tropopause folds in the summertime pool of tropospheric $\mathrm{O}_{3}$ over the EM was confirmed by Akritidis et al. (2016) as simulated with the EMAC atmospheric chemistry model.

Based on IASI measurements and the Weather Research and Forecasting Model with chemistry (WRF-Chem), Safieddine et al. (2014) have shown that the air column of the first $2 \mathrm{~km}$ above ground is enriched by anthropogenic $\mathrm{O}_{3}$. Above $4 \mathrm{~km}, \mathrm{O}_{3}$ is mostly originating from outside the Mediterranean Basin by LRT process or generated through stratosphere-to-troposphere exchange characterizing the EM during the summer.

Air masses from surrounding regions in the EM atmosphere have a great impact on surface $\mathrm{O}_{3}$ concentrations. In a recent study, Myriokefalitakis et al. (2016) have investigated the contribution of LRT to the $\mathrm{O}_{3}$ and $\mathrm{CO}$ budget in the EM basin using a global chemistry-transport model (CTM), the TM4-ECPL, driven by ECMWF interim reanalysis project (ERA-Interim) meteorology. They found that about $8 \%$ of surface $\mathrm{O}_{3}$ concentrations are affected by local anthropogenic emissions, whereas subsiding air masses from the free troposphere and horizontal transport from surrounding regions provide about 38 and $51 \%$ of $\mathrm{O}_{3}$ sources, respectively, into the EM mixed-layer depth. Although elevated $\mathrm{O}_{3}$ concentrations over the EM during the summer are mainly attributed to LRT of polluted air masses originating from Europe and lingering over the Mediterranean Basin, their enhancement as a secondary pollutant is also caused by their precursors emitted along the coasts of the EM. Consequently, several studies dealing with $\mathrm{O}_{3}$ concentrations measured over coastal sites surrounding the EM and its inland penetration are presented.

Measurements of $\mathrm{O}_{3}$ were performed at several sites in Crete and Greece and for rather long periods: over the northern coast of Crete in Finokalia $\left(35.50^{\circ} \mathrm{N}, 26.10^{\circ} \mathrm{E}\right)$, $70 \mathrm{~km}$ northeast of Heraklion, from September 1997 to September 1999 (Kouvarakis et al., 2000); from a rural area $\left(40.53^{\circ} \mathrm{N}, 23.83^{\circ} \mathrm{E}\right)$ close to Thessaloniki in the north of Greece from March 2000 to January 2001; and from an $\mathrm{O}_{3}$ analyzer installed in a vessel traveling routinely from Heraklion, Crete, to Thessaloniki, Greece, from August to November 2000. Based on these measurements, Kouvarakis et al. (2002) pointed out the existence of a well-defined sea- 
sonal cycle in boundary-layer $\mathrm{O}_{3}$, with a summer maximum both above the Aegean Sea and at Finokalia. They indicated that LRT is the main factor accounting for the elevated $\mathrm{O}_{3}$ levels above the EM. This finding is consistent with the 1997-2004 surface $\mathrm{O}_{3}$ time series at Finokalia (Crete) of Gerasopoulos et al. (2005), who investigated the mechanisms that control $\mathrm{O}_{3}$ levels and its variability. They identified transport from the European continent as the main mechanism controlling the $\mathrm{O}_{3}$ levels in the EM, especially during summer when $\mathrm{O}_{3}$ reaches a July maximum of $58 \pm 10$ ppbv. Moreover, on a larger regional scale, Kourtidis et al. (2002) used ozonesonde ascents, lidar observations, ship cruises, and aircraft flights to show that south and southwestern synoptic flows associated with Saharan dust events result in lower $\mathrm{O}_{3}$ above the planetary boundary layer by $20-35 \mathrm{ppbv}$, as compared to northerly flows, which transport air from continental Europe. Based on 16 years of $\mathrm{O}_{3}$ concentrations measured at the EMEP Agia Marina Xyliatou rural background station in Cyprus and three other remote marine sites over the western, central, and eastern parts of the island, Kleanthous et al. (2014) have shown that local precursors contribute to only about $6 \%(\sim 3 \mathrm{ppbv})$ of the observed $\mathrm{O}_{3}$. However, elevated concentrations of this secondary pollutant occurring in summer are attributed to LRT of air masses mainly originating from northerly and westerly directions. The summer average annual maximum of $54.3 \pm 4.7 \mathrm{ppbv}$ was observed to be related to the transport of polluted air masses from the Middle East, and eastern and central Europe toward Cyprus.

Despite the prevailing synoptic meteorological conditions featuring the EM in summer, the differing pathways of the LRT of polluted air masses can affect differently the buildup of pollutants concentrations. To investigate such changes, Wanger et al. (2000) performed a comprehensive study that included $150 \mathrm{~h}$ of instrumented aircraft monitoring flights comparing two events of air mass transport (September 1993 and June 1994) representing two distinct types of LRT. This airborne study comprised flight paths performed approximately $70 \mathrm{~km}$ offshore parallel to the Israeli coastline and $180 \mathrm{~km}$ in length with Tel Aviv in the center.

These flights were performed during midday under westerly wind flow conditions at an altitude of $300 \mathrm{~m}$ a.s.l. (well within the atmospheric mixed layer). While both wind flow conditions were nearly similar through the measurement periods and along the $180 \mathrm{~km}$ flight path, the air mass sampled in September 1993 was much "cleaner" than the one sampled in June 1994. The averaged $\mathrm{O}_{3}$ concentration of the first campaign was $39 \pm 7 \mathrm{ppbv}$ compared to $48 \pm 9 \mathrm{ppbv}$ in the second period. Wanger et al. (2000) model simulations showed that the pollution sources in southern Europe and the Balkans did not affect the EM coasts in September 1993, contrarily to the synoptic conditions and simulation results for the June 1994 period where the winds over the EM tended to be northwesterly and thus forced the polluted air masses toward the coasts of the EM.
The summer synoptic and dynamic conditions prevailing over the EM supply the essential ingredients for the buildup of $\mathrm{O}_{3}$ concentrations. Based on the similar climatic conditions between the Los Angeles Basin (USA) and the EM, Dayan and Koch (1996) proposed a theoretical description of the cyclic mechanism in summer, leading to fumigation (i.e., a downward dispersion of an enriched $\mathrm{O}_{3}$ cloud toward the ground) further inland from the EM coast. Under the deep mode of the PT, stronger westerly winds, acting as a weak cold front (Fig. 15, panel A1), penetrate far inland, undercutting the mixed layer polluted by $\mathrm{O}_{3}$ from the previous day (Fig. 15, panel A2). In this way, part of the mixed layer containing $\mathrm{O}_{3}$ is pushed upward and isolated from the ground. If the pressure gradient weakens on the following day, the western flow weakens (Fig. 15, panel B1). The cooling effect of the cool and moist marine air is consequently reduced and the convective boundary layer inflates rapidly. When the top of the mixed layer reaches the elevated $\mathrm{O}_{3}$ cloud, the latter is penetrated by convective currents (Fig. 15, panel B2) and parts of the cloud are entrained toward the ground in this fumigating process.

Elevated $\mathrm{O}_{3}$ concentrations ( $>117 \mathrm{ppbv}$ ) were measured at inland rural sites of central Israel during the 1988-1991 early summer months (Peleg et al., 1994). Based on air mass back-trajectory analyses, these elevated $\mathrm{O}_{3}$ mixing ratios were found only in the event of air masses passing over the Tel Aviv metropolitan area. Furthermore, the very low ratio of $\mathrm{SO}_{2}$ to $\mathrm{NO}_{x}$ (sulfur dioxide, $\mathrm{SO}_{2}$ ) clearly indicates that $\mathrm{O}_{3}$ precursors such as $\mathrm{NO}_{x}, \mathrm{CO}$, and VOCs originate mainly from fossil-fuel combustion from mobile sources (Nirel and Dayan, 2001). These pollutants are subjected to chemical and photochemical transformations in the presence of solar radiation and atmospheric free radicals to form $\mathrm{O}_{3}$.

Over central Israel, the main source for these precursors emitted along the Israeli coastline is transportation (Peleg et al., 1994). Since $\mathrm{O}_{3}$ and other secondary pollutant formation takes several hours, significant transport and mixing occur simultaneously with the chemical reactions (Seinfeld, 1989; Kley, 1997). Thus, increasing urban and commercial activity along the highly populated Israeli coastal region, together with expanding transportation activity in the Gaza region, was found to strongly deteriorate inland air quality and, specifically, cause increasingly elevated inland $\mathrm{O}_{3}$ levels. Model results showed that traffic emissions during the morning rush hour from the Tel Aviv metropolitan area contribute about $60 \%$ to the observed $\mathrm{O}_{3}$ concentrations (Ranmar et al., 2002). Moreover, their study showed the summer season features a shallow mixed layer and weak zonal flow, leading to poor ventilation rates, which restrict $\mathrm{O}_{3}$ dispersion efficiency. These poor ventilation rates result in the slow transport of $\mathrm{O}_{3}$ precursors, enabling their photochemical transformation under intense solar radiation during their travel inland from the EM coast.

However, elevated $\mathrm{O}_{3}$ concentrations are not limited to the summer over the EM. Dayan and Levy (2002) found 103 

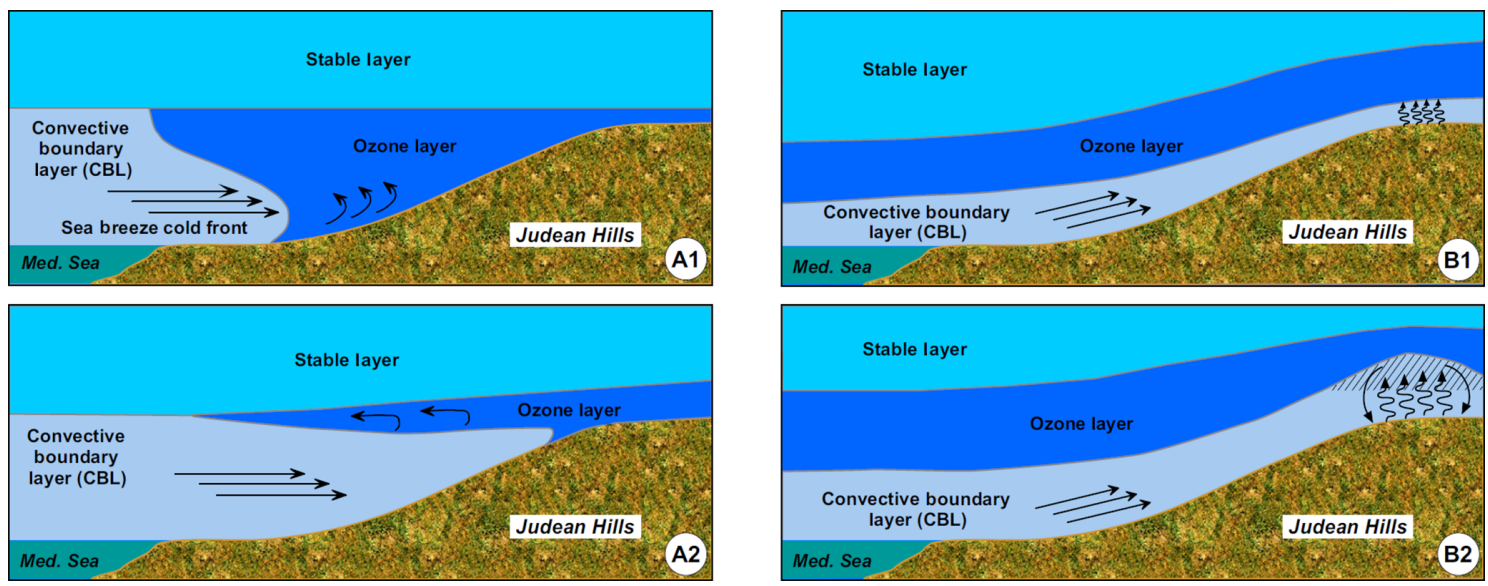

Figure 15. Scheme of the mechanism causing fumigation of a rich $\mathrm{O}_{3}$ cloud toward the ground as it moves inland over the eastern Mediterranean coast during the weakening of a deep mode of the Persian Trough (from Dayan and Koch, 1996; (CAmerican Meteorological Society; used with permission).

"high-ozone days" where $\mathrm{O}_{3}$ is $>80 \mathrm{ppbv}$ for at least $2 \mathrm{~h}$ based on 24 Israeli sites over 1997-1999. From their O $_{3}$ temporal analyses, they concluded that the highest values are more frequent during the transitional (spring and autumn) seasons (65\% of 103 days) than during the summer season $(35 \%)$.

Based on the recent remote sensing tools in conjunction with meteorological observations and models, we conclude on the three essential processes that control the $\mathrm{O}_{3}$ concentration during summer at various tropospheric levels over the EM: (1) in the shallow troposphere, the horizontal transport of $\mathrm{O}_{3}$-enriched air masses from eastern continental Europe to the region controlled by the anticyclonic center over central and southeastern Europe and the PT causing the Etesians; (2) the dynamic subsidence at mid-tropospheric levels; and (3) the stratosphere-to-troposphere exchange in the upper troposphere. At the surface of the EM coast, during transitional seasons, high $\mathrm{O}_{3}$ episodes are associated with hot and dry air masses originating east of Israel, where $\mathrm{O}_{3}$ precursor emissions are negligible, demonstrating that high $\mathrm{O}_{3}$ levels are more dependent on air mass characteristics than on upwind precursor emissions.

\subsection{Particulate sulfate $\left(\mathrm{SO}_{4}\right)$ abundance}

Globally, the two main particulate $\mathrm{SO}_{4}$ precursors are $\mathrm{SO}_{2}$ from anthropogenic sources and volcanoes, and dimethyl sulfide (DMS) from biogenic sources, especially marine plankton. In the EM atmosphere, particulate $\mathrm{SO}_{4}$ contributes more than $50 \%$ to the submicron aerosol mass (Bardouki et al., 2003a, b; Sciare et al., 2005). A first attempt to quantify the biogenic contribution caused by the oxidation of marine DMS as a possible source to particulate $\mathrm{SO}_{4}$ observed over the EM coastal region was carried out by Ganor et al. (2000). They used an instrumented aircraft during August 1995 to sample DMS and methane sulfonic acid (MSA) offshore and over land in Israel. Being exclusively produced by oxidation of DMS, MSA was used as tracer. Ganor et al. (2000) found this source as a rather limited contributor: between 6 and $22 \%$ of the non-sea-salt $\mathrm{SO}_{4}$ (nss-SO $\mathrm{SO}_{4}$ ) measured during summer was attributed to marine biogenic production. Evidently, several other factors favor particulate $\mathrm{SO}_{4}$ abundance over the EM. The homogeneous conversion of gaseous $\mathrm{SO}_{2}$ to particulate $\mathrm{SO}_{4}$ is rather slow, i.e., about 1$3 \% \mathrm{~h}^{-1}$ (Meagher et al., 1981). Wet deposition chiefly governs the atmospheric lifetime of $\mathrm{SO}_{4}$, estimated to be up to 6 days on a global average (Chin et al., 2000). Due to rainless conditions and associated wet deposition in summer, and the slow dry deposition velocity of $\mathrm{SO}_{4}$ aerosol $\left(\sim 0.01-0.4 \mathrm{~cm} \mathrm{~s}^{-1}\right), \mathrm{SO}_{4}$ aerosols account for $50-90 \%$ of the total sulfur $(\mathrm{S})$ in transported air masses toward the EM (Matvev et al., 2002). Two additional factors favor late spring and summer particulate $\mathrm{SO}_{4}$ regional abundance. First is the intense radiant energy emitted by the Sun under clearsky conditions that leads to an efficient oxidation of $\mathrm{SO}_{2}$ to $\mathrm{SO}_{4}$ via hydroxyl radical $(\mathrm{OH})$ as the predominant oxidant during daytime (Mihalopoulos et al., 2007). Second is the prevailing summertime westerly winds that transport $\mathrm{SO}_{4}$-rich air masses from sources over central Europe before significant removal occurs. A pioneering study to measure particulate $\mathrm{SO}_{4}$ in the background atmosphere of the EM was carried out by Mihalopoulos et al. (1997) in Finokalia, Greece. They reported a mean $\mathrm{SO}_{4}$ aerosol concentration of $188 \mathrm{neq}^{-3}\left(\sim 9 \mu \mathrm{g} \mathrm{m}^{-3}\right)$ with a minor marine contribution of about $5 \%$, resulting in a concentration of 178 neq m$^{-3}$ $\left(\sim 8.5 \mu \mathrm{g} \mathrm{m}^{-3}\right)$ for nss-SO $\mathrm{SO}_{4}$. These summer concentrations, about $10 \%$ higher than those observed in Thessaloniki (Tsidouridou and Samara, 1993), were associated with transport from eastern and central Europe. This is consistent with Sciare et al. (2003), who measured particulate nss- $\mathrm{SO}_{4}$ during a 1-month experiment in summer 2000 at a background 
site on Crete. They found a high average concentration of $6 \mu \mathrm{g} \mathrm{m}^{-3}\left(\sim 62 \mathrm{nmole}^{-3}\right)$ for air masses originating from Turkey and central Europe. Identical results were obtained by Koulouri (2008), who measured similar nss- $\mathrm{SO}_{4}$ concentrations during the period July 2004-July 2006.

Another source of $\mathrm{SO}_{4}$ aerosols is ship emissions, which contribute substantially to atmospheric pollution over the summertime Mediterranean region. Based on a regional atmospheric-chemistry model and a radiation model, Marmer and Langmann (2005) found that the summer mean $\mathrm{SO}_{4}$ aerosol column burden over the Mediterranean is $7.8 \mathrm{mg} \mathrm{m}^{-2}$, with $54 \%$ originating from ship emissions.

Concentrations of $\mathrm{SO}_{4}$-rich air masses have been measured intermittently at various downwind ground sites in Israel, the easternmost Mediterranean region, from an instrumented aircraft for a 10-year period between 1984 and 1993 by Luria et al. (1996). They found that the concentration of particulate $\mathrm{SO}_{4}$ observed during the summer was relatively high compared to other world locations, exceeding occasionally $500 \mathrm{nmole}^{-3}$ as compared to wintertime levels that were in the range of $50-100 \mathrm{nmole}^{-3}$. From airborne observations, Wanger et al. (2000) measured an averaged $\mathrm{SO}_{4}$ concentration of $38 \pm 7 \mathrm{nmole} \mathrm{m}^{-3}$ in their first series of measurement between 5 and 9 September 1993, and up to $108 \pm 63 \mathrm{nmole} \mathrm{m}^{-3}$ between 15 and 21 June 1994 . The annual average, calculated in Luria et al. (1996), is $100 \pm 15 \mathrm{nmole} \mathrm{m}^{-3}$, which is twice as high as predicted for the region by a global model and as high as reported for some of the most polluted regions in the USA. They pointed to several indicators suggesting that the origin of the particulate $\mathrm{SO}_{4}$ over the EM region is not from local sources but the result of LRT. The indicators include the lack of correlation between $\mathrm{SO}_{4}$ and primary pollutants, the high $\mathrm{SO}_{4}$ to total $\mathrm{S}$ values, the origin of the air mass back trajectories, and the fact that similar levels were observed during concurrent periods at different sites. Throughout their study, a higher concentration of $\mathrm{SO}_{4}$ was found during the afternoon hours, especially during the summer and at the inland locations. However, aerosol chemical analyses from a twostage aerosol sampler from a receptor site in Sde Boker $\left(31.13^{\circ} \mathrm{N}, 34.88^{\circ} \mathrm{E} ; 400 \mathrm{~m}\right.$ a.s.l.) in southern Israel, point at a significant decline of $24 \%$ of these elevated nss- $\mathrm{SO}_{4}$ mean concentrations for the summer months (July and August) from $\sim 3 \mu \mathrm{g} \mathrm{m}^{-3}$ in 1994 to $\sim 2.3 \mu \mathrm{g} \mathrm{m}^{-3}$ for 2004 . This decline is attributed to the decrease of $\mathrm{S}$ emissions in central and eastern Europe over the past 3 decades. Indeed, the majority $(60 \%)$ of the calculated air mass back trajectories related to extreme events (during which the fine fraction $\mathrm{S}$ concentration at Sde Boker exceeded a threshold of $3 \mu \mathrm{g} \mathrm{m}^{-3}$ ) originated from Russia, Ukraine, and the northern Black Sea region (Karnieli et al., 2009).

The effect of land and sea breeze on coastal meteorology in general and the interaction between land and sea breeze and air pollutants in particular plays an important role in determining many aspects of coastal environments around the world. A meteorological phenomenon that is often associated with the land and sea breeze is air mass recirculation in coastal regions (Miller et al., 2003; Levy et al., 2008). Sulfate particles measured along the central coast of Israel in midAugust 1987 and mid-August 1995, and identified by lesser microprobe analysis, have shown that the concentration during land breeze was $6-10$ times higher $\left(34.6-64.1 \mu \mathrm{g} \mathrm{m}^{-3}\right.$ ) as compared to sea breeze conditions $\left(4.3-7.1 \mu \mathrm{g} \mathrm{m}^{-3}\right)$ (Ganor et al., 1998).

In another attempt to quantify the S flux arriving at Israel's western coast from Europe and the Israeli pollution contribution to the air masses leaving its eastern borders towards Jordan, Matvev et al. (2002) conducted 14 research flights at an altitude of approximately 300 ma.g.l., measuring $\mathrm{SO}_{2}$ and particulate $\mathrm{SO}_{4}$ during the summer and autumn seasons. Two different legs were performed for each research flight: the first over the Mediterranean Sea, west of the Israeli coast, and the second along the Jordan Valley. Their results have shown that the influx of $\mathrm{S}$ reaching the Israeli coast from Europe varied in the range of $1-30 \mathrm{mg} \mathrm{Sh}^{-1}$, depending on the measuring season. The $\mathrm{SO}_{4}$ level in the incoming LRT air masses was at least $50 \%$ of the total S content. The contribution of the local pollutant sources to the outgoing easterly fluxes also strongly varied with the season. The Israeli sources contributed an average of $25 \mathrm{mg} \mathrm{Sh}^{-1}$ to the total pollution flux during the early and late summer as compared to only approximately $9 \mathrm{mg} \mathrm{Sh}^{-1}$ during the autumn period. The synoptic analysis indicates that conditions during the summer in Israel favor the accumulation of pollution species above the Mediterranean Basin from upwind European sources. This season is characterized by weak zonal flow within a shallow mixed layer that led to poor ventilation rates, limiting an efficient dispersion of these pollutants during their transport eastward. Under these summer conditions, influx local contribution and the total outflux of these pollutants are elevated as opposed to other seasons. To illustrate, during autumn, the EM is usually subjected to weak easterly winds, interrupted at times by strong westerly wind flows inducing higher ventilation rates. Such autumnal meteorological conditions and the lack of major emitting sources eastwards of Israel result in lower $\mathrm{S}$ budgets to and from Israel.

An estimate of the yearly flux showed that approximately $0.06 \mathrm{Tg} \mathrm{S}$ arrived at the Israeli coast from the west (Matvev et al., 2002). This is approximately $15 \%$ of the pollution leaving Europe towards the EM. The outgoing flux towards Jordan contributed by local sources was calculated to be $0.13 \mathrm{TgS} \mathrm{yr}^{-1}$, i.e., almost all the $\mathrm{S}$ air pollution emitted in Israel. The results of the flux rates for the $\mathrm{S}$ compounds over Israel are summarized in Table 2 for the different research flights and field campaigns. These latter results show for the early summertime that the uppermost fluxes from the west were averaging $0.19 \mathrm{Tg} \mathrm{yr}^{-1}$. During this season, the levels doubled the averages for late summer $\left(0.085 \mathrm{Tg} \mathrm{yr}^{-1}\right)$ and were over 5 times the average levels measured for the autumn $\left(0.035 \mathrm{Tg} \mathrm{yr}^{-1}\right)$. The wide range in fluxes derived is 
Table 2. Compilation by Rudich et al. (2008) of sulfate particulate concentrations and yearly fluxes from (a) Luria et al. (1996), (b) Wanger et al. (2000), and (c) Matvev et al. (2002).

\begin{tabular}{|c|c|c|c|c|}
\hline Regions & $\begin{array}{l}\text { Measurement } \\
\text { periods }\end{array}$ & $\begin{array}{l}\text { Conc. avg. } \\
\left(\text { nmole } \mathrm{m}^{-3}\right)\end{array}$ & $\begin{array}{l}\text { Yearly flux } \\
\left(\operatorname{Tgy}^{-1}\right)^{1}\end{array}$ & Authors \\
\hline \multirow[t]{5}{*}{ Judean Mountains } & Jul-Aug 1984, 1986 & 86 & 0.08 & \multirow[t]{8}{*}{ (a) } \\
\hline & May-Jun 1989 & 70 & 0.06 & \\
\hline & Jul-Aug 1987, 1988 & 103 & 0.09 & \\
\hline & Jul-Aug 1990 & 128 & 0.12 & \\
\hline & May, Jul 1990, 1991 & 85 & 0.08 & \\
\hline \multirow[t]{2}{*}{ Sea of Galilee } & Aug-Sep 1993 & 87 & 0.03 & \\
\hline & Dec 1993 & 71 & 0.07 & \\
\hline North coastal plain & Jun 1993 & 106 & 0.12 & \\
\hline \multirow{5}{*}{$\begin{array}{l}\text { Eastern } \\
\text { Mediterranean } \\
\text { coast }\end{array}$} & Sep 1993 & 38 & 0.08 & \multirow[t]{3}{*}{ (b) } \\
\hline & Jun $1994^{2}$ & 108 & 0.22 & \\
\hline & Jun 1998 & 105 & 0.16 & \\
\hline & Sep 1996 & 26 & 0.04 & \multirow[t]{2}{*}{ (c) } \\
\hline & Nov 1995 & 21 & 0.03 & \\
\hline
\end{tabular}

${ }^{1}$ Following Matvev et al. (2002), conversion from nmole $\mathrm{m}^{-3}$ to yearly fluxes takes into account the vector component of onshore wind speed, length of flight leg, and the MLD. ${ }^{2}$ The June 1994 flight has been performed during a highly polluted month over Israel.

explained by the varying distance from the polluted coastline.

The aerosol optical depth (AOD), the vertical integral over an atmospheric column of the incident light scattered and absorbed by aerosols, is often used to estimate the aerosol loading in the atmosphere. Particulate $\mathrm{SO}_{4}$ is among the numerous aerosol types. Nabat et al. (2013) compared AOD from several model data to satellite-derived data for the period 2003-2010 over the Mediterranean region. They found that the AOD seasonal cycle obtained from the Monitoring Atmospheric Composition and Climate (MACC) reanalysis model, which includes Moderate-Resolution Imaging Spectroradiometer (MODIS) AOD assimilation at $550 \mathrm{~nm}$, much resembles the satellite-derived AOD variability and has the best spatiotemporal correlation compared to AErosol RObotic NETwork (AERONET) stations. Based on these models and satellite-derived data, Nabat et al. (2013) have clearly shown that particulate $\mathrm{SO}_{4}$ has a maximum during spring and summer over the EM (Fig. 16). Matvev et al. (2002) performed airborne measurements along a $150 \mathrm{~km}$ line west of the Israeli coast. They derived an annual flux of the order of $0.06 \mathrm{Tg} \mathrm{yr}^{-1}$ of (dry) $\mathrm{S}$ across the corresponding surface. Given the observed ratio of $\mathrm{SO}_{4}$ to total $\mathrm{S}$ of $40-90 \%$ in the region (Matvev et al., 2002; Sciare et al., 2003), the annual flux of $\mathrm{SO}_{4}$ based on field measurements is 0.024 $0.054 \mathrm{Tg} \mathrm{yr}^{-1}$. Rudich et al. (2008) used satellite data to estimate the pollution transport toward the EM. MODIS Terraand Aqua-derived estimates of the annual $\mathrm{SO}_{4}$ flux along the same transect are 0.038 and $0.040 \mathrm{Tg} \mathrm{yr}^{-1}$, respectively, in the middle of the range obtained from field observations.

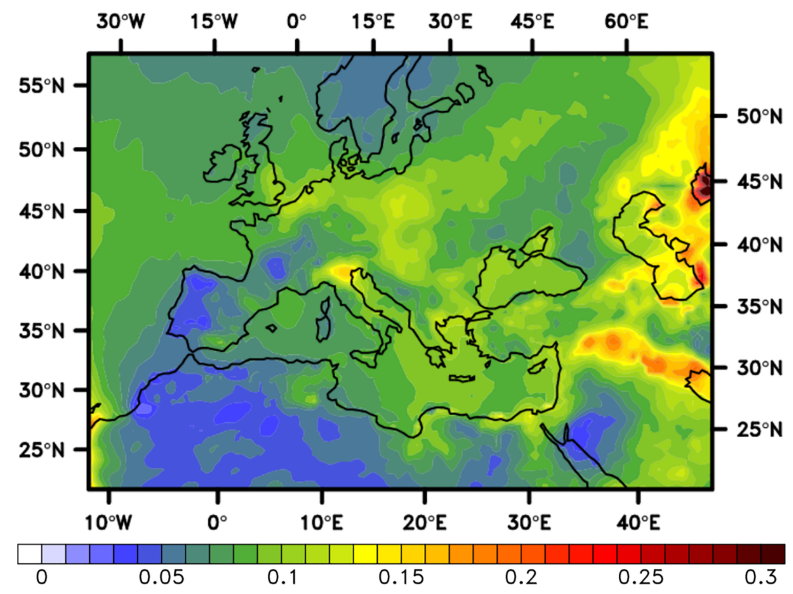

Figure 16. Average aerosol optical depth (AOD) contributed by particulate sulfate validated against AERONET AOD observations over the period 2003-2009. As mentioned at http://www.esrl.noaa. $\mathrm{gov} / \mathrm{gmd} / \mathrm{grad} / \mathrm{surfrad} / \mathrm{aod} /$, a value of 0.01 corresponds to an extremely clean atmosphere, and a value of 0.4 to a very hazy condition (the 2003-2010 average AOD over the Mediterranean Basin is $\sim 0.20$ ) (adapted from Nabat et al., 2013).

Rudich et al. (2008) also found that MODIS-based estimates (from Terra and Aqua satellites) of the $\mathrm{SO}_{4}$ flux agree reasonably well with the Goddard Chemistry Aerosol Radiation and Transport (GOCART) model simulations of anthropogenic $\mathrm{SO}_{4}$, as shown in Fig. 17 for seasonal averages. The annual $\mathrm{SO}_{4}$ flux from the GOCART model is $0.181 \mathrm{Tg} \mathrm{yr}^{-1}$, about $18 \%$ higher than the MODIS/Terra estimate of $0.153 \mathrm{Tg} \mathrm{yr}^{-1}$. Similar comparison on a sea- 


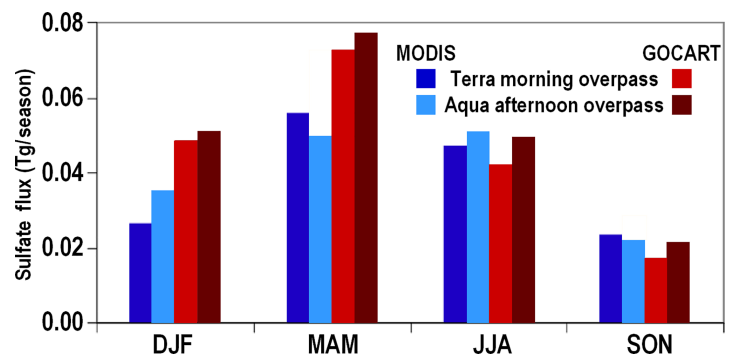

Figure 17. Seasonal flux $\left(\mathrm{Tg}_{\mathrm{geason}}{ }^{-1}\right)$ of dry sulfate as derived from MODIS/Terra and MODIS/Aqua space-borne observations compared to GOCART model-derived results, along the $150 \mathrm{~km}$ Israeli coastline of the eastern Mediterranean Sea. The seasons on the $x$ axis are winter (DJF), spring (MAM), summer (JJA), and autumn (SON) (adapted from Rudich et al., 2008).

sonal basis demonstrates that the GOCART model overestimates the winter (by $\sim 85 \%$ ) and spring (by $\sim 30 \%$ ) fluxes while it underestimates the summer and autumn fluxes by $10-25 \%$. If we consider the comparison between the GOCART model and MODIS/Aqua, the model annual flux is $0.201 \mathrm{Tg} \mathrm{yr}^{-1}$, about $25 \%$ higher than the MODIS/Aqua estimate of $0.159 \mathrm{Tg} \mathrm{yr}^{-1}$. On a seasonal basis, their estimates are in excellent agreement in summer and autumn but about $50 \%$ higher in the MODIS/Aqua winter and spring estimates. Based on the comparison of the two instruments, the model results, and the consistency with the aircraft measurements, they concluded that both MODIS instruments can be used for estimating the flux of pollution based on their daily AOD retrievals.

\subsection{Local formation and long-range transport of total reactive nitrogen $\left(\mathrm{NO}_{y}\right)$}

Total reactive nitrogen $\left(\mathrm{NO}_{y}\right)$ is a collective term for oxidized forms of nitrogen in the atmosphere such as nitric oxide (NO), nitrogen dioxide $\left(\mathrm{NO}_{2}\right)$, nitric acid $\left(\mathrm{HNO}_{3}\right)$, nitrous acid $\left(\mathrm{HNO}_{2}\right)$, nitrate $\left(\mathrm{NO}_{3}\right)$, nitrogen pentoxide $\left(2 \mathrm{~N}_{2} \mathrm{O}_{5}\right)$, peroxynitric acid $\left(\mathrm{HNO}_{4}\right)$, peroxyacetyl nitrate (PAN), and other organic nitrates (Emmons et al., 1997). Research studies measuring inorganic reactive nitrogen compounds over marine areas, in general, and more specifically over the EM basin, are scarce (Lawrence and Crutzen, 1999; Corbett et al., 1999; Veceras et al., 2008). Measurements of $\mathrm{NO}_{2}, \mathrm{HNO}_{3}$, and $\mathrm{HNO}_{2}$ undertaken with instrumentation aboard a research vessel in the Aegean Sea between 25 and 29 July 2000 revealed typical $\mathrm{NO}_{2}$ concentrations of 4 6 ppbv with a broad maximum of 20-30 ppbv. The level of $\mathrm{NO}_{2}$ was relatively high during the night and low during the day due to enhanced photochemical activity, vertical mixing, and the daily wind characteristics. Extreme $\mathrm{NO}_{2}$ concentrations were caused by upslope wind bringing air from marine traffic emissions trapped within the marine atmospheric boundary layer. The concentration of both nitric and nitrous acids in ambient air of the Aegean Sea was low (below 50 pptv). Večeřa et al. (2008) explained these results by the lack of precursors for these acids (Cohen et al., 2000), the high solar irradiation leading to $\mathrm{HNO}_{3}$ dissociation, and the reaction of $\mathrm{HNO}_{3}$ with sodium chloride aerosol.

$\mathrm{NO}_{y}$, identified as a precursor in the $\mathrm{O}_{3}$ formation, was measured by Wanger et al. (2000) for two summer airborne campaigns over the EM at an altitude of about $300 \mathrm{~m}$ (well within the MLD) using a high-sensitivity NO-NO analyzer (TEII $42 \mathrm{~S}$, chemiluminescence method, $\pm 0.1 \mathrm{ppbv}$ sensitivity). In the first campaign of September 1993, characterized by cleaner air mass conditions, an average $\mathrm{NO}_{y}$ concentration of $1.0 \pm 0.6 \mathrm{ppbv}$ was measured as compared to $3.9 \pm 1.8 \mathrm{ppbv}$ sampled during the June 1994 campaign.

The Mediterranean Intensive Oxidant Study (MINOS) campaign, performed in the summer of 2001, allowed Lelieveld et al. (2002) to examine the air pollution conditions at shallow and mid-tropospheric levels over the EM basin. During this experiment, elevated concentrations, typically 0.1 to $0.2 \mathrm{ppbv}$, of NO in the upper troposphere and only about 20 pptv within the MLD were observed at the Finokalia station. However, the value measured within the MLD at Finokalia was rather low and not typical for this site. From autumn 1998 to summer 2000, a Thermo Environmental Model $42 \mathrm{C}$ high-sensitivity chemiluminescence $\mathrm{NO}_{x}$ analyzer with a detection limit of 50 pptv was operated at Finokalia in parallel with the $\mathrm{O}_{3}$ analyzer to monitor $\mathrm{NO}$ and $\mathrm{NO}_{x}$ (Kouvarakis et al., 2002). During the whole examined period, NO concentrations ranged between $50 \mathrm{pptv}$ (most of the time) and $100 \mathrm{pptv}$, and $\mathrm{NO}_{x}{ }^{\prime}\left(\mathrm{NO}_{x}{ }^{\prime}=\mathrm{NO}+\mathrm{NO}_{2}+\mathrm{PAN}\right)$ between 0.1 and 4 ppbv. Kouvarakis et al. (2002) interpreted the very low $\mathrm{NO} / \mathrm{NO}_{x}{ }^{\prime}$ ratio obtained, which might indicate that the Finokalia station is affected by aged air masses. Furthermore, they argued that the similar diurnal amplitude of $\mathrm{O}_{3}$ above the Aegean Sea and at Finokalia during summer indicates that the regime of $\mathrm{NO}_{x}$ above the Aegean is similar to that observed at Finokalia.

The observed diurnal evolution at Finokalia of NO and $\mathrm{NO}_{z}{ }^{\prime}$ - the latter expressing mainly the sum of $\mathrm{NO}_{2}, \mathrm{NO}$, PAN-like compounds, organic nitrates, and $\mathrm{HNO}_{3}$ - was used as a tracer of pollution by Gerasopoulos et al. (2006) to analyze the diurnal variability of $\mathrm{O}_{3}$ over the EM. The diurnal cycles of these two tracers based on 3.5 years of measurements point at a maximum value of $\sim 70 \mathrm{pptv}$ for $\mathrm{NO}$ and up to $\sim 1.55 \mathrm{ppbv}$ for $\mathrm{NO}_{z}{ }^{\prime}$. These maxima were observed $1-2 \mathrm{~h}$ after the minimal $\mathrm{O}_{3}$ concentration was measured at about 06:30 UTC.

Ambient concentrations of $\mathrm{NO}, \mathrm{NO}_{2}$, and $\mathrm{NO}_{x}$ have been also reported over the northwestern parts of Turkey. An $\mathrm{NO}_{2}$ concentration of $8.5 \pm 4.8 \mathrm{ppbv}$ was obtained for the summer of 2005 by collecting weekly average data in a sampling site in the city Eskişehir, located $230 \mathrm{~km}$ to the west to the capital of Turkey, by use of passive samplers (Özden et al., 2008). Im et al. (2008) studied $\mathrm{O}_{3}$ pollution and its relationship with $\mathrm{NO}_{x}$ species based on hourly concentration 
levels of $\mathrm{O}_{3}, \mathrm{NO}$, and hydrocarbon measured between 2001 and 2005 in Kadıköy, an urban district in the Anatolian side of Istanbul. The mean and SD for the summer (June-August) $\mathrm{NO}, \mathrm{NO}_{2}$, and $\mathrm{NO}_{x}$ concentrations reported for this 5-year period were $14.4 \pm 6.2,22.7 \pm 2.7$, and $37.7 \pm 14.3 \mathrm{ppbv}$, respectively. Moreover, they suggested that the very strong correlation they found between $\mathrm{NO}$ and $\mathrm{NO}_{x}$ implies that the $\mathrm{NO}_{x}$ species are mainly from local sources.

Traub et al. (2003) analyzed several trace gas concentrations measured along flight tracks of the Deutsches Zentrum für Luft- und Raumfahrt (DLR) Falcon aircraft over the eastern and central Mediterranean Sea during MINOS in August 2001. In order to inquire into the role of LRT of pollutants in the air masses above the Mediterranean area and to determine their source regions, 5-day backward trajectories were computed and initialized along the Falcon flight tracks. They found that all trajectories with source regions in eastern Europe were associated with higher mean concentrations than those from westerly directions. Traub et al. (2003) measured mean $\mathrm{NO}$ and $\mathrm{NO}_{y}$ concentrations of $0.05 \pm 0.02$ and $1.4 \pm 0.4 \mathrm{ppbv}$, respectively, for the computed trajectories within the MLD originating from eastern Europe as compared to $0.04 \pm 0.01$ and $1.1 \pm 0.5 \mathrm{ppbv}$, respectively, for trajectories originating from western Europe.

Increasing urban and commercial activity along the highly populated Israeli coastal region, together with expanding transportation activity, has yielded few ground-based measurement studies in order to quantify the impact of local urban versus regional and foreign sources on the concentrations of the $\mathrm{NO}_{x}$ species, which vary in their atmospheric fate.

Results of half-hourly $\mathrm{NO}_{x}$ concentrations recorded from nine monitoring stations from 2002 to 2005 in the Haifa Bay, Israel, resulted in a typical mean mixing ratio of $25 \mathrm{ppbv}$ (Yuval et al., 2007) and a typical background value below $0.5 \mathrm{ppbv}$ for the summer over the EM (Alper-Siman Tov et al., 1997). This background value was further evidenced by Dayan et al. (2011) who analyzed $\mathrm{NO}_{x}$ concentrations during the Day of Atonement. On this day, all traffic and most of the industrial activities cease in the Jewish populated parts of the country, which provides a unique opportunity to test the relative contribution of pollution sources within urban centers versus regional and foreign sources.

In a study aimed at analyzing the sources and sinks of HONO in urban areas, and their seasonal dependency, Amaroso et al. (2008) carried out measurements of HONO, $\mathrm{NO}_{x}, \mathrm{O}_{3}$, and $\mathrm{SO}_{2}$ during autumn and summer in Ashdod $\left(31^{\circ} 49^{\prime} \mathrm{N}, 34^{\circ} 40^{\prime} \mathrm{E}, 10 \mathrm{~m}\right.$ a.s.l.) (south of Tel Aviv, Israel), a typical coastal Mediterranean urban area. The 15-day July campaign consisted of $43205 \mathrm{~min}$ averaged measurements, of $\mathrm{HONO}, \mathrm{NO}$, and $\mathrm{NO}_{2}$. $\mathrm{HONO}$ analyses were performed with a liquid coil scrubbing/UV-vis instrument (see Amaroso et al., 2008). $\mathrm{NO}$ and $\mathrm{NO}_{2}$ measurements were performed by a Thermo Model $42 \mathrm{C}$ NO-NO ${ }_{x}$ analyzer. The mean concentrations obtained for this campaign were $1.4 \pm 2.0,6.0 \pm 8.8$, and $14.8 \pm 7.3$ ppbv for $\mathrm{HONO}, \mathrm{NO}$, and $\mathrm{NO}_{2}$, respectively.

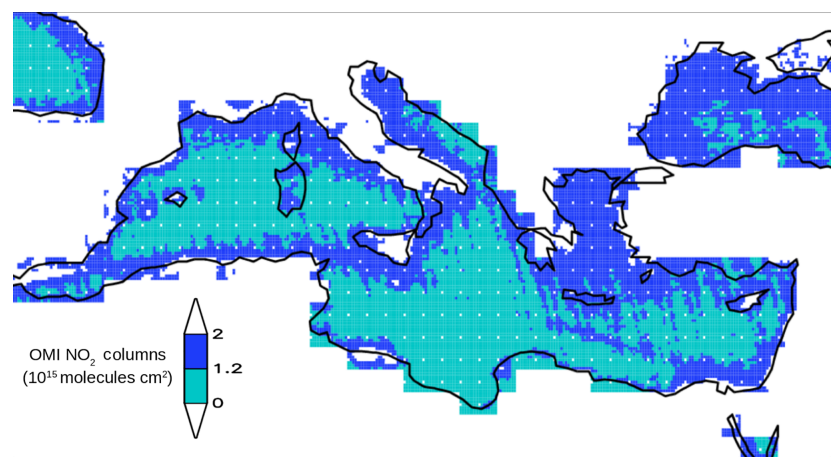

Figure 18. Seasonal average over June-August 2006 of OMI $\mathrm{NO}_{2}$ columns over the Mediterranean Sea $\left(10^{15}\right.$ molecules $\left.\mathrm{cm}^{-2}\right)$, retrieved from the OMI satellite and considering only maritime pixels (reproduced from Marmer et al., 2009).

The HONO mixing ratios obtained clearly point at the typical diurnal cycle with nighttime maxima and daytime minima (Lammel and Cape, 1996).

Ranmar et al. (2002) addressed the dynamics of transboundary air pollution, where transportation emissions (such as $\mathrm{NO}_{x}$ and VOC) originating from Israeli major coastal sources impact the onshore mixing layer. Analysis of $\mathrm{NO}_{y}$ data (here, the sum of all nitrogen oxide species, excluding $\mathrm{N}_{2} \mathrm{O}$ ), collected from 1 June to 30 September for the years 1999 and 2000 at a monitoring station located in metropoli$\tan$ Tel Aviv, yielded an average of $24.5 \pm 15.1 \mathrm{ppbv}$. They noted the higher initial $\mathrm{NO}_{y}$ levels during the morning rush hour emissions that were subjected to a noticeable bleaching by the late morning sea breeze in comparison to inland locations, which leveled off at relatively higher midday concentrations. Ranmar et al. (2002) argued that this may indicate, in the absence of any alternative $\mathrm{NO}_{y}$ source, that the early morning $\mathrm{NO}_{x}$ produced by transportation sources in Tel Aviv is transported inland, providing additional $\mathrm{NO}_{y}$ to the regions along its path.

Besides cruises of research vessels, airborne campaigns, and ground truth measurements, satellite-borne initiatives have been undertaken to get better insight into the reactive nitrogen concentrations over the EM. Marmer et al. (2009) used OMI (Boersma et al., 2004) as an observation tool to measure atmospheric $\mathrm{NO}_{2}$ column concentrations in order to validate ship emission inventories over the Mediterranean Basin. Figure 18 shows the average $\mathrm{OMI} \mathrm{NO}_{2}$ tropospheric columns (gridded to $0.125^{\circ} \times 0.125^{\circ}$ ) over the Mediterranean Sea for June-August 2006. The most prominent feature here is the elevated $\mathrm{NO}_{2}$ monthly mean. Under cloud-free conditions, typical values ranged from 1.2 to $2.0 \times$ $10^{15}$ molecules $\mathrm{cm}^{-2}$ over the northeastern African coast, the EM coast, the southern coast of Turkey, and the whole Aegean Sea, as compared to over $6 \times 10^{15}$ molecules $\mathrm{cm}^{-2}$ for European inland congested regions. Based on $\mathrm{OMI} \mathrm{NO}$ tropospheric columns and the Goddard Earth Observing 
System chemistry-transport (GEOS-Chem) model, Vinken et al. (2014) attributed the elevated $\mathrm{NO}_{2}$ column regions over the Mediterranean to $\mathrm{NO}_{2}$ emissions along ship tracks.

\subsection{Carbon monoxide sources and pathways}

$\mathrm{CO}$ has a global-average lifetime of about 2 months in the troposphere and its molecular weight is close to that of air. This molecule is considered as an excellent tracer for pollution sources and pollution pathways through the troposphere. In addition to production by chemical oxidation in the atmosphere, $\mathrm{CO}$ is emitted by biomass burning, man-made sources, vegetation, and ocean. The $\mathrm{CO}$ seasonal cycle is mainly governed by the concentration of $\mathrm{OH}$ in the troposphere (Novelli et al., 1992) and is expected to be the lowest in the summer when photochemistry is active and the highest during late winter or spring.

An assessment of $\mathrm{CO}$ baseline concentration levels at the surface over the EM is presented based on few observational studies that have been conducted for this pollutant. As part of a comparative air quality study, $\mathrm{CO}$ was analyzed at $\mathrm{Pa}$ tras $\left(38.25^{\circ} \mathrm{N}, 21.74^{\circ} \mathrm{E}\right)$ and Volos $\left(39.36^{\circ} \mathrm{N}, 22.94^{\circ} \mathrm{E}\right)$, two Mediterranean Greek coastal urban sites (Riga-Karandinos and Saitanis, 2005). They observed an annual average hourly mean concentration of $1.14 \mathrm{ppm}$ over 1995-2003 at Volos as compared to $0.95 \mathrm{ppm}$ at Patras over 2001-2003. The diurnal pattern at both sites during summer showed that vehicle-induced emissions contribute significantly to $\mathrm{CO}$ levels, with peak concentrations of 1.14 and $0.96 \mathrm{ppm}$ measured at 09:00 UTC at Volos and Patras, respectively. Over the EM coast, hourly average $\mathrm{CO}$ measurements conducted by Saliba et al. (2006) in the city of Beirut $\left(33.89^{\circ} \mathrm{N}, 35.50^{\circ} \mathrm{E}\right)$, Lebanon, point at an average monthly $\mathrm{CO}$ concentration during summer of $1.05 \mathrm{ppm}$, similar to the concentrations observed at Volos and Patras, Greece (Riga-Karandinos and Saitanis, 2005).

$\mathrm{CO}$ concentrations were measured by Elbayoumi et al. (2014) from the autumn of 2011 through mid-2012 in the Gaza strip, in the southeastern coast of the EM as part of an exposure study to assess the effect of seasonal variation on the mean daily indoor-outdoor ratio at 12 schools located over the northern, central, and southern strips of Gaza. They observed a $6 \mathrm{~h}$ average daily outdoor $\mathrm{CO}$ concentrations of $0.96 \pm 0.91 \mathrm{ppm}$ for all the schools. They further reported that the outdoor $\mathrm{CO}$ concentration spanned from 0.10 to $2.46 \mathrm{ppm}$ with a mean of $0.88 \mathrm{ppm}$ for urban sites and from 0.10 to $2.71 \mathrm{ppm}$ with a mean of $1.02 \mathrm{ppm}$ for overpopulated sites along the Gaza strip.

Due to the key role CO plays in atmospheric chemistry, several chemistry-transport modeling studies were devoted to this subject. $\mathrm{CO}$ was measured and used as a tracer in such a model (Lelieveld and Dentener, 2000) during the summer 2001 MINOS campaign (Lelieveld et al., 2002). The model diagnosed $\mathrm{CO}$ from anthropogenic sources in different parts of Europe, North America, and Asia. Trajectory

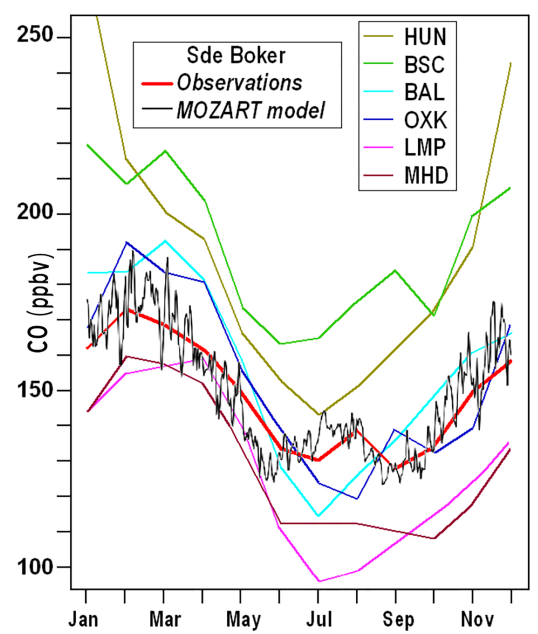

Figure 19. Monthly mean CO concentrations over 1996-2009 at Sde Boker (red) and at seven European ESRL/GMD background stations (listed in Table 3, multiple colors), compared to the 5year averaged $\mathrm{CO}$ surface concentrations at Sde Boker (black) over 2003-2007 from the MOZART-4 chemistry-transport model (adapted from Drori et al., 2012).

calculations in the lower troposphere identified western and eastern Europe as the main source emissions. Consequently, model simulations were performed for August 2001 over Sardinia $\left(40^{\circ} \mathrm{N}, 8^{\circ} \mathrm{E}\right)$ in the western Mediterranean and over Crete $\left(35^{\circ} \mathrm{N}, 25^{\circ} \mathrm{E}\right)$. Considering the negligible impact of local pollution sources, the high CO levels observed over Crete, in excess of $150 \mathrm{ppbv}$, were surprising. The model results indicated that regions surrounding the Mediterranean such as southern Italy, Greece, Serbia, Macedonia, the Middle East, and north Africa contribute relatively little to the CO pollution, typically about $20 \%$. Furthermore, Lelieveld et al. (2002) found that the EM is affected by CO-polluted air emitted from eastern Europe, Poland, Ukraine, and Russia. This pollution flow, east of the Carpathian Mountains, is channeled over the Black Sea and the Aegean Sea, and contributes 60 to $80 \%$ of the boundary-layer CO over the EM. Their model results are consistent with aircraft measurements, showing that the entire Mediterranean lower troposphere is polluted.

In the free EM troposphere, where westerly winds predominate, they revealed quite a different situation as compared to concentrations measured within the MLD. The midtropospheric $\mathrm{CO}$ measurements were $\sim 75-80 \mathrm{ppbv}$. From their model tracer analysis, the largest contribution over the Mediterranean is found originating from Asia (40 to 50\%). The CO typical lifetime ( $\sim 2$ months) enables air mass to circumnavigate the globe, which results in a low variability of its concentrations. Lelieveld et al. (2002) found that contributions by pollution from western and eastern Europe to mid-tropospheric CO were only about $10 \%$. 
Table 3. Locations and elevations of NOAA Earth System Research Laboratory Global Monitoring Division (ESRL/GMD) background sites for CO measurements plotted in Fig. 19.

\begin{tabular}{llrrrl}
\hline Code & Name & Lat. $\left({ }^{\circ} \mathrm{N}\right)$ & Long. $\left({ }^{\circ} \mathrm{E}\right)$ & Elev. $(\mathrm{m})$ & Country \\
\hline WIS & WIS station Negev Desert & 31.13 & 34.88 & 400.0 & Israel \\
HUN & Hegyhátsál & 46.95 & 16.65 & 248.0 & Hungary \\
LMP & Lampedusa & 35.52 & 12.62 & 45.0 & Italy \\
BSC & Black Sea Constanta & 44.17 & 28.68 & 3.0 & Romania \\
OXK & Ochsenkopf & 50.03 & 11.80 & 1022.0 & Germany \\
BAL & Baltic Sea & 55.35 & 17.22 & 3.0 & Poland \\
MHD & Mace Head County Galway & 53.33 & -9.90 & 5.0 & Ireland \\
\hline
\end{tabular}

Drori et al. (2012) conducted a study to locate the various CO sources converging from Europe, north Africa, and the Middle East and quantify their respective contributions to the EM. Background CO concentrations are monitored regularly over the southern part of Israel in Sde Boker (Weizmann Institute of Science - WIS station Negev Desert: $31.13^{\circ} \mathrm{N}, 34.88^{\circ} \mathrm{E}$; $400 \mathrm{~m}$ a.s.1.) as part of the $\mathrm{Na}$ tional Oceanic and Atmospheric Administration (NOAA) Earth System Research Laboratory Global Monitoring Division (ESRL/GMD), which aims at representing the EM. While comparing the seasonal cycle of Sde Boker to other European ESRL/GMD background sites (see Table 3), one essential feature is eminent from their results (represented in Fig. 19): CO concentrations are high over winter months, decreasing abruptly during April, and increasing again from November. A second maximum is observed during August compared to July and September (Drori et al., 2012).

To get insight into the spatial distribution of $\mathrm{CO}$ concentrations over the EM, the version 4 Measurement of Pollution in the Troposphere (MOPITT) level-2 CO retrievals (Deeter et al., 2010) were employed by Drori et al. (2012) using a priori information based on the Model for OZone and Related chemical Tracers (MOZART-4) chemistry-transport model simulation climatology (Emmons et al., 2010). The averaging kernel profile obtained for a retrieval near the Sde Boker ESRL/GMD station shows that, during the day, the $900 \mathrm{hPa}$ retrieval sharply peaks at the same level, indicating that there is a good sensitivity to lower tropospheric concentration. The anomalous high concentration observed at the WIS ESRL/GMD Sde Boker station, and calculated by the MOZART-4 model during August (Fig. 19), might be limited to lower levels, and therefore averaging over several layers might hide this signal. Furthermore, Drori et al. (2012) compared the in situ measurements at Sde Boker and $\mathrm{CO}$ retrieved from MOPITT to MOZART-4 model results. CO sources included direct emissions and secondary production from hydrocarbons' oxidation, while CO sinks included a reaction with $\mathrm{OH}$ and dry deposition. The seasonal cycle of surface $\mathrm{CO}$ at Sde Boker simulated by MOZART and averaged for 5 consecutive years shows a similar pattern exhibiting $\mathrm{CO}$ concentration reaching a maximum in February and a second peak in mid-summer months (i.e., July and August) that surpasses those of the early summer (i.e., May-June) (Fig. 19).

To attribute the $\mathrm{CO}$ sources affecting the EM, Drori et al. (2012) partitioned these sources using a tagging method into five types: anthropogenic, biogenic, fire, chemical production, and ocean. The total $\mathrm{CO}$ concentration and specific contributions 2006-2007 time series of MOZART at the surface at $30^{\circ} \mathrm{N}$ and $33.75^{\circ} \mathrm{E}$ are shown in Fig. 20 where ocean sources' contributions are not shown (negligible). Both biogenic (green line) and biomass burning sources (red line) have a minor contribution. Biogenic sources are characterized by a distinct seasonal cycle with high contribution over winter and low daily variability. Biomass burning has no defined seasonal signature and contributes on an episodic event basis. $\mathrm{CO}$ from chemical production (orange) contributes substantially (50-80 ppbv) with a defined seasonal cycle: low during winter and autumn and high during summer indicated by a low daily variability. Anthropogenic sources were found to be the main contributor to the total $\mathrm{CO}$ (purple, 50-180 ppbv). As expected, their seasonal cycle is indicated by elevated winter concentrations decreasing during spring, slightly increasing during summer, and decreasing again during autumn. The daily variability is high and similar to the total $\mathrm{CO}$ daily variability. Comparing the daily variability of the various sources, Drori et al. (2012) concluded that anthropogenic sources mainly govern total $\mathrm{CO}$ daily variability over the EM.

To further attribute the $\mathrm{CO}$ surface daily variation, Drori et al. (2012) tagged the anthropogenic sources for the three northern continents, i.e., North America, Europe, and Asia. Figure 21 shows the results of these anthropogenic sources' attribution to the CO surface. European anthropogenic sources contribute substantially (10-80 ppbv) to local $\mathrm{CO}$ concentrations with the greatest daily variability all year round. Asian and North American sources are in the same order of magnitude (10-25 ppbv) with low daily variability during most of the year and very small variability during summer. Obviously, daily summer $\mathrm{CO}$ variations in the EM are mainly caused by European anthropogenic sources. The seasonal cycle of the European contribution is very similar to the seasonal cycle of total $\mathrm{CO}$, indicated by a high 


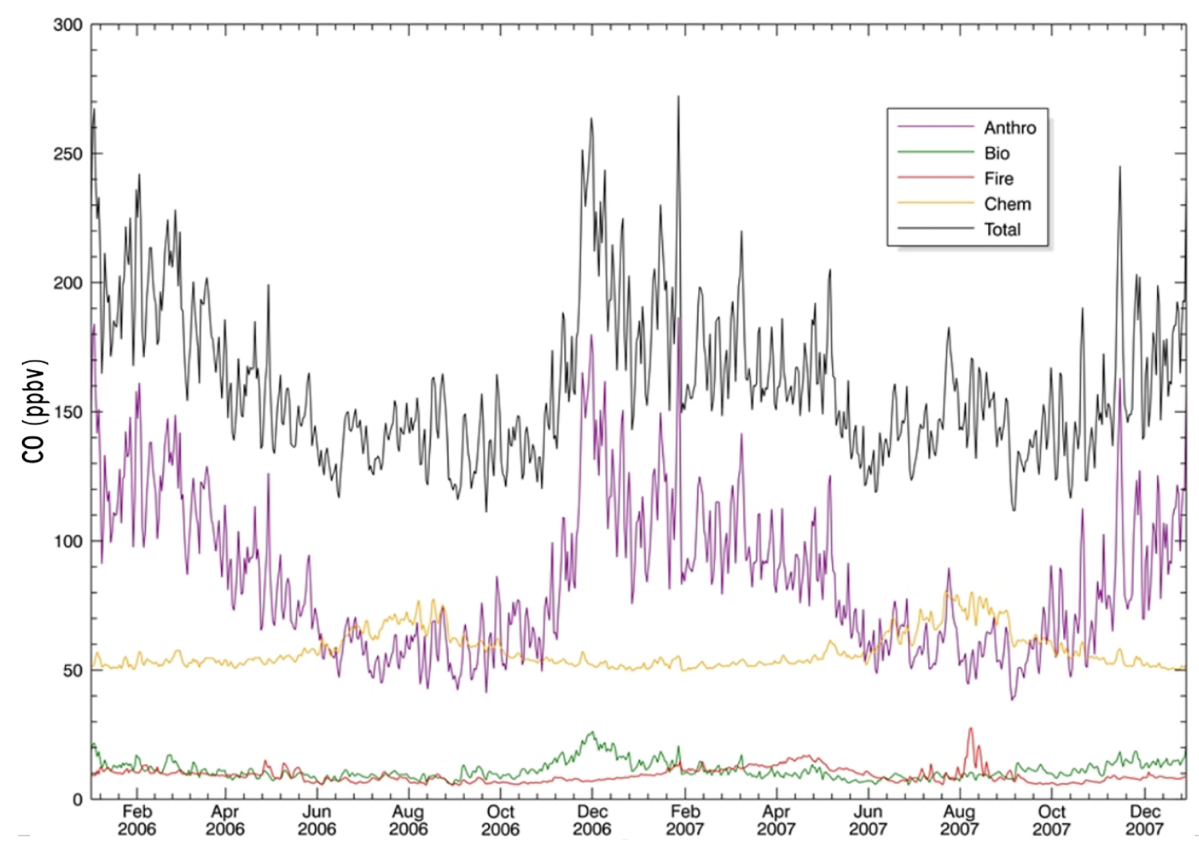

Figure 20. Monthly time series of total surface CO (black) at Sde Boker, Israel, and contributions from specific sources (anthropogenic in purple, chemical production in orange, biogenic in green, and fires in red; ocean is negligible and not shown) as simulated by MOZART for 2006-2007 (adapted from Drori et al., 2012).

concentration in winter, spring, and autumn and a lower summer concentration. The contribution of European emissions to $\mathrm{CO}$ surface concentrations is comparable to that from EM local emissions.

Drori et al. (2012) found, however, that local and European emission contributions to local $\mathrm{CO}$ concentrations are generally negatively correlated, meaning that either local or European sources are dominant, except during summer, when both sources simultaneously affect the local CO concentration. A possible reason for the positive summer correlation might be explained by the short range of air mass transport caused by the dominant summer synoptic system, i.e., the PT in its weak mode recirculating local and European emissions, and by the fact that summer chemical production is a major CO source over the EM.

Another recent modeling study focused on $\mathrm{CO}$ concentrations was conducted by Myriokefalitakis et al. (2016). They compared and validated model results against in situ observations at the surface, in the mixed layer, and in the free troposphere (between $850 \mathrm{hPa}$ and the tropopause) in the countryside and remote atmosphere over Europe for 2008. This study analyzes the total $\mathrm{CO}$ budget and the partial contribution of regional anthropogenic, biogenic, and biomass burning CO emissions in the EM. The budget calculated for 2008 in the EM mixed layer, using a basic simulation relying on anthropogenic emissions and meteorology, points at a load of $0.6 \mathrm{Tg}$ of $\mathrm{CO}$, a chemical production of $10 \mathrm{Tg} \mathrm{yr}^{-1}$, primary emissions in the region of $8 \mathrm{Tg} \mathrm{yr}^{-1}$, and a dry deposition flux of $3 \mathrm{Tg} \mathrm{yr}^{-1}$. Moreover, Myriokefalitakis et al. (2016) found that subsidence from higher atmospheric layers typifying the EM summer is an important CO source $\left(12 \mathrm{Tg} \mathrm{yr}^{-1}\right)$ in the EM free troposphere. At the surface, anthropogenic local emissions in the EM were found to contribute $18 \%$ to surface CO levels on an annual average. Over Cairo, out of the total surface $\mathrm{CO}$ concentration, roughly $32 \%$ are contributed by anthropogenic sources. These EM CO concentration results are consistent with previous modeling studies (e.g., Kanakidou et al., 2011; Drori et al., 2012; Im and Kanakidou, 2012).

\subsection{Methane concentrations}

$\mathrm{CH}_{4}$ is the most abundant hydrocarbon in the atmosphere with concentration originating from natural and anthropogenic sources. It is also the biggest contributor to GHG after water vapor and $\mathrm{CO}_{2}$ due to its high global warming potential relying on its infrared absorption and long atmospheric lifetime of $\sim 8$ years (Lelieveld et al., 1998), which allows its mixing throughout the atmosphere. $\mathrm{CH}_{4}$ emissions are primarily caused by microbiological decay of organic matter under depletion of dissolved oxygen in wetlands, followed by decomposition of solid waste and enteric fermentation from domestic livestock. As for the geologic sources, a total geological $\mathrm{CH}_{4}$ flux of $53 \pm 11 \mathrm{Tg} \mathrm{yr}^{-1}$ was suggested, which accounts for $7-10 \%$ of the total global $\mathrm{CH}_{4}$ budget (Etiope et al., 2008). The geological formations contributing to $\mathrm{CH}_{4}$ over the greater area of the $\mathrm{EM}\left(25-50^{\circ} \mathrm{N}, 5-55^{\circ} \mathrm{E}\right)$ are mud volcanoes with essential hot spots located over east- 


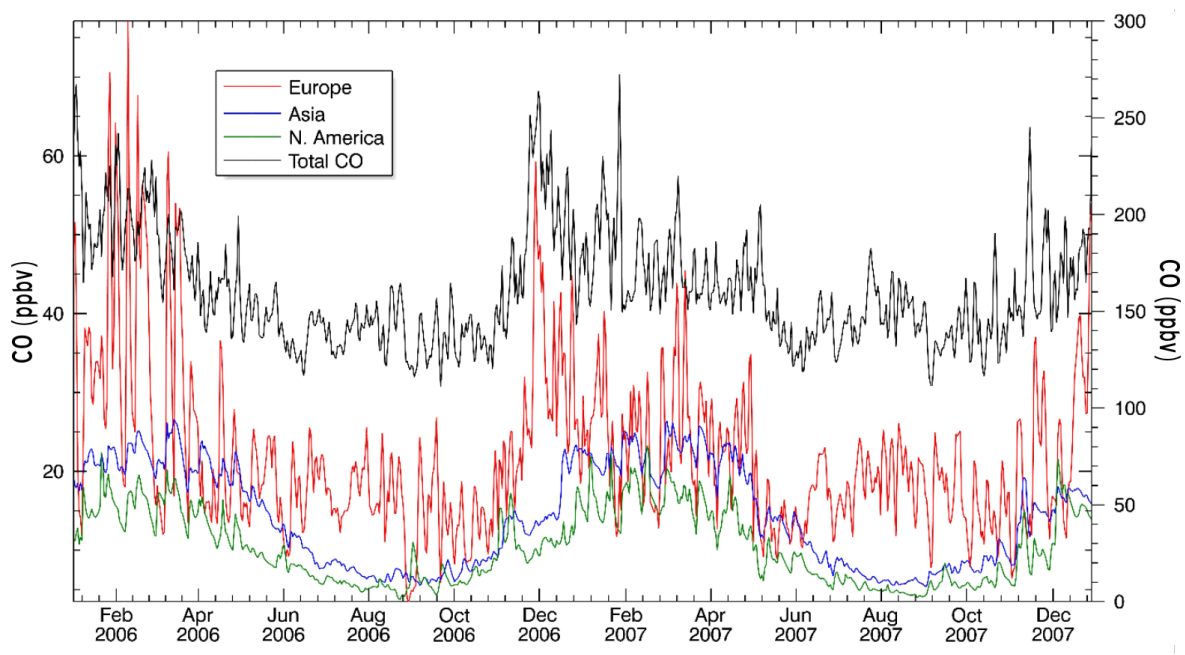

Figure 21. Monthly time series of the European (red), Asian (blue), and North American (green) anthropogenic contribution to the total surface CO (black) at Sde Boker as simulated by MOZART over 2006-2007. Distinct continents are scaled on the left vertical axis and total $\mathrm{CO}$ on the right vertical axis (adapted from Drori et al., 2012).

ern Romania, the Black Sea, central and eastern Azerbaijan, and the Caspian Sea.

In contrast to trace gases of short lifetimes such as $\mathrm{NO}_{x}$ and $\mathrm{NO}_{y}$, the long lifetime of $\mathrm{CH}_{4}$ over the EM may lead to interannual fluctuations of concentrations caused by circumglobal phenomena such as low-frequency global circulation patterns, i.e., the El Niño-Southern Oscillation (ENSO) and North Atlantic Oscillation (NAO), or changes in global temperature. Langenfelds et al. (2002) point at major biomass burning events linked to ENSO dry periods, which increased the growth rate of $\mathrm{CH}_{4}$ over other parts of the world. Artuso et al. (2007) compared the global average temperature anomaly to the growth rate of $\mathrm{CH}_{4}$ in Lampedusa $\left(35.5^{\circ} \mathrm{N}\right.$, $12.6^{\circ} \mathrm{E}$ ), Italy, for the period $1995-2005$. The 0.71 positive correlation they found reflects the strong relationship between these two factors. Over the EM, the NAO may possibly affect the concentration evolution through changes in the circulation (e.g., weakening of the northwesterly flow). However, so far, no association was found between the NAO index trend and the $\mathrm{CH}_{4}$ concentration growth over this part of the basin. The only study analyzing directly a possible association between the NAO index and $\mathrm{CH}_{4}$ concentration growth carried out by Chamard et al. (2003) in Lampedusa has not found any relationship between these two factors.

Satellite ability to monitor the concentration of trace gases in the atmosphere is important for completing the picture in regard to their budget. Among the space-borne measurements of trace gases, the Scanning Imaging Absorption Spectrometer for Atmospheric Cartography (SCIAMACHY) instrument was proven as a feasible tool to detect $\mathrm{CH}_{4}$ concentrations (Bovensmann et al., 1999). Measurements of column-average volume mixing ratios of $\mathrm{CH}_{4}$ were retrieved on a global basis (Frankerberg et al., 2005).
Georgoulias et al. (2011) used data from the SCIAMACHY instrument aboard the European environmental satellite (ENVISAT). SCIAMACHY's spectral near-infrared nadir measurements are sensitive to $\mathrm{CH}_{4}$ and $\mathrm{CO}_{2}$ concentration changes at all atmospheric altitudes, including the one in the mixed layer where the signal emitted from the surface source is the largest. Annual, seasonal, and monthly spatial distribution of $\mathrm{CH}_{4}$ were displayed for 2003 and 2004 based on the analysis of Weighting Function Modified Differential Optical Absorption Spectroscopy (WFM-DOAS) version 1.0 (Schneising et al., 2009) dry air column-averaged mole fractions, denoted as $\mathrm{XCH}_{4}$ (ppbv). The reflectivity of water surfaces is very low; therefore, Georgoulias et al. (2011) mapped the concentration of $\mathrm{CH}_{4}$ over the EM basin discarding the Mediterranean Sea. To reduce the noise inserted by the single pixel retrieval error and the temporal and spatial sparsity of the data, the data were averaged on $1^{\circ} \times 1^{\circ}$ monthly mean grids. Annual, summer, and August spatial distributions for 2003 are displayed in Fig. 22a, b, and c, respectively. Those maps illustrate an eminent seasonal variation with a summer maximum in $\mathrm{XCH}_{4}$ levels observed in both consecutive years (2004 not shown). The northeastern African coast exhibits the highest $\mathrm{XCH}_{4}$ values, with a hot spot over the Nile Delta in Egypt in summer and August. The lowest $\mathrm{XCH}_{4}$ levels along the Arabian Peninsula, the Zagros Mountains, and eastern Anatolia mountain barrier coincide spatially with high altitude areas. To examine to what extent the warm period affects the annual, seasonal, and latitudinal patterns, Georgoulias et al. (2011) further proceeded to a monthly analysis. They observed an increase in $\mathrm{XCH}_{4}$ levels during the summer season, with August being the month with the highest levels (1775-1780 \pm 24 ppbv) for both 2003 and 2004. The highest values are concentrated in 
(a) $\begin{array}{lllllllll}10 & 15 & 20 & 25 & 30 & 35 & 40 & 45 & 50\end{array}$

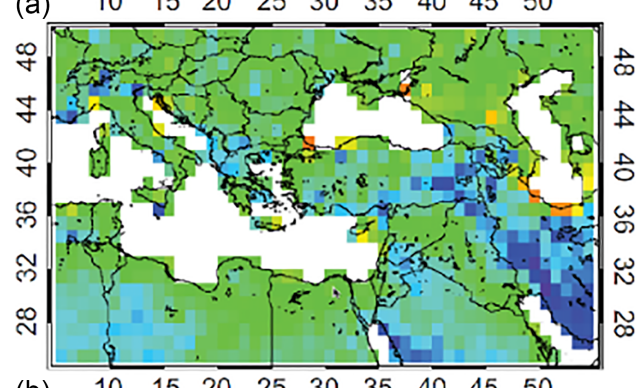

(b) $\begin{array}{llllllllll}10 & 15 & 20 & 25 & 30 & 35 & 40 & 45 & 50\end{array}$

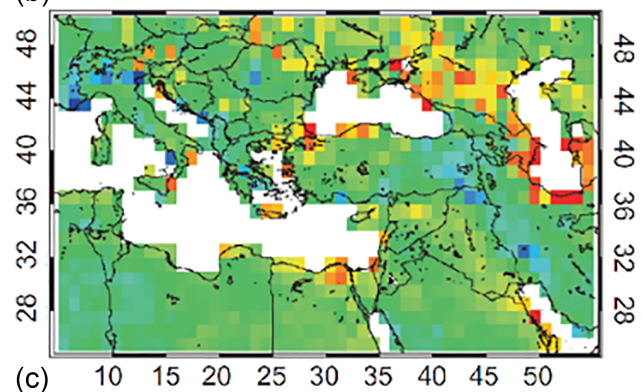

(c) $\begin{array}{lllllllllll}10 & 15 & 20 & 25 & 30 & 35 & 40 & 45 & 50\end{array}$

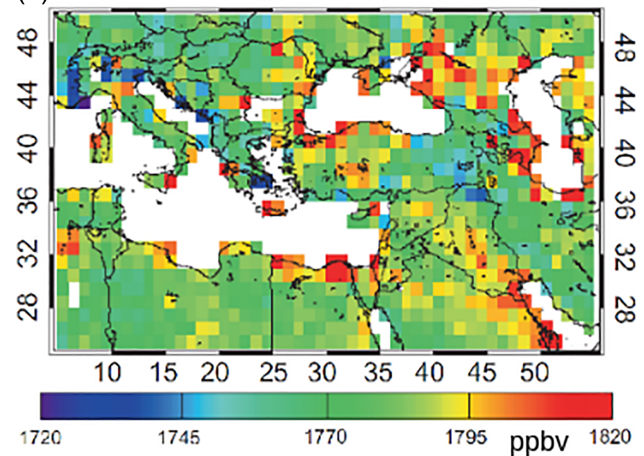

Figure 22. Maps by $1^{\circ} \times 1^{\circ}$ resolution of dry air column-averaged mole fractions, denoted as SCIAMACHY WFM-DOAS $\mathrm{XCH}_{4}$ levels, in 2003, including a yearly average (a), a summer average (b), and an August average (c) in ppbv (from Georgoulias et al., 2011; used with permission from Taylor and Francis).

the northeastern part of the area primarily in July-August. From July to September, there is a shift of high $\mathrm{XCH}_{4}$ levels from higher to lower latitudes. Despite the abundance of mud volcanoes over the greater area of the EM region, Georgoulias et al. (2011) ruled out the possibility that the $\mathrm{CH}_{4}$ total columns from SCIAMACHY (2003-2004) measured over these EM regions were attributed to volcano eruptions.

Ricaud et al. (2014) presented a thorough analysis of atmospheric $\mathrm{CH}_{4}$ distributions over the Mediterranean Basin in the troposphere, as part of the ChArMEx program, using both satellite measurements and model simulations. For this reason, they analyzed space-borne measurements from (i) the Thermal And Near infrared Sensor for carbon Observations - Fourier Transform Spectrometer (TANSO-FTS) instrument on the Greenhouse gases Observing SATellite (GOSAT), (ii) the Atmospheric InfraRed Spectrometer (AIRS) on the AURA platform, and (iii) the Infrared Atmospheric Sounder

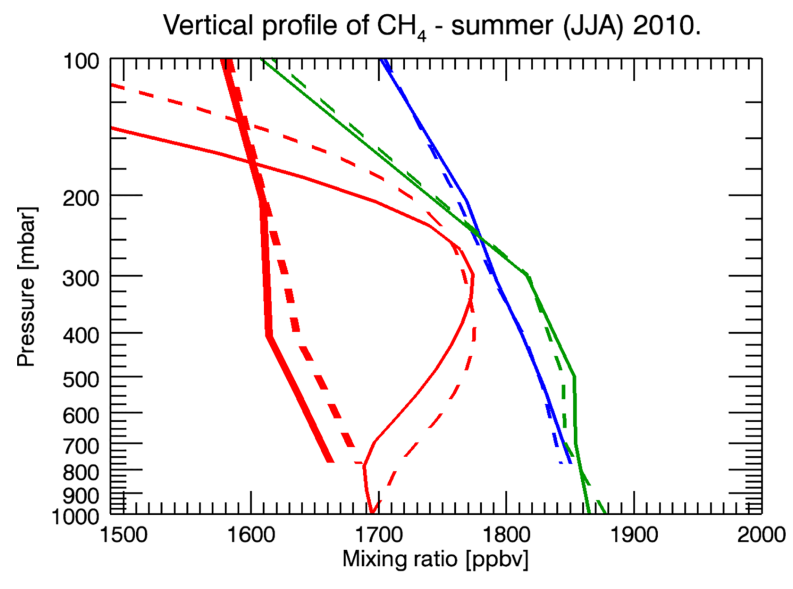

Figure 23. Summer averaged vertical profiles of $\mathrm{CH}_{4}$ as measured by AIRS (blue lines) and GOSAT (green lines), and as calculated by MOCAGE (thin red lines) over the eastern (dashed lines) and western (solid lines) Mediterranean basins in summer 2010. Also shown are the seasonally averaged MOCAGE profiles convolved with the AIRS averaging kernels (thick red lines) for the summer over the eastern (dashed lines) and western (solid lines) Mediterranean basins (adapted from Ricaud et al., 2014).

Interferometer (IASI) instrument aboard the MetOp-A platform. These space-borne tools were used in conjunction with the results obtained from three global models: the chemical transport model (CTM) MOCAGE (Teyssèdre et al., 2007) and the two chemical climate models (CCMs) CNRMAOCCM (Michou et al., 2011) and LMDz-OR-INCA (Hourdin et al., 2006). The sensitivity of those space-borne sensors is mainly located in the upper tropospheric layers, peaking around $300 \mathrm{hPa}$ with an envelope as defined by the half width at half maximum of the averaging kernels (see Fig. 23) from 400 to $200 \mathrm{hPa}$. Consequently, the comparisons between measurements and model outputs of $\mathrm{CH}_{4}$ are mainly concentrated on the layer around $300 \mathrm{hPa}$ for AIRS and GOSAT, or considering the total column for IASI.

In summer, the horizontal distribution of $\mathrm{CH}_{4}$ in the upper troposphere shows a clear longitudinal gradient between the east and the west of the Mediterranean Basin, both in the space-borne measurements and in the model calculations (Fig. 24). There is a maximum of $\mathrm{CH}_{4}$ in the eastern $\mathrm{MB}$ compared to the western $\mathrm{MB}$, both considering the upper tropospheric layer and the total column information. The difference between the east and the west of the MB has been calculated within all the datasets, and the seasonal variations have been investigated (Fig. 25). This clearly shows that the east-west difference peaks in summer, mainly in August.

The LRT conditions in the upper troposphere differ over both parts of the Mediterranean Basin. In the western part, whatever the season considered, air masses are basically coming from the west. However, in the EM, apart from the westerlies' influence, air masses are also originating from 
(a)

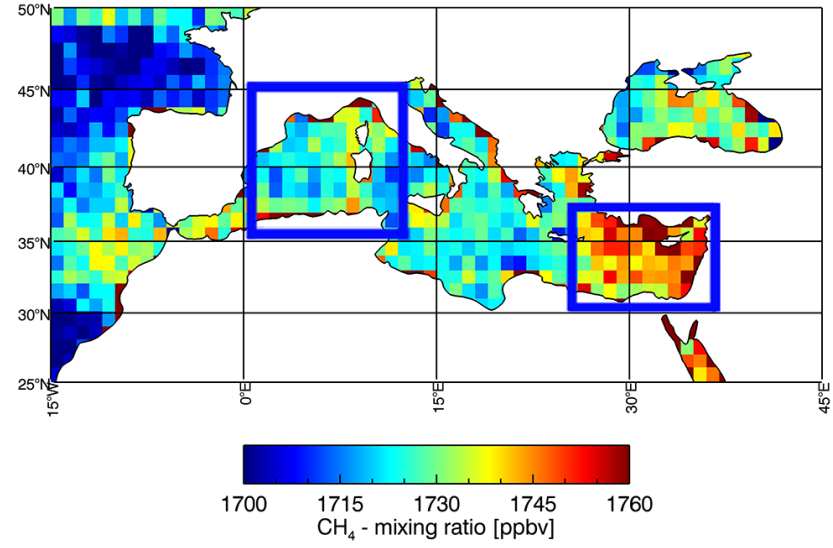

(c)

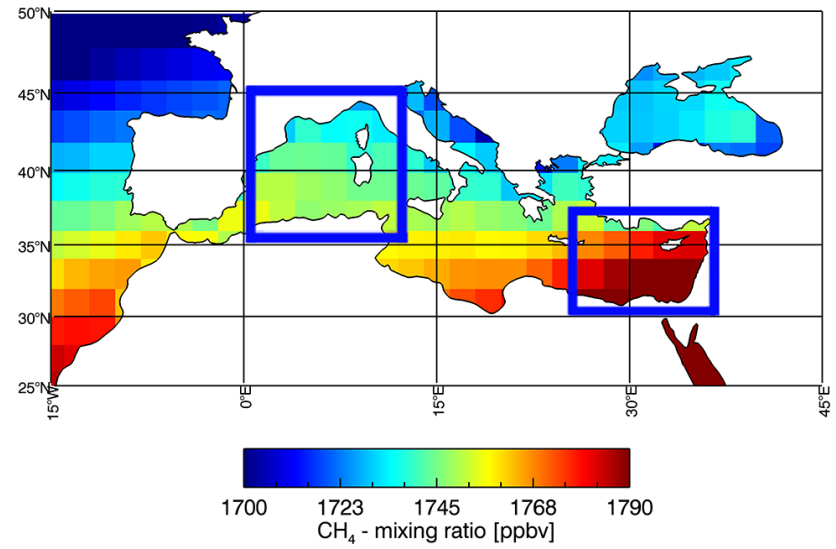

AIRS mixing ratio - summer (JJA) $2009 \mathrm{CH}_{4} @ 260$ mbar

(b)

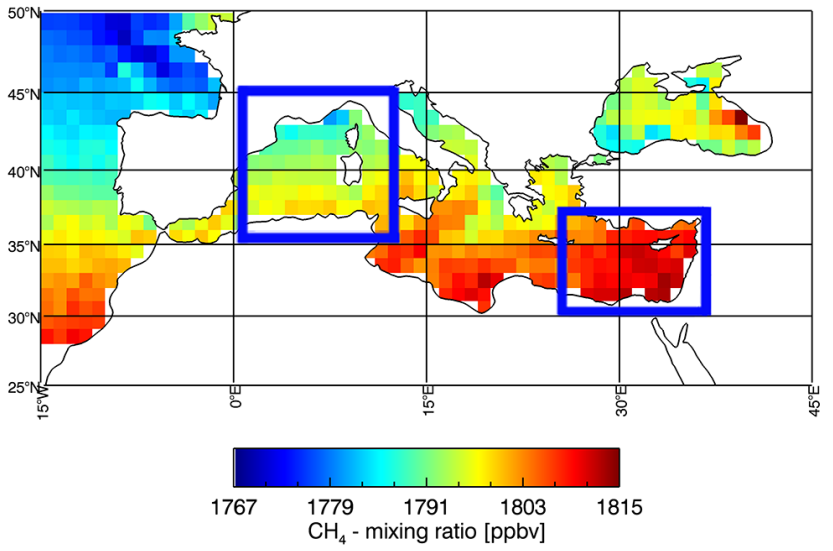

MOCAGE summer (JJA) 2009. $\mathrm{CH}_{4} @ 200$ hPa

(d)

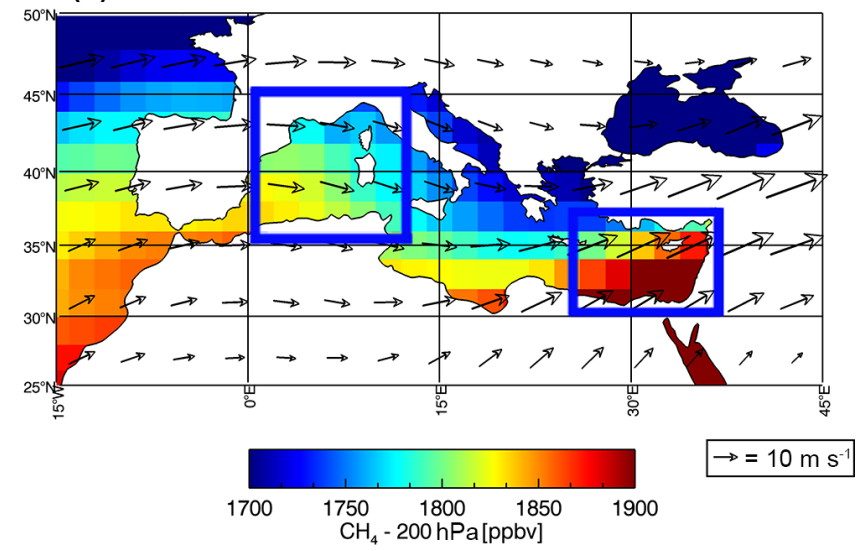

Figure 24. Fields of $\mathrm{CH}_{4}$ as calculated by MOCAGE (c, d) and as measured by IASI (a) in total column and AIRS (b) at $260 \mathrm{hPa}$ averaged for summer (July, July, August) 2009. Horizontal winds are from ARPEGE averaged over the same period. The two blue squares represent the western and eastern Mediterranean basins (adapted from Ricaud et al., 2014).
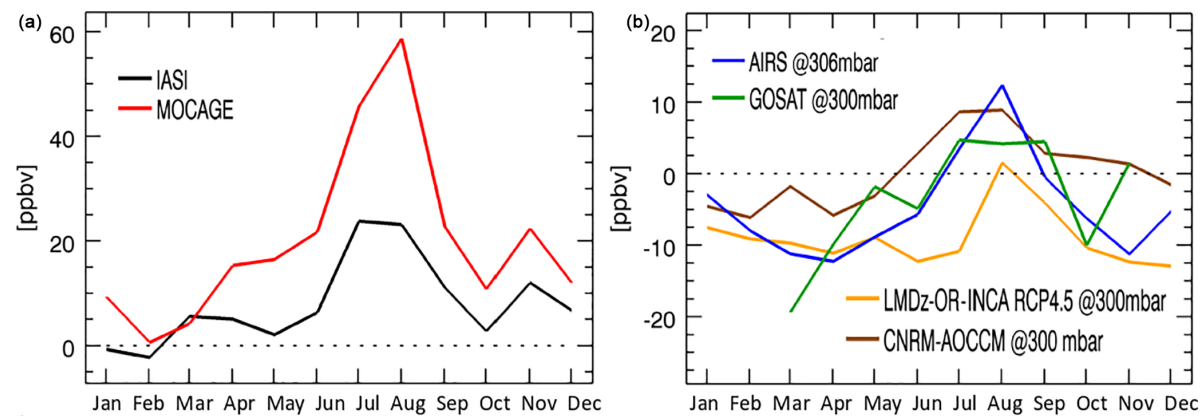

Figure 25. Seasonal evolution of the difference in $\mathrm{CH}_{4}$ fields between the eastern and western Mediterranean basins: (b) around $300 \mathrm{hPa}$ as measured by AIRS (blue) and GOSAT (green) and as calculated by LMDz-OR-INCA (yellow) and CNRM-AOCCM (brown), and (a) in the total column as measured by IASI and calculated by MOCAGE (adapted from Ricaud et al., 2014). 


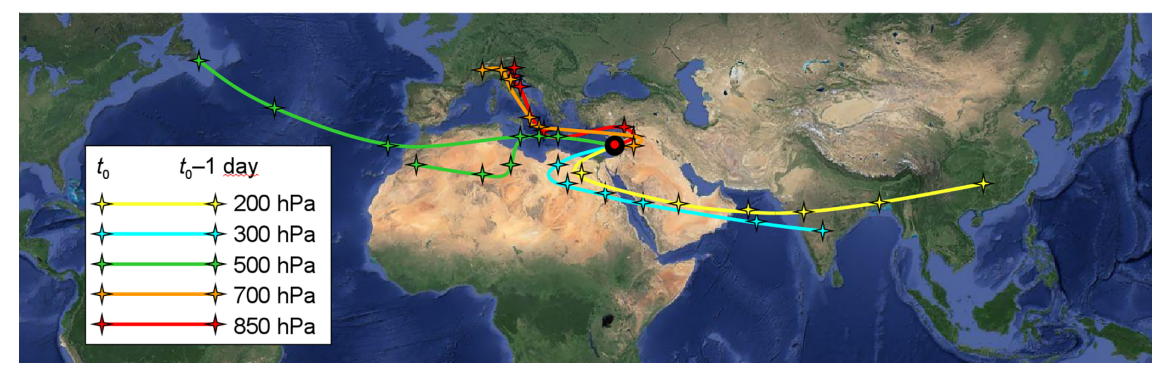

Figure 26. The 6-day back-trajectory climatology from the point at $33^{\circ} \mathrm{N}$ and $35^{\circ} \mathrm{E}$ located off Israel in the eastern Mediterranean Basin (red filled circle) derived for July-August over 2001-2010 every $12 \mathrm{~h}$. The position of the gravity center of each distribution (i.e., the maximum in the probability density function) at each level is represented every $24 \mathrm{~h}$ by a star (adapted from Ricaud et al., 2014).

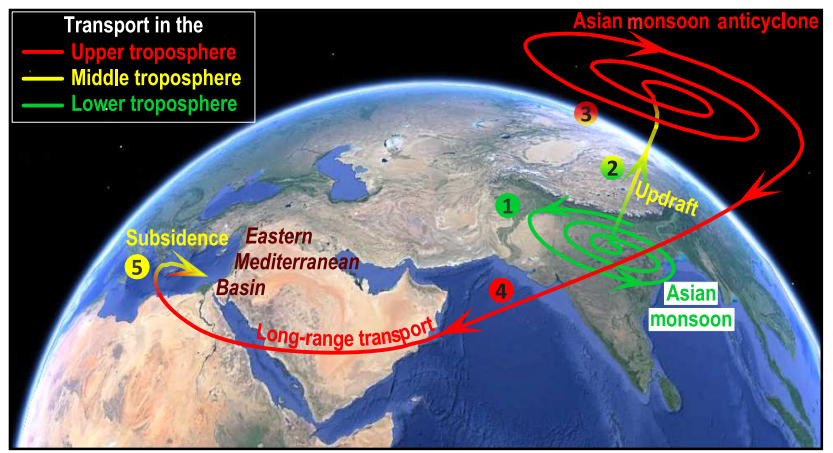

Figure 27. Schematic representation of the processes impacting the mid-to-upper tropospheric pollutants, including $\mathrm{CH}_{4}$ above the eastern Mediterranean in summer (July-August) (adapted from Ricaud et al., 2014).

northern Africa and the Arabian Peninsula (Ziv et al., 2004; Liu et al., 2009), and even farther away, from Asia.

To further examine the origin of air masses reaching the eastern MB, a 6-day back trajectory from the point at $33^{\circ} \mathrm{N}$, $35^{\circ} \mathrm{E}$, located in the EM (red filled circle in Fig. 26) was calculated, considering vertical movement, using the British Atmospheric Data Centre (BADC) trajectory service (http: //badc.nerc.ac.uk/community/trajectory/) every $12 \mathrm{~h}$ in JulyAugust over 2001-2010. The position of the gravity center of all trajectories (i.e., the maximum in the probability density function) is displayed every $24 \mathrm{~h}$ in Fig. 26 at 850 (red stars), 700 (orange), 500 (green), 300 (blue), and $200 \mathrm{hPa}$ (yellow). For this purpose, data from the ECMWF archive (spatial resolution of $2.5^{\circ}$ at the five standard pressure levels) were used in the calculation.

Based on these studies focused on the EM, Ricaud et al. (2014) proposed a scheme displaying the transport mechanism (Fig. 27) representing the several-stage process: (1) capturing of lower tropospheric pollutants, including $\mathrm{CH}_{4}$, in the Asian monsoon, (2) pollutants' ascent to the upper troposphere by the Asian monsoon, (3) accumulation of pollutants within the Asian monsoon in the upper troposphere, (4) long-range transport and large-scale repartition of pollutants in the upper troposphere from the Asian monsoon anticyclone to the Middle East and north Africa, (5) subsiding air masses yielding to the build-up of pollutants at midtropospheric layers above the EM.

\section{Conclusions and perspectives}

This review demonstrates the significant progress made in understanding the atmospheric pollution over the MB. Measurements from space-borne and aircraft instruments and outputs from chemistry-climate models and chemistrytransport models clearly revealed that the general atmospheric dynamic summer conditions characterizing the EM basin differ much from the western ones. The impact of the different meteorological regimes together with the seasonal variabilities of the emissions of various atmospheric pollutants results in a longitudinal concentration gradient between the eastern and western Mediterranean basins.

Several new campaigns have been recently organized to give more insight for the understanding of the processes occurring in the western and eastern parts of this basin in the framework of the ChArMEx program. The TRAnsport and Air Quality (TRAQA) campaign (Attié et al., 2014; Di Biagio et al., 2015; Sič et al., 2016) held in summer 2012 was dedicated to the export/import of pollutants from the European continent to the Mediterranean Sea by means of balloon and airborne measurements. The Aerosol Direct Radiative Impact in the Mediterranean (ADRIMED) campaign investigated aerosols of various origins and their optical properties over the western basin in summer 2013 (Mallet et al., 2016). The Secondary Aerosol Formation in the Mediterranean (SAFMED) campaigns focused on the organic reactive gases and aerosol over the northwestern basin and southeastern France in summer 2013 and 2014 (Di Biagio et al., 2015). Finally, the GLAM campaign (Ricaud et al., 2017) held in August 2014 was dedicated to the study of the gradient of chemical constituents (pollutants and GHGs) from Toulouse (France) to Larnaca (Cyprus) and the impact of the Asian monsoon anticyclone on the EM pollutant levels. 
Surface background stations in the EM (e.g., Crete, Greece, and Larnaca, Cyprus) and in the western Mediterranean Basin (e.g., Menorca, Spain, and Lampedusa, Italy) deployed even more instruments to obtain a wide variety of atmospheric parameters (meteorology, chemistry, dynamics, radiation, etc.). These campaigns were organized in a close relationship with modeling studies (forecasts and reanalyses) and space-borne observations. New airborne campaigns are under analysis, e.g., Oxydation Mechanism Observation (OMO) in summer 2015, or in progress (Radiative Impact of the Arabian Sea pollutants, greenhouse gases and aerosols on the eastern MEditerranean climate in Summer (RIMES) in summer 2019) in order to quantify the export of the Asian pollutants to the EM basin and its impact on the chemical constituent loading.

Concurrently to these intensive experiments, new sites have been instrumented. In early 2015, the Agia Marina Xyliatou EMEP rural background air quality station located at $532 \mathrm{~m}$ altitude in the center of Cyprus $\left(35.03^{\circ} \mathrm{N}\right.$, $33.05^{\circ} \mathrm{E}$ ), and operated since October 1996 (Kleanthous et al., 2014), has been augmented with a package of atmospheric chemistry and physics monitoring instruments, thanks to the Cyprus Institute and French laboratories, in order to initiate an enhanced atmospheric chemistry observation period of several years in the easternmost Mediterranean Basin. Unmanned aircraft vehicles are also deployed on a regular basis to document the lower troposphere above the station, and the German Leibniz Institute for Tropospheric Research (TROPOS) institute has deployed a full set of aerosol-cloud-water vapor remote sensing instruments for almost a year in October 2016. This unprecedented experimental effort is expected to bring information on the variability of new compounds and processes with a focus on VOCs and secondary and carbonaceous aerosols and their origins, and on interactions between aerosols and the water vapor cycle in this region.

Data availability. NCEP reanalysis data provided by the NOAA/OAR/ESRL PSD, Boulder, Colorado, USA, for the period 1948-2016 were used to calculate the composite long-term mean of sea-level pressure, temperature at $850 \mathrm{hPa}$, wind vectors, relative humidity, relative vorticity at $200 \mathrm{hPa}$, and omega at the $500 \mathrm{hPa}$ and $700 \mathrm{hPa}$ levels; these data are available at http://www.esrl.noaa.gov/psd/.

Competing interests. The authors declare that they have no conflict of interest.

Special issue statement. This article is part of the special issue "CHemistry and AeRosols Mediterranean EXperiments (ChArMEx) (ACP/AMT inter-journal SI)”. It is not associated with a conference.
Acknowledgements. We would like to thank two anonymous reviewers for their valuable and insightful comments, and Eric Hamonou for his efficient assistance in taking care of the copyright permission process. The first author is grateful for the partial funding from CNRS, France, for carrying out this study in the framework of the Chemistry-Aerosol Mediterranean Experiment (ChArMEx) program and for the hosting granted by Météo-France in the initiation of the program.

Edited by: Nikolaos Mihalopoulos

Reviewed by: three anonymous referees

\section{References}

Akritidis, D., Zanis, P., Pytharoulis, I., Mavrakis, A., and Karacostas, Th.: A deep stratospheric intrusion event down to the earth's surface of the megacity of Athens, Meteorol. Atmos. Phys., 109, 9-18, https://doi.org/10.1007/s00703-010-0096-6, 2010.

Akritidis, D., Pozzer, A., Zanis, P., Tyrlis, E., Škerlak, B., Sprenger, M., and Lelieveld, J.: On the role of tropopause folds in summertime tropospheric ozone over the eastern Mediterranean and the Middle East, Atmos. Chem. Phys., 16, 14025-14039, https://doi.org/10.5194/acp-16-14025-2016, 2016.

Alper-Siman Tov, D., Peleg, M., Matveev, V., Mahrer, Y., Seter, I., and Luria, M.: Recirculation of polluted air masses over the east Mediterranean coast, Atmos. Environ., 31, 1441-1448, https://doi.org/10.1016/S1352-2310(96)00321-4, 1997.

Amaroso, A., Beine, H. J., Esposito, G., Perrino, C., Catrambone, M., and Allegrini, I.: Seasonal differences in atmospheric nitrous acid near Mediterranean urban areas, Water Air Soil Poll., 188, 81-92, https://doi.org/10.1007/s11270-007-9526-6, 2008.

Anagnostopoulou, C., Zanis, P., Kratagkou, E., Tegoulias, I., and Tolika, K.: Recent past and future patterns of the Etesian winds based on regional scale climate model simulations, Clim. Dynam., 42, 1819-1836, https://doi.org/10.1007/s00382-013-19360,2014 .

Andreae, M. O.: The dark side of aerosols, Nature, 409, 671-672, https://doi.org/10.1038/35055640, 2001

Artuso, F., Chamard, P., Piacentino, S., di Sarra, A., Meloni, D., Monteleone, F., Sferlazzo, D. M., and Thiery, F.: Atmospheric methane in the Mediterranean: analysis of measurements at the island of Lampedusa during 1995-2005, Atmos. Environ., 41, 3877-3888, https://doi.org/10.1016/j.atmosenv.2007.01.024, 2007.

Attié, J. L., Ravetta, F., Durand, P., El Amraoui, L., Di Biaggio, C., Dulac, F., Sicard, M., Renard, J. B., Fleury, L., Bourdon, A., Verdier, N., and the TRAQA/ChArMEx Team: Transport of Pollution and Air Quality experiment over the Mediterranean basin (TRAQA/ChArMEx campaign), Geophys. Res. Abstr., EGU2014-12125, EGU General Assembly 2014, Vienna, Austria, 2014.

Bardouki, H., Berresheim, H., Vrekoussis, M., Sciare, J., Kouvarakis, G., Oikonomou, K., Schneider, J., and Mihalopoulos, $\mathrm{N}$.: Gaseous (DMS, MSA, $\mathrm{SO}_{2}, \mathrm{H}_{2} \mathrm{SO}_{4}$ and DMSO) and particulate (sulfate and methanesulfonate) sulfur species over the northeastern coast of Crete, Atmos. Chem. Phys., 3, 1871-1886, https://doi.org/10.5194/acp-3-1871-2003, 2003a. 
Bardouki, H., Liakakou, H., Economou, C., Smolik, J., Zdimal, V., Eleftheriadis, K., Lazaridis, M., and Mihalopoulos, N.: Chemical composition of size resolved atmospheric aerosols in the eastern Mediterranean during summer and winter, Atmos. Environ., 37, 195-208, https://doi.org/10.1016/S1352-2310(02)00859-2, 2003b.

Barkan, J. and Feliks, Y.: Observations of the diurnal oscillation of the inversion over the Israeli coast, Bound.-Lay. Meteorol., 62, 393-409, https://doi.org/10.1007/BF00705568, 1993.

Boersma, K. F., Eskes, H. J., and Brinksma, E. J.: Error analysis for tropospheric $\mathrm{NO}_{2}$ retrieval from space, J. Geophys. Res.-Atmos., 109, D04311, https://doi.org/10.1029/2003JD003962, 2004.

Bovensmann, H., Burrows, J. P., Buchwitz, M., Frerick, J., Noel, S., Rozanov, V. V., Chance, K. V., and Goede, A. P. H.: SCIAMACHY: mission objectives and measurement modes, J. Atmos. Sci., 56, 127-150, https://doi.org/10.1175/15200469(1999)056<0127:SMOAMM>2.0.CO;2, 1999.

Businger, J. A. and Charnock, H.: Boundary layer structure in relation to larger-scale flow: some remarks on the JASIN observations, Philos. T. R. Soc. Lond. A, 308, 1503, 445-449, 1983.

Chamard, P., Thiery, F., di Sarra, A., Ciattaglia, L., De Silvestri, L., Grigrioni, P., Monteleone, F., and Piacentino, S.: Interannual variability of atmospheric $\mathrm{CO}_{2}$ in the Mediterranean: measurements at the island of Lampedusa, Tellus B, 55, 83-93, https://doi.org/10.1034/j.1600-0889.2003.00048.x, 2003.

Chin, M., Rood, R. B., Lin, S. J., Muller, J. F., and Thompson, A. M.: Atmospheric sulfur cycle simulated in the global model GOCART: model description and global properties, J. Geophys. Res.-Atmos., 105, 24671-24687, https://doi.org/10.1029/2000JD900384, 2000.

Cohen, R. C., Perkins, K. K., Koch, L. C., Stimpfle, R. M., Wennberg, P. O., Hanisco, T. F., Lanzendorf, J. E., Bonne, G. P., Voss, P. B., Salawitch, R. J., Del Negro, L. A., Wilson, J. C., McElroy, C. T., and Bui, T. P.: Quantitative constraints on the atmospheric chemistry of nitrogen oxides: an analysis along chemical coordinates, J. Geophys. Res.-Atmos., 105, 24283-24304, https://doi.org/10.1029/2000JD900290, 2000.

Corbett, J. J., Fischbeck, P. S., and Panis, S. N.: Global nitrogen and sulfur inventories for oceangoing ships, J. Geophys. Res.-Atmos., 104, 3457-3470, https://doi.org/10.1029/1998JD100040, 1999.

Dastoor, A. P. and Larocque, Y.: Global circulation of atmospheric mercury: a modeling study, Atmos. Environ., 38, 147161, https://doi.org/10.1016/j.atmosenv.2003.08.037, 2004.

Davis, R. E. and Kalkstein, L. S.: Using a spatial synoptic classification to assess changes in atmospheric pollution concentrations, Phys. Geogr., 11, 320-342, 1990.

Dayan, U.: Climatology of back trajectories from Israel based on synoptic analysis, J. Clim. Appl. Meteorol., 25, 591-595, https://doi.org/10.1175/15200450(1986)025<0591:COBTFI>2.0.CO;2, 1986.

Dayan, U. and Graber, M.: Analysis of synoptic conditions in the eastern Mediterranean that led to elevated air pollution concentration in Israel, in: Developments in Arid Zone Ecology and Environmental Quality, edited by: Shuval, H. I., Balaban International Science Services, PA, 383-391, 1981.

Dayan, U. and Koch, J.: Ozone concentration profiles in the Los Angeles Basin - a possible similarity in the build-up mechanism of inland surface ozone in Israel, J.
Appl. Meteorol., 35, 1085-1090, https://doi.org/10.1175/15200450(1996)035<1085:OCPITL>2.0.CO;2, 1996.

Dayan, U. and Levy, I.: Relationship between synopticscale atmospheric circulation and ozone concentrations over Israel, J. Geophys. Res.-Atmos., 107, 4813, https://doi.org/10.1029/2002JD002147, 2002.

Dayan, U. and Rodnizki, J.: The temporal behavior of the atmospheric boundary layer in Israel, J. Appl. Meteorol., 38, 830-836, https://doi.org/10.1175/15200450(1999)038<0830:TTBOTA>2.0.CO;2, 1999.

Dayan, U., Shenhav, R., and Graber, M.: The spatial and temporal behavior of the mixed layer in Israel, J. Appl. Meteorol., 27, 1382-1394, https://doi.org/10.1175/15200450(1988)027<1382:TSATBO>2.0.CO;2, 1988.

Dayan, U., Heffter, J., Miller, J., and Gutman, G.: Dust intrusion events into the Mediterranean Basin, J. Appl. Meteorol., 30, 1185-1199, https://doi.org/10.1175/15200450(1991)030<1185:DIEITM>2.0.CO;2, 1991.

Dayan, U., Heffter, J., and Miller, J.: Seasonal distribution of the boundary layer depths over the Mediterranean Basin, in: The Impact of Desert Dust Across the Mediterranean, edited by: Guerzoni, S., Chester, R., Kluwer, Dordrecht, 103-112, 1996.

Dayan, U., Lifshitz-Goldreich, B., and Pick, K.: Spatial and structural variation of the atmospheric boundary layer during summer in Israel-Profiler and rawinsonde measurements, J. Appl. Meteorol., 41, 447-457, https://doi.org/10.1175/15200450(2002)041<0447:SASVOT>2.0.CO;2, 2002.

Dayan, U., Ziv, B., Shoob, T., and Enzel, Y.: Suspended dust over southeastern Mediterranean and its relation to atmospheric circulations, Int. J. Climatol., 28, 915-924, https://doi.org/10.1002/joc.1587, 2008.

Dayan, U., Erel, Y., Shpund, J., Kordova, L., Wanger, A., and Schauer, J. J.: The impact of local sources and meteorological factors on nitrogen oxide and particulate matter concentrations: a case study of the Day of Atonement in Israel, Atmos. Environ., 45, 3325-3332, https://doi.org/10.1016/j.atmosenv.2011.02.017, 2011.

Deeter, M. N., Edwards, D. P., Gille, J. C., Emmons, L. K., Francis, G., Ho, S.-P., Mao, D., Masters, D., Worden, H., Drummond, J. R., and Novelli, P. C.: The MOPITT Version 4 CO Product: algorithm enhancements, validation, and long-term stability, J. Geophys. Res.-Atmos., 115, D07306, https://doi.org/10.1029/2009JD013005, 2010.

Di Biagio, C., Doppler, L., Gaimoz, C., Grand, N., Ancellet, G., Raut, J.-C., Beekmann, M., Borbon, A., Sartelet, K., Attié, J.-L., Ravetta, F., and Formenti, P.: Continental pollution in the western Mediterranean basin: vertical profiles of aerosol and trace gases measured over the sea during TRAQA 2012 and SAFMED 2013, Atmos. Chem. Phys., 15, 9611-9630, https://doi.org/10.5194/acp-15-9611-2015, 2015.

Dobbins, R. A.: Atmospheric Motion and Air Pollution, Wiley, Environmental Science and Technology Series, p. 323, 1979.

Doche, C., Dufour, G., Foret, G., Eremenko, M., Cuesta, J., Beekmann, M., and Kalabokas, P.: Summertime troposphericozone variability over the Mediterranean basin observed with IASI, Atmos. Chem. Phys., 14, 10589-10600, https://doi.org/10.5194/acp-14-10589-2014, 2014.

Drori, R., Dayan, U., Edwards, D. P., Emmons, L. K., and Erlick, C.: Attributing and quantifying carbon monoxide sources affecting 
the Eastern Mediterranean: a combined satellite, modelling, and synoptic analysis study, Atmos. Chem. Phys., 12, 1067-1082, https://doi.org/10.5194/acp-12-1067-2012, 2012.

Elbayoumi, M., Ramli, N. A., Faizah, N., and Al-Madhoun, W.: The effect of seasonal variation on indoor and outdoor carbon monoxide concentrations in Eastern Mediterranean climate, Atmos. Pollut. Res., 5, 315-324, https://doi.org/10.5094/APR.2014.037, 2014.

Emmons, L. K., Carroll, M. A., Hauglustaine, D. A., Brasseur, G. P., Atherton, C., Penner, J., Sillman, S., Levy II, H., Rohrer, F., Wauben, W. M. F., Van Velfthoven, P. F. J., Wang, Y., Jacob, D., Bakwin, P., Dickerson, R., Doddridge, B., Gerbig, C., Honrath, R., Hubler, G., Jaffe, D., Kondo, Y., Munger, J. W., Torres, A., and Voltz-Thomas, A.: Climatologies of $\mathrm{NO}_{x}$ and $\mathrm{NO}_{y}$ : a comparison of data and models, Atmos. Environ., 31, 18511904, https://doi.org/10.1016/S1352-2310(96)00334-2, 1997.

Emmons, L. K., Walters, S., Hess, P. G., Lamarque, J.-F., Pfister, G. G., Fillmore, D., Granier, C., Guenther, A., Kinnison, D., Laepple, T., Orlando, J., Tie, X., Tyndall, G., Wiedinmyer, C., Baughcum, S. L., and Kloster, S.: Description and evaluation of the Model for Ozone and Related chemical Tracers, version 4 (MOZART-4), Geosci. Model Dev., 3, 43-67, https://doi.org/10.5194/gmd-3-43-2010, 2010.

Erel, Y., Axelrod, T., Veron, A., Mahrer, Y., and Dayan, U.: Transboundary atmospheric lead pollution, Environ. Sci. Technol., 36, 3230-3233, https://doi.org/10.1021/es020530q, 2002.

Erel, Y., Kalderon-Asael, B., Dayan, U., and Sandler, A.: European pollution imported by cooler air masses to the eastern Mediterranean during the summer, Environ. Sci. Technol., 41, 51985203, https://doi.org/10.1021/es062247n, 2007.

Erel, Y., Tirosh, O., Kessler, N., Dayan, U., Belkin, S., Stein, M., Sandler, A., and Schauer, J. J.: Atmospheric particulate matter (PM) in the Middle East: toxicity, transboundary transport, and influence of synoptic conditions, in: Medical Geochemistry: Geological Materials and Health, edited by: Censi, P., Darrah, T., Erel, Y., Springer, Dordrecht, https://doi.org/10.1007/978-94007-4372-4_3, 2013.

Etiope, G., Lassey, K. R., Lusman, K., and Oschi, B.: Reappraisal of the fossil methane budget and related emission from geologic sources, Geophys. Res. Lett., 35, L09307, https://doi.org/10.1029/2008GL033623, 2008.

Fleming, Z. L., Monks, P. S., and Manning, A. J.: Review: Untangling the influence of air-mass history in interpreting observed atmospheric composition, Atmos. Res., 104-105, 1-39, https://doi.org/10.1016/j.atmosres.2011.09.009, 2012.

Frankenberg, C., Meirink, J. F., van Weele, M., Platt, U., and Wagner, T.: Assessing Methane emissions from global space-borne observations, Science, 308, 1010-1014, https://doi.org/10.1126/science.1106644, 2005.

Galani, E., Balis, D., Zanis, P., Zerefos, C., Papayannis, A., Wernli, H., and Gerasopoulos, E.: Observations of stratospheretroposphere transport events over the eastern Mediterranean using a ground-based lidar system, J. Geophys. Res.-Atmos., 108, 8527, https://doi.org/10.1029/2002JD002596, 2003.

Gamo, M., Yamamoto, S., and Yokoyama, O.: Airborne measurements of the free convective internal boundary layer during the sea breeze, J. Meteorol. Soc. Jpn., 60, 1284-1298, 1982.

Ganor, E., Levin, Z., and Van Grieken, R.: Composition of individual aerosol particles above the Israelian Mediterranean coast during the summer time, Atmos. Environ., 32, 1631-1642, https://doi.org/10.1016/S1352-2310(97)00397-X, 1998.

Ganor, E., Foner, H. A., Bingemer, H. G., Udisti, R., and Setter, I.: Biogenic sulphate generation in the Mediterranean Sea and its contribution to the sulphate anomaly in the aerosol over Israel and the Eastern Mediterranean, Atmos. Environ., 34, 3453-3462, https://doi.org/10.1016/S1352-2310(00)00077-7, 2000.

Georgoulias, A. K., Kourtidis, K. A., Buchwitz, M., Schneising, O., and Burrows, J. P.: A case study on the application of SCIAMACHY satellite methane measurements for regional studies: the greater area of the Eastern Mediterranean, Int. J. Remote Sens., 32, 787-813, https://doi.org/10.1080/01431161.2010.517791, 2011.

Gerasopoulos, E., Kouvarakis, G., Vrekoussis, M., Kanakidou, M., and Mihalopoulos, N.: Ozone variability in the marine boundary layer of the eastern Mediterranean based on 7-year observations, J. Geophys. Res.-Atmos., 110, D15309, https://doi.org/10.1029/2005JD005991, 2005.

Gerasopoulos, E., Kouvarakis, G., Vrekoussis, M., Donoussis, C., Mihalopoulos, N., and Kanakidou, M.: Photochemical ozone production in the Eastern Mediterranean, Atmos. Environ., 40, 3057-3069, https://doi.org/10.1016/j.atmosenv.2005.12.061, 2006.

Glaser, E., Dagan, N., Furer, O., Gamliel, M., Yogev, A., Fastig, S., Dayan, U., and Benayahu, Y.: A comparison of balloon soundings and lidar scans for measuring the height of the turbulent mixed-layer at a coastal site in Israel, Water Sci. Technol., 27, 271-278, 1993.

Gryning, S. E.: The Oresund experiment - A Nordic mesoscale dispersion experiment over a land-water-land area, B. Am. Meteorol. Soc., 66, 1403-1407, https://doi.org/10.1175/15200477(1985)066<1403:TENMDE>2.0.CO;2, 1985.

Halevy, G. and Steinberger, E. H.: Inland penetration of the summer inversion from the Mediterranean coast in Israel, Israel J. Earth Sci., 23, 47-54, 1974.

Harpaz, T., Ziv, B., Saaroni, H., and Beja, E.: Extreme summer temperatures in the East Mediterranean - dynamical analysis, Int. J Climatol., 34, 849-862, https://doi.org/10.1002/joc.3727, 2014.

Harris, J. M.: The GMCC Atmospheric Trajectory Program, NOAA Tech. Memo. ERL-ARL-116, Air Resources Laboratory, Silver Spring, MD, NOAA Environmental Research Laboratories, 30 pp., 1982.

Hein, R., Dameris, M., Schnadt, C., Land, C., Grewe, V., Köhler, I., Ponater, M., Sausen, R., B. Steil, B., Landgraf, J., and Brühl, C.: Results of an interactively coupled atmospheric chemistry - general circulation model: Comparison with observations, Ann. Geophys., 19, 435-457, https://doi.org/10.5194/angeo-19435-2001, 2001.

Holt, T. and Raman, S.: Marine boundary layer structure and circulation in the region of offshore development of a cyclone during GALE, Mon. Weather Rev., 118, 392-410, https://doi.org/10.1175/15200493(1990)118<0392:MBLSAC>2.0.CO;2, 1990.

Holtslag, A. A. M. and Van Ulden, A. P.: A simple scheme for daytime estimates of the surface fluxes from routine weather data, J. Clim. Appl. Meteorol., 22, 517-529, https://doi.org/10.1175/15200450(1983)022<0517:ASSFDE>2.0.CO;2, 1983. 
Hourdin, F., Musat, I., Bony, S., Braconnot, P., Codron, F., Dufresne, J. L., Fairhead, L., Filiberti, M. A., Friedlingstein, P., Grandpeix, J. Y., Krinner, G., LeVan, P., Li, Z. X., and Lott, F.: The LMDZ4 general circulation model: climate performance and sensitivity to parametrized physics with emphasis on tropical convection, Clim. Dynam., 27, 787-813, https://doi.org/10.1007/s00382-006-0158-0, 2006.

İm, U., Tayan, M., and Yenigün, O.: Interaction patterns of major photochemical pollutants in Istanbul, Turkey, Atmos. Res., 89, 382-390, https://doi.org/10.1016/j.atmosres.2008.03.015, 2008.

Im, U. and Kanakidou, M.: Impacts of East Mediterranean megacity emissions on air quality, Atmos. Chem. Phys., 12, 6335-6355, https://doi.org/10.5194/acp-12-6335-2012, 2012.

James, P., Stohl, A., Forster, C., Eckhardt, S., Seibert, P., and Frank, A.: A 15-year climatology of stratosphere-troposphere exchange with a Lagrangian particle dispersion model, 2, Mean climate and seasonal variability, J. Geophys. Res.-Atmos., 108, 8522, https://doi.org/10.1029/2002JD002639, 2003.

Kalthoff, N., Binder, H. J., Kossman, M., Vogtlin, R., Corsmeier, U., Fiedler, F., and Schlager, H.: Temporal evolution and spatial variation of the boundary layer over complex terrain, Atmos. Environ., 32, 1179-1194, https://doi.org/10.1016/S13522310(97)00193-3, 1998.

Kanakidou, M., Mihalopoulos, N., Kindap, T., Im, U., Vrekoussis, M., Gerasopoulos, E., Dermitzaki, E., Unal, A., Koçak, M., Markakis, K., Melas, D., Kouvarakis, G., Youssef, A. F., Richter, A., Hatzianastassiou, N., Hilboll, A., Ebojie, F., Wittrock, F., von Savigny, C., Burrows, J. P., LadstaetterWeissenmayer, A., and Moubasher, H.: Megacities as hot spots of air pollution in the East Mediterranean, Atmos. Environ., 45, 1223-1235, https://doi.org/10.1016/j.atmosenv.2010.11.048, 2011.

Karnieli, A., Derimian, Y., Indoitu, R., Panov, N., Levy, R. C., Remer, L. A., Maenhaut, W., and Holben, B. N.: Temporal trend in anthropogenic sulfur aerosol transport from central and eastern Europe to Israel, J. Geophys. Res.-Atmos., 114, D00D19, https://doi.org/10.1029/2009JD011870, 2009.

Kassomenos, P., Kotroni, V., and Kallos, G.: Analysis of climatological and air quality observations from greater Athens area, Atmos. Environ., 29, 3671-3688, https://doi.org/10.1016/13522310(94)00358-R, 1995.

Katsoulis, B. D.: The potential for long-range transport of air-pollutants into Greece: a climatological analysis, Sci. Total Environ., 231, 101-113, https://doi.org/10.1016/S00489697(99)00100-X, 1999.

Kleanthous, S., Vrekoussis, M., Mihalopoulos, N., Kalabokas, P., and Lelieveld, J.: On the temporal and spatial variation of ozone in Cyprus, Sci. Total Environ., 476-477, 677-687, https://doi.org/10.1016/j.scitotenv.2013.12.101, 2014.

Kley, D.: Tropospheric chemistry and transport, Science, 276, 1043-1045, https://doi.org/10.1126/science.276.5315.1043, 1997.

Koch, J. and Dayan, U.: A synoptic analysis of the meteorological conditions affecting dispersion of pollutants emitted from tall stacks in the coastal plain of Israel, Atmos. Environ., 26, $2537-$ 2543, https://doi.org/10.1016/0960-1686(92)90105-T, 1992.

Koulouri, E., Saarikoski, S., Theodosi, C., Markaki, Z., Gerasopoulos, E., Kouvarakis, G., Mäkela, T., Hillamo, R., and Mihalopoulos, N.: Chemical composition and sources of fine and coarse aerosol particles in the Eastern Mediterranean, Atmos. Environ., 42, 6542-6550, https://doi.org/10.1016/j.atmosenv.2008.04.010, 2008.

Kourtidis, K., Cerefos, C., Rapsomanikis, S., Simeonov, C., Balis, D., Perros, P. E., Thompson, A. M., Witte, J., Calpini, B., Sharobiem, W. M., Papayannis, A., Mihalopoulos, N., and Draku, R.: Regional levels of ozone in the troposphere over eastern Mediterranean, J. Geophys. Res.-Atmos., 107, 8140, https://doi.org/10.1029/2000JD000140, 2002.

Kouvarakis, G., Tsigaridis, K., Kanakidou, M., and Mihalopoulos, N.: Temporal variations of surface regional background ozone over Crete Island in southeast Mediterranean, J. Geophys. Res.-Atmos., 105, 4399-4407, 2000.

Kouvarakis, G., Vrekoussis, M., Mihalopoulos, N., Kourtidis, K., Rappenglueck, B., Gerasopoulos, E., and Zerefos, C.: Spatial and temporal variability of tropospheric ozone $\left(\mathrm{O}_{3}\right)$ in the boundary layer above the Aegean Sea (eastern Mediterranean), J. Geophys. Res.-Atmos., 107, 8137, https://doi.org/10.1029/2000JD000081, 2002.

Kubilay, N.: The composition of atmospheric aerosol over the Eastern Mediterranean; sources and temporal variability, $\mathrm{PhD}$ Thesis, Middle East Technical University, Ankara, Turkey, 1996.

Kuwagata, T., Masuko, N., Sumioka, M., and Kondo, J.: The daytime PBL heating process over complex terrain in central Japan under fair and calm weather conditions. Part II: Regional heat budget, convective boundary layer and surface moisture availability, J. Meteorol. Soc. Jpn., 68, 639-650, https://doi.org/10.2151/jmsj1965.68.6_639, 1990.

Lammel, G. and Cape, J. N.: Nitrous acid and nitrite atmosphere, Chem. Soc. Rev., 25, 361-369, 1996.

Langenfelds, R. L., Francey, R. G., Pak, B. C., Steele, L. P., Lloyd, J., Trudinger, C. M., and Allison, C. E.: Interannual growth rate variations and atmospheric $\mathrm{CO}_{2}$ and its $\delta^{13} \mathrm{C}, \mathrm{H}_{2}, \mathrm{CH}_{4}$ and $\mathrm{CO}$ between 1992 and 1999 linked to biomass burning, Global Biogeochem. Cy., 16, 1048, 21-1-2122, https://doi.org/10.1029/2001GB001466, 2002.

Lawrence, M. G. and Crutzen, P. J.: Influence of $\mathrm{NO}_{x}$ emissions from ships on tropospheric photochemistry and climate, Nature, 402, 167-170, https://doi.org/10.1038/46013, 1999.

Lelieveld, J., Crutzen, P. J., and Dentener, F. J.: Changing concentration, lifetime and climate forcing of atmospheric methane, Tellus B, 50, 128-150, https://doi.org/10.1034/j.16000889.1998.t01-1-00002.x, 1998.

Lelieveld, J. and Dentener, F. J.: What controls tropospheric ozone?, J. Geophys. Res.-Atmos., 105, 3531-3551, https://doi.org/10.1029/1999JD901011, 2000.

Lelieveld, J., Berresheim, H., Borrmann, S., Crutzen, P. J., Dentener, F. J., Fischer, H., Feichter, J., Flatau, P. J., Heland, J., Holzinger, R., Korrmann, R., Lawrence, M. G., Levin, Z., Markowicz, K. M., Mihalopoulos, N., Minikin, A., Ramanathan, V., de Reus, M., Roelofs, G. J., Scheeren, H. A., Sciare, J., Schlager, H., Schultz, M., Siegmund, P., Steil, B., Stephanou, E. G., Stier, P., Traub, M., Warneke, C., Williams, J., and Ziereis, H.: Global air pollution crossroads over the Mediterranean, Science, 298, 794-799, https://doi.org/10.1126/science.1075457, 2002.

Lensky, I. M. and Dayan, U.: Continuous detection and characterization of the Sea Breeze in clear sky conditions using Me- 
teosat Second Generation, Atmos. Chem. Phys., 12, 6505-6513, https://doi.org/10.5194/acp-12-6505-2012, 2012.

Lensky, I. M. and Dayan, U.: Satellite observations of land surface temperature patterns induced by synoptic circulation, Int. J. Climatol., 35, 189-195, https://doi.org/10.1002/joc.3971, 2015.

Leventidou, E., Zanis, P., Balis, D., Giannakaki, E., Pytharoulis, I., and Amiridis, V.: Factors affecting the comparisons of planetary boundary layer height retrievals from CALIPSO, ECMWF and radiosondes over Thessaloniki, Greece, Atmos. Environ., 74, 360-366, https://doi.org/10.1016/j.atmosenv.2013.04.007, 2013.

Levy, I., Dayan, U., and Mahrer, I.: A 5-yr study of the coastal recirculation and its effect on air pollutants over the East Mediterranean region, J. Geophys. Res.-Atmos., 113, D16121, https://doi.org/10.1029/2007JD009529, 2008.

Lieman, R. and Alpert, P.: Investigation of the planetary boundary layer height variations over complex terrain, Bound.-Lay. Meteorol., 62, 129-142, https://doi.org/10.1007/BF00705550, 1993.

Liu, J. J., Jones, D. B. A., Worden, J. R., Noone, D., Parrington, M., and Kar, J.: Analysis of the summertime buildup of tropospheric ozone abundances over the Middle East and NorthAfrica as observed by the tropospheric emission spectrometer instrument, J. Geophys. Res.-Atmos., 114, D05304, https://doi.org/10.1029/2008JD010993, 2009.

Luria, M., Peleg, M., Sharf, G., Alper-Siman Tov, D., Spitz, N., Ben Ami, Y., Gawii, Z., Lifschitz, B., Yitzchaki, A., and Seter, I.: Atmospheric sulfur over the east Mediterranean region, J. Geophys. Res.-Atmos., 101, 25917-25930, https://doi.org/10.1029/96JD01579, 1996.

Mallet, M., Dulac, F., Formenti, P., Nabat, P., Sciare, J., Roberts, G., Pelon, J., Ancellet, G., Tanré, D., Parol, F., Denjean, C., Brogniez, G., di Sarra, A., Alados-Arboledas, L., Arndt, J., Auriol, F., Blarel, L., Bourrianne, T., Chazette, P., Chevaillier, S., Claeys, M., D’Anna, B., Derimian, Y., Desboeufs, K., Di Iorio, T., Doussin, J.-F., Durand, P., Féron, A., Freney, E., Gaimoz, C., Goloub, P., Gómez-Amo, J. L., Granados-Muñoz, M. J., Grand, N., Hamonou, E., Jankowiak, I., Jeannot, M., Léon, J.-F., Maillé, M., Mailler, S., Meloni, D., Menut, L., Momboisse, G., Nicolas, J., Podvin, T., Pont, V., Rea, G., Renard, J.-B., Roblou, L., Schepanski, K., Schwarzenboeck, A., Sellegri, K., Sicard, M., Solmon, F., Somot, S., Torres, B., Totems, J., Triquet, S., Verdier, N., Verwaerde, C., Waquet, F., Wenger, J., and Zapf, P.: Overview of the Chemistry-Aerosol Mediterranean Experiment/Aerosol Direct Radiative Forcing on the Mediterranean Climate (ChArMEx/ADRIMED) summer 2013 campaign, Atmos. Chem. Phys., 16, 455-504, https://doi.org/10.5194/acp-16455-2016, 2016.

Marmer, E. and Langmann, B.: Impact of ship emissions on the Mediterranean summertime pollution and climate: a regional model study, Atmos. Environ., 39, 4659-4669, https://doi.org/10.1016/j.atmosenv.2005.04.014, 2005.

Marmer, E., Dentener, F., Aardenne, J. v., Cavalli, F., Vignati, E., Velchev, K., Hjorth, J., Boersma, F., Vinken, G., Mihalopoulos, N., and Raes, F.: What can we learn about ship emission inventories from measurements of air pollutants over the Mediterranean Sea?, Atmos. Chem. Phys., 9, 6815-6831, https://doi.org/10.5194/acp-9-6815-2009, 2009.

Matvev, V., Dayan, U., Tass, I., and Peleg, M.: Atmospheric sulfur flux rates to and from Israel, Sci. Total Environ., 291, 143-154, https://doi.org/10.1016/S0048-9697(01)01089-0, 2002.
McElroy, J. L. and Smith, T. B.: Lidar description of mixing-layer thickness characteristics in a complex terrain/coastal environment, J. Appl. Meteorol., $\quad 30, \quad 585-597, \quad$ https://doi.org/10.1175/15200450(1991)030<0585:LDOMLT>2.0.CO;2, 1991.

Meagher, J. F., Stockburger, L., Bonanno, R. J., Bailey, E. M., and Luria, M.: Atmospheric oxidation of flue-gases from coal-fired power-plants-A comparison between conventional and scrubbed plumes, Atmos. Environ., 15, 749-762, https://doi.org/10.1016/0004-6981(81)90279-1, 1981.

Michou, M., Saint-Martin, D., Teyssèdre, H., Alias, A., Karcher, F., Olivié, D., Voldoire, A., Josse, B., Peuch, V.-H., Clark, H., Lee, J. N., and Chéroux, F.: A new version of the CNRM ChemistryClimate Model, CNRM-CCM: description and improvements from the CCMVal-2 simulations, Geosci. Model Dev., 4, 873900, https://doi.org/10.5194/gmd-4-873-2011, 2011.

Mihalopoulos, N., Stephanou, E., Kanakidou, M., Pilitsidis, S., and Bousquet, Q.: Tropospheric aerosol ionic composition in the Eastern Mediterranean region, Tellus B, 49, 314-326, 1997.

Mihalopoulos, N., Kerminen, V. M., Kanakidou, M., Berresheim, H., and Sciare, J.: Formation of particulate sulfur species (sulfate and methanesulfonate) during summer over the Eastern Mediterranean: a modelling approach, Atmos. Environ., 41, 6860-6871, https://doi.org/10.1016/j.atmosenv.2007.04.039, 2007.

Miller, S. T., Keim, B. D., Talbot, R. W., and Mao, H.: Sea breeze: structure, forecasting, and impacts, Rev. Geophys., 41, 1011, https://doi.org/10.1029/2003RG000124, 2003.

Moulin, C., Lambert, C. E., Dayan, U., Masson, V., Ramonet, M., Bousquet, P., Legrand, M., Balkanski, Y. J., Guelle, W., Marticorena, B., Bergametti, G., and Dulac, F.: Satellite climatology of African dust transport in the Mediterranean atmosphere, J. Geophys. Res.-Atmos., 103, $13137-$ 13144, https://doi.org/10.1029/98JD00171, 1998.

Myriokefalitakis, S., Daskalakis, N., Fanourgakis, G. S., Voulgarakis, A., Krol, M. C., Aan de Brugh, J. M. J., and Kanakidou, M.: Ozone and carbon monoxide budgets over the Eastern Mediterranean, Sci. Total Environ., 563-564, 40-52, https://doi.org/10.1016/j.scitotenv.2016.04.061, 2016.

Nabat, P., Somot, S., Mallet, M., Chiapello, I., Morcrette, J. J., Solmon, F., Szopa, S., Dulac, F., Collins, W., Ghan, S., Horowitz, L. W., Lamarque, J. F., Lee, Y. H., Naik, V., Nagashima, T., Shindell, D., and Skeie, R.: A 4-D climatology (1979-2009) of the monthly tropospheric aerosol optical depth distribution over the Mediterranean region from a comparative evaluation and blending of remote sensing and model products, Atmos. Meas. Tech., 6, 1287-1314, https://doi.org/10.5194/amt-6-1287-2013, 2013.

Neumann, J.: Diurnal variation of the subsidence inversion and radio wave propagation phenomena over the coastal area of Israel, Series A, Meteorol. Notes, 16, Israel Meteorological Service, Jerusalem, 12 pp., 1952.

Nirel, R. and Dayan, U.: On the ratio of sulfur dioxide to nitrogen oxides as an indicator of air pollution sources, J. Appl. Meteorol., 40, 1209-1222, https://doi.org/10.1175/15200450(2001)040<1209:OTROSD>2.0.CO;2, 2001.

Novelli, P. C., Steele, L. P., and Tans, P. P.: Mixing ratios of carbon-monoxide in the troposphere, J. Geophys. Res.-Atmos., 97, 20731-20750, https://doi.org/10.1029/92JD02010, 1992. 
Özden, O., Döğeroğlu, T., and Kara, S.: Assessment of ambient air quality in Eskişehir, Turkey, Environ. Int., 34, 678-687, https://doi.org/10.1016/j.envint.2007.12.016, 2008.

Peleg, M., Luria, M., Setter, I., Perner, D., and Russel, P.: Ozone levels in central Israel, Isr. J. Chem., 34, 375-386, https://doi.org/10.1002/ijch.199400041, 1994.

Pielke, R. A. and Stocker, R. A.: A procedure to estimate worstcase air quality in complex terrain, Environ. Int., 17, 559-574, https://doi.org/10.1016/0160-4120(91)90168-P, 1991.

Ranmar, D. O., Matveev, V., Dayan, U., Peleg, M., Kaplan, J., Gertler, A. W., Luria, M., Kallos, G., Katsafados, P., and Mahrer, Y.: Impact of coastal transportation emissions on inland air pollution over Israel: utilizing numerical simulations, airborne measurements and synoptic analyses, J. Geophys. Res.-Atmos., 107, 4331, https://doi.org/10.1029/2001JD000808, 2002.

Ricaud, P., Sič, B., El Amraoui, L., Attié, J.-L., Zbinden, R., Huszar, P., Szopa, S., Parmentier, J., Jaidan, N., Michou, M., Abida, R., Carminati, F., Hauglustaine, D., August, T., Warner, J., Imasu, R., Saitoh, N., and Peuch, V.-H.: Impact of the Asian monsoon anticyclone on the variability of mid-to-upper tropospheric methane above the Mediterranean Basin, Atmos. Chem. Phys., 14, 1142711446, https://doi.org/10.5194/acp-14-11427-2014, 2014.

Ricaud, P., Zbinden, R., Catoire, V., Brocchi, V., Dulac, F., Hamonou, E., Canonici, J.-C., El Amraoui, L., Massart, S., Piguet, B., Dayan, U., Nabat, P., Sciare, J., Ramonet, M., Delmotte, M., di Sarra, A., Sferlazzo, D., Di Iorio, T., Piacentino, S., Cristofanelli, P., Mihalopoulos, N., Kouvarakis, G., Pikridas, M., Savvides, C., Mamouri, R., Nisantzi, A., Hadjimitsis, D., Attié, J.-L., Ferré, H., Theron, P., Kangah, Y., Jaidan, N., Guth, J., Jacquet, P., Chevrier, S., Robert, C., Bourdon, A., Bourdinot, J.F., Etienne, J.-C., Krysztofiak, G., and Theron, P.: The GLAM Airborne Campaign over the Mediterranean Basin, B. Am. Meteorol. Soc., https://doi.org/10.1175/BAMS-D-16-0226.1, online first, 2017.

Riga-Karandinos, A. and Saitanis, C.: Comparative assessment of ambient air quality in two typical Mediterranean coastal cities in Greece, Chemosphere, 59, 1125-1136, https://doi.org/10.1016/j.chemosphere.2004.11.059, 2005.

Rindsberger, M.: Analysis of mixing depth over Tel-Aviv, Israel, J. Earth Sci., 23, 13-17, 1974.

Rindsberger, M.: Air pollution potential in greater Tel-Aviv area, Israel, J. Earth Sci., 25, 127-132, 1976.

Rodwell, M. J. and Hoskins, B. J.: Monsoons and the dynamics of deserts, Q. J. Roy. Meteor. Soc., 122, 1385-1404, https://doi.org/10.1002/qj.49712253408, 1996.

Roelofs, G. J., Scheeren, H. A., Heland, J., Ziereis, H., and Lelieveld, J.: A model study of ozone in the eastern Mediterranean free troposphere during MINOS (August 2001), Atmos. Chem. Phys., 3, 1199-1210, https://doi.org/10.5194/acp-3-11992003, 2003.

Rudich, Y., Kaufman, J., Dayan, U., Hongbin, Y., and Kleidman, R. G.: Estimation of transboundary transport of pollution aerosols by remote sensing in the eastern Mediterranean, J. Geophys. Res.-Atmos., 113, D14S13, https://doi.org/10.1029/2007JD009601, 2008.

Safieddine, S., Boynard, A., Coheur, P.-F., Hurtmans, D., Pfister, G., Quennehen, B., Thomas, J. L., Raut, J.-C., Law, K. S., Klimont, Z., Hadji-Lazaro, J., George, M., and Clerbaux, C.:
Summertime tropospheric ozone assessment over the Mediterranean region using the thermal infrared IASI/MetOp sounder and the WRF-Chem model, Atmos. Chem. Phys., 14, 1011910131, https://doi.org/10.5194/acp-14-10119-2014, 2014.

Saliba, N. A., Moussa, S., Salame, H., and El-Fadel, M.: Variation of selected air quality indicators over the city of Beirut, Lebanon: assessment of emission sources, Atmos. Environ., 40, 32633268, https://doi.org/10.1016/j.atmosenv.2006.01.054, 2006.

Sciare, J., Bardouki, H., Moulin, C., and Mihalopoulos, N.: Aerosol sources and their contribution to the chemical composition of aerosols in the Eastern Mediterranean Sea during summertime, Atmos. Chem. Phys., 3, 291-302, https://doi.org/10.5194/acp-3291-2003, 2003.

Sciare, J., Oikonomou, K., Cachier, H., Mihalopoulos, N., Andreae, M. O., Maenhaut, W., and Sarda-Estève, R.: Aerosol mass closure and reconstruction of the light scattering coefficient over the Eastern Mediterranean Sea during the MINOS campaign, Atmos. Chem. Phys., 5, 2253-2265, https://doi.org/10.5194/acp-5-22532005, 2005.

Schneising, O., Buchwitz, M., Burrows, J. P., Bovensmann, H., Bergamaschi, P., and Peters, W.: Three years of greenhouse gas column-averaged dry air mole fractions retrieved from satellite - Part 2: Methane, Atmos. Chem. Phys., 9, 443-465, https://doi.org/10.5194/acp-9-443-2009, 2009.

Seinfeld, J. H.: Urban air pollution: state of the science, Science, 243, 745-752, https://doi.org/10.1126/science.243.4892.745, 1989.

Sič, B., El Amraoui, L., Piacentini, A., Marécal, V., Emili, E., Cariolle, D., Prather, M., and Attié, J.-L.: Aerosol data assimilation in the chemical transport model MOCAGE during the TRAQA/ChArMEx campaign: aerosol optical depth, Atmos. Meas. Tech., 9, 5535-5554, https://doi.org/10.5194/amt-9-55352016, 2016.

Sinclair, V. A., Belcher, S. E., and Gray, S. L.: Synoptic controls on boundary-layer characteristics, Bound.-Layer Meteorol., 134, 387-409, https://doi.org/10.1007/s10546-009-9455-6, 2010.

Sprenger, M. and Wernli, H.: A northern hemispheric climatology of cross-tropopause exchange for the ERA15 time period (1979-1993), J. Geophys. Res.-Atmos., 108, 8521, https://doi.org/10.1029/2002JD002636, 2003.

Stohl, A., James, P., Forster, C., Spinchtinger, N., Marenco, A., Thouret, V., and Smit, H. G. J.: An extension of MOZAIC ozone climatologies using trajectory statistics, J. Geophys. Res.-Atmos., 106, 27757-27768, https://doi.org/10.1029/2001JD000749, 2001.

Stunder, M. and Sethuraman, S.: A comparative evaluation of the coastal internal boundary layer height, Bound.-Lay. Meteorol. 32, 177-204, https://doi.org/10.1007/BF00120934, 1985.

Svensson, G.: A numerical model for chemical and meteorological processes in the atmospheric boundary layer. Part II: A case study of the air quality situation in Athens, Greece, J. Appl. Meteorol., 35, 955-973, https://doi.org/10.1175/15200450(1996)035<0955:ANMFCA>2.0.CO;2, 1996.

Teyssèdre, H., Michou, M., Clark, H. L., Josse, B., Karcher, F., Olivié, D., Peuch, V.-H., Saint-Martin, D., Cariolle, D., Attié, J.-L., Nédélec, P., Ricaud, P., Thouret, V., van der A, R. J., VolzThomas, A., and Chéroux, F.: A new tropospheric and stratospheric Chemistry and Transport Model MOCAGE-Climat for multi-year studies: evaluation of the present-day climatology and 
sensitivity to surface processes, Atmos. Chem. Phys., 7, 58155860, https://doi.org/10.5194/acp-7-5815-2007, 2007.

Tombrou, M., Bossioli, E., Kalogiros, J., Allan, J. D., Bacak, A., Biskos, G., Coe, H., Dandou, A., Kouvarakis, G., Mihalopoulos, N., Percival, C. J., Protonotariou, A. P., and Szabó-Takács, B.: Physical and chemical processes of air masses in the Aegean Sea during Etesians: Aegean-GAME airborne campaign, Sci. Total Environ., 506-507, 201-216, https://doi.org/10.1016/j.scitotenv.2014.10.098, 2015.

Traub, M., Fischer, H., de Reus, M., Kormann, R., Heland, H., Ziereis, H., Schlager, H., Holzinger, R., Williams, J., Warneke, C., de Gouw, J., and Lelieveld, J.: Chemical characteristics assigned to trajectory clusters during the MINOS campaign, Atmos. Chem. Phys., 3, 459-468, https://doi.org/10.5194/acp-3459-2003, 2003.

Tsitouridou, R. and Samara, C.: First results of acidic and alkaline constituents determination in air particulates of Thessaloniki, Greece, Atmos. Environ., 27, 313-319, 1993.

Tyrlis, E. and Lelieveld, J.: Climatology and dynamics of the summer Etesian winds over the Eastern Mediterranean, J. Atmos. Sci., 70, 3374-3396, https://doi.org/10.1175/JAS-D-13035, 2013

Tyrlis, E., Lelieveld, J., and Steil, B.: The summer circulation over the eastern Mediterranean, and the Middle East: influence of the South Asian monsoon, Clim. Dynam., 40, 1103-1123, https://doi.org/10.1007/s00382-012-1528-4, 2013.

Tyrlis, E., Škerlak, B., Sprenger, M., Wernli, H., Zittis, G., and Lelieveld, J.: On the linkage between the Asian summer monsoon and tropopause fold activity over the eastern Mediterranean and the Middle East, J. Geophys. Res.-Atmos., 119, 3202-3221, https://doi.org/10.1002/2013JD021113, 2014.

Večeřa, Z., Mikuška, P., Smolík, J., Eleftheriadis, K., Bryant, C., Colbeck, I., and Lazaridis, M.: Shipboard measurements of nitrogen dioxide, nitrous acid, nitric acid and ozone in the eastern Mediterranean Sea, Water Air Soil Poll. Focus, 8, 117-125, https://doi.org/10.1007/s11267-007-9133-y, 2008.

Vinken, G. C. M., Boersma, K. F., van Donkelaar, A., and Zhang, L.: Constraints on ship $\mathrm{NO}_{x}$ emissions in Europe using GEOS-Chem and OMI satellite $\mathrm{NO}_{2}$ observations, Atmos. Chem. Phys., 14, 1353-1369, https://doi.org/10.5194/acp-141353-2014, 2014.

Voulgarakis, A., Savage, N. H., Wild, O., Braesicke, P., Young, P. J., Carver, G. D., and Pyle, J. A.: Interannual variability of tropospheric composition: the influence of changes in emissions, meteorology and clouds, Atmos. Chem. Phys., 10, 2491-2506, https://doi.org/10.5194/acp-10-2491-2010, 2010.
Wanger, A., Peleg, M., Sharf, G., Mahrer, Y., Dayan, U., Kallos, G., Kotroni, V., Lagouvardos, K., Varinou, M., Papadopoulos, A., and Luria, M.: Some observational and modelling evidence of long-range transport of air pollutants from Europe towards the Israeli coast, J. Geophys. Res.-Atmos., 105, 71777186, https://doi.org/10.1029/1999JD901060, 2000.

Yuval, Dubowski, Y., and Broday, D. M.: Allocation of routinely monitored mixing ratios of nitrogen oxides to their sources, Environ. Sci. Technol., 41, 7215-7221, https://doi.org/10.1021/es0702317, 2007.

Zanis, P., Hadjinicolaou, P., Pozzer, A., Tyrlis, E., Dafka, S., Mihalopoulos, N., and Lelieveld, J.: Summertime free-tropospheric ozone pool over the eastern Mediterranean/Middle East, Atmos. Chem. Phys., 14, 115-132, https://doi.org/10.5194/acp-14-1152014, 2014.

Zbinden, R. M., Thouret, V., Ricaud, P., Carminati, F., Cammas, J.-P., and Nédélec, P.: Climatology of pure tropospheric profiles and column contents of ozone and carbon monoxide using MOZAIC in the mid-northern latitudes $\left(24^{\circ} \mathrm{N}\right.$ to $\left.50^{\circ} \mathrm{N}\right)$ from 1994 to 2009, Atmos. Chem. Phys., 13, 12363-12388, https://doi.org/10.5194/acp-13-12363-2013, 2013.

Zbinden, R. M., Ricaud, P., Catoire, V., Brocchi, V., Massart, S., El Amraoui, L., Attie, J. L., Nabat, P., Dulac, F., Hamonou, E., Dayan, U., Piguet, B., and the SAFIRE team: Processes affecting the tropospheric chemical variability over the Mediterranean Basin: results from the summer GLAM campaign, Atmospheric Processes in the Mediterranean (APM 2016): A joint ACTRIS - BACCHUS - CHArMEx Int. Workshop, 17-21 October 2016, available at: http://www.cyi.ac.cy/index. php/apm-workshop-2016-home.html (last access: 6 November 2017), 2016.

Zhang, J. S. and Rao, S. T.: The role of vertical mixing in the temporal evolution of ground-level ozone concentrations, J. Appl. Meteorol., 38, 1674-1691, https://doi.org/10.1175/15200450(1999)038<1674:TROVMI>2.0.CO;2, 1999.

Ziemke, J. R., Chandra, S., Labow, G. J., Bhartia, P. K., Froidevaux, L., and Witte, J. C.: A global climatology of tropospheric and stratospheric ozone derived from Aura OMI and MLS measurements, Atmos. Chem. Phys., 11, 9237-9251, https://doi.org/10.5194/acp-11-9237-2011, 2011.

Ziv, B., Saaroni, H., and Alpert, P.: The factors governing the summer regime of the eastern Mediterranean, Int. J. Climatol., 24 1859-1871, https://doi.org/10.1002/joc.1113, 2004. 